\title{
EOSINOFILIA TECIDUAL COMO FATOR DE PROGNÓSTICO EM CARCINOMAS ESPINOCELULARES DE BOCA
}

\author{
REGINA GARCIA DORTA
}

Dissertação apresentada à Faculdade de Odontologia de Bauru da Universidade de São Paulo, como parte dos requisitos para obtenção do título de Mestre em Odontologia, área de Patologia Bucal.

(Edição Revisada)

\section{BAURU}




\title{
EOSINOFILIA TECIDUAL COMO FATOR DE PROGNÓSTICO EM CARCINOMAS ESPINOCELULARES DE BOCA
}

\author{
REGINA GARCIA DORTA
}

\begin{abstract}
Dissertação apresentada à Faculdade de Odontologia de Bauru da Universidade de São Paulo, como parte dos requisitos para obtenção do título de Mestre em Odontologia, área de Patologia Bucal.
\end{abstract}

(Edição Revisada)

Orientadora: Prof. ${ }^{a}$ Dr. ${ }^{a}$ Denise Tostes Oliveira

\section{BAURU}




\begin{tabular}{|c|c|}
\hline \multirow{4}{*}{ D739e } & Dorta, Regina Garcia \\
\hline & $\begin{array}{l}\text { Eosinofilia tecidual como fator de prognóstico em carcinomas } \\
\text { espinocelulares de boca. / Regina Garcia Dorta. -- Bauru, } 2000 . \\
\text { xix, } 110 \text { p.:il.; } 30 \mathrm{~cm} .\end{array}$ \\
\hline & $\begin{array}{l}\text { Dissertação. (Mestrado). - Faculdade de Odontologia de Bauru. } \\
\text { Universidade de São Paulo }\end{array}$ \\
\hline & Orientadora: Prof. ${ }^{a}$ Dr. ${ }^{a}$ Denise Tostes Oliveira \\
\hline
\end{tabular}

Autorizo, exclusivamente para fins acadêmicos e científicos, a reprodução total ou parcial desta dissertação, por processos fotocopiadores e/ou meios eletrônicos.

Assinatura do autor:

Data: $04 / 10 / 2000$ 


\section{DADOS CURRICULARES}

\section{REGINA GARCIA DORTA}

14 de novembro de 1972

Bauru - SP

$1991-1994$

$1995-1996$

1997

$1998-2000$

Associação
Nascimento

Curso de Graduação em Odontologia - Faculdade de Odontologia de Bauru - USP

Curso de Aprimoramento em Odontologia Hospitalar - Hospital das Clínicas - Faculdade de Medicina, USP - São Paulo

Cirurgiã-dentista - Prefeitura Municipal de Campinas

Curso de Mestrado em Patologia Bucal Faculdade de Odontologia de Bauru, USP

SOBE - Sociedade Brasileira de Estomatologia 
"Mais vale o impreciso que embala, do que o certo que basta. Porque o basta acaba onde basta. E onde acaba não basta. E nada que se pareça com o que basta devia ser o sentido da vida” 


\section{DEDICATÓRIA}

À minha querida família

Pelo amor e apoio constantes em todos os momentos da minha vida.

À minha orientadora e amiga,

Professora Doutora Denise Tostes Oliveira

Pela amizade,

Pela compreensão,

Pelo incentivo,

Pela paciência,

Pela coragem,

Pela força,

Pelos ensinamentos,

Pelo exemplo.

A você devo a realização de um sonho.

Muito obrigada!! 


\section{Aos pacientes}

O meu profundo respeito e admiração por aqueles que nos mostram o valor de cada momento da vida, de um simples gesto de carinho, da solidariedade, da luta, da ESPERANÇA....

O meu agradecimento àqueles que, talvez por um desígnio maior, nos provam o quanto somos iguais... mais iguais do que podemos imaginar.

Que Deus os abençoe! 


\title{
AGRADECIMENTOS ESPECIAIS
}

\author{
Ao Dr. Gilles Landman,
}

por ter tornado possível pelo seu interesse, competência, experiência e incentivo constante, a realização deste trabalho em conjunto com uma instituição idônea como o Hospital do Câncer, o que tem até hoje nos proporcionado um grande enriquecimento científico e humano.

\section{Ao Dr. Luiz Paulo Kowalski,}

que por meio da sua experiência, competência e interesse, prestou grande colaboração no desenvolvimento deste trabalho. Agradecemos também pelo incentivo e pelo voto de confiança em nós depositado. 


\section{AGRADECIMENTOS}

Aos professores da Disciplina de Patologia da Faculdade de Odontologia de Bauru, Dr. ${ }^{a}$ Vanessa Soares Lara, Dr. Luís Antônio de Assis Taveira, Dr. Alberto Consolaro e, em especial à Dr. ${ }^{\text {a }}$ Denise Tostes Oliveira, pelo incentivo e pelos ensinamentos transmitidos desde o período de graduação.

À Prof. ${ }^{a}$ Dr. ${ }^{a}$ Maria do Rosário Dias de Oliveira Latorre e ao Prof. Dr. José Roberto Pereira Lauris, pela competência e inesgotável paciência na orientação estatística.

Aos funcionários da Disciplina de Patologia da Faculdade de Odontologia de Bauru, Bernadete, Cristina, Fatiminha e Sr. Valdir, pela amizade e pelos momentos agradáveis de convivência.

A todos os funcionários do Hospital do Câncer, em especial à Sra. Hirde Contesini, do Serviço de Arquivo Médico e ao funcionário Carlos Ferreira Nascimento, do Laboratório de Histologia do Instituto Ludwig de Pesquisa Sobre o Câncer.

À Andréa e Graziela, residentes do Hospital do Câncer, pelo carinho com que me acolheram.

Às meninas do mestrado, Fernandinha, Márcia, Marianne, Marizinha, Mônica e Renata, pela alegria de ter convivido e aprendido tantas lições de vida com vocês!

A todos os colegas de pós-graduação, pelos bons momentos compartilhados. 


\section{AGRADECIMENTOS INSTITUCIONAIS}

A todos os funcionários da Biblioteca e do setor de Pós-graduação da Faculdade de Odontologia de Bauru, USP, pela colaboração.

À Direção da Faculdade de Odontologia de Bauru, USP, na pessoa do Diretor, Professor Doutor Aymar Pavarini.

À Comissão de Pós-graduação da Faculdade de Odontologia de Bauru, USP, na pessoa do Presidente, Professor Doutor Luiz Fernando Pegoraro.

Ao Centro de Tratamento e Pesquisa Hospital do Câncer - São Paulo, na pessoa do Diretor Clínico, Dr. Daniel Deheinzelin.

À CAPES, pelo auxílio pecuniário. 


\section{SUMÁRIO}

LISTA DE FIGURAS

$\mathbf{x i i}$

LISTA DE TABELAS

xiii

LISTA DE ABREVIATURAS

XV

RESUMO $\quad$ xix

1 INTRODUÇÃO

2 REVISÃO DA LITERATURA 5

2.1 Morfologia dos eosinófilos 6

2.2 Desenvolvimento dos eosinófilos 8

2.3 Mediadores químicos derivados dos eosinófilos 9

2.4 Outros mediadores químicos produzidos pelos eosinófilos 12

2.5 Fatores Quimiotáticos para os eosinófilos 14

2.6 Ativação dos eosinófilos $\quad 15$

2.7 Receptores de superfície presentes nos eosinófilos 15

$\begin{array}{lll}2.8 & \text { Eosinofilia } & 18\end{array}$

2.9 Eosinofilia em câncer de cabeça e pescoço 20

$3 \quad$ PROPOSIÇÃO

4 MATERIAL E MÉTODOS $\quad 45$

4.1 População de estudo 46

4.2 Registro dos dados clínicos e microscópicos $\quad 47$

$\begin{array}{lll}4.3 & \text { Análise microscópica qualitativa } & 48\end{array}$

4.4 Análise microscópica quantitativa 48

4.5 Variáveis de estudo $\quad 50$

4.6 Análise estatística 52 
5 RESULTADOS $\quad 56$

5.1 Caracterização clínica e microscópica da população de estudo 57

5.1.1 Características clínicas $\quad 57$

5.1.2 Características microscópicas 63

5.2 Análise da associação entre a classificação da eosinofilia tecidual e as demais 73 variáveis de estudo

5.3 Comparação entre os métodos qualitativo e quantitativo de classificação da 77 eosinofilia tecidual

$\begin{array}{lll}5.4 & \text { Análise de sobrevida } & 78\end{array}$

6 DISCUSSÃO $\quad 84$

$\begin{array}{lll}7 & \text { CONCLUSÃO } & 97\end{array}$

REFERÊNCIAS BIBLIOGRÁFICAS 100

$\begin{array}{ll}\text { ABSTRACT } & 110\end{array}$ 


\section{LISTA DE FIGURAS}

FIGURA 1 - Formulário utilizado para a coleta dos dados clínicos e microscópicos relativos aos 125 pacientes portadores de carcinoma espinocelular de boca

FIGURA 2 - Eosinofilia tecidual presente no estroma e parênquima tumoral

FIGURA 3 - Presença de infiltração tumoral perineural e muscular

FIGURA 4 - Classificação da intensidade da eosinofilia tecidual segundo tercis do número de eosinófilos por milímetro quadrado obtidos nos 125 casos estudados

FIGURA 5 - Diferentes intensidades de infiltração dos carcinomas espinocelulares de boca por eosinófilos

FIGURA 6 - Diagrama de dispersão entre morfometria por área e morfometria por fração de volume (teste de correlação de Pearson)

FIGURA 7 - Associação entre infiltrado inflamatório mononuclear intenso e eosinofilia tecidual intensa em carcinomas espinocelulares de boca

FIGURA 8 - Presença dos eosinófilos com núcleo bilobulado e grânulos 75 citoplasmáticos fortemente corados pela eosina

FIGURA 9 - Influência da eosinofilia tecidual na sobrevida livre de doença em pacientes com carcinoma espinocelular de boca

FIGURA 10 - Influência da eosinofilia tecidual na sobrevida global em pacientes com carcinoma espinocelular de boca 


\section{LISTA DE TABELAS}

TABELA 1 - Número e porcentagem de pacientes acometidos por carcinoma espinocelular de boca, segundo características demográficas. Hospital do Câncer, São Paulo, 1970 a 1992

TABELA 2 - Número e porcentagem de pacientes acometidos por carcinoma espinocelular de boca, segundo fatores de risco e características clínicas dos pacientes. Hospital do Câncer, São Paulo, 1970 a 1992

TABELA 3 - Número e porcentagem de pacientes acometidos por carcinoma espinocelular de boca, segundo localização. Hospital do Câncer, São Paulo, 1970 a 1992

TABELA 4 - Número e porcentagem de pacientes acometidos por carcinoma espinocelular de boca, segundo características e estadiamento clínico tumorais. Hospital do Câncer, São Paulo, 1970 a 1992

TABELA 5 - Número e porcentagem de pacientes acometidos por carcinoma espinocelular de boca, segundo tratamento. Hospital do Câncer, São Paulo, 1970 a 1992

TABELA 6 - Número e porcentagem de pacientes acometidos por carcinoma espinocelular de boca, segundo distribuição, localização e intensidade do infiltrado inflamatório. Hospital do Câncer, São Paulo, 1970 a 1992

TABELA 7 - Número e porcentagem de pacientes acometidos por carcinoma espinocelular de boca, segundo morfologia tumoral. Hospital do Câncer, São Paulo, 1970 a 1992

TABELA 8 - Número e porcentagem de pacientes acometidos por carcinoma espinocelular de boca, segundo infiltração tumoral. Hospital do Câncer, São Paulo, 1970 a 1992 
TABELA 9 - Avaliação da associação entre classificação da eosinofilia tecidual e infiltrado inflamatório mononuclear (teste de associação pelo quiquadrado)

TABELA 10 - Avaliação da associação entre eosinofilia tecidual e localização do 76 infiltrado inflamatório eosinofílico (teste de associação pelo quiquadrado)

TABELA 11 - Avaliação da concordância entre o método qualitativo e quantitativo de classificação da eosinofilia tecidual (estatística Kappa)

TABELA 12 - Análise de sobrevida livre de doença. Porcentagem de sobrevida acumulada pela técnica de Kaplan-Meier

TABELA 13 - Análise de sobrevida global. Porcentagem de sobrevida acumulada pela técnica de Kaplan-Meier

TABELA 14 - Análise da eosinofilia tecidual por meio do modelo de Cox

TABELA 15 - Diferentes critérios utilizados para a classificação da eosinofilia 89 tecidual nos tumores malignos da região de cabeça e pescoço 


\section{LISTA DE ABREVIATURAS}

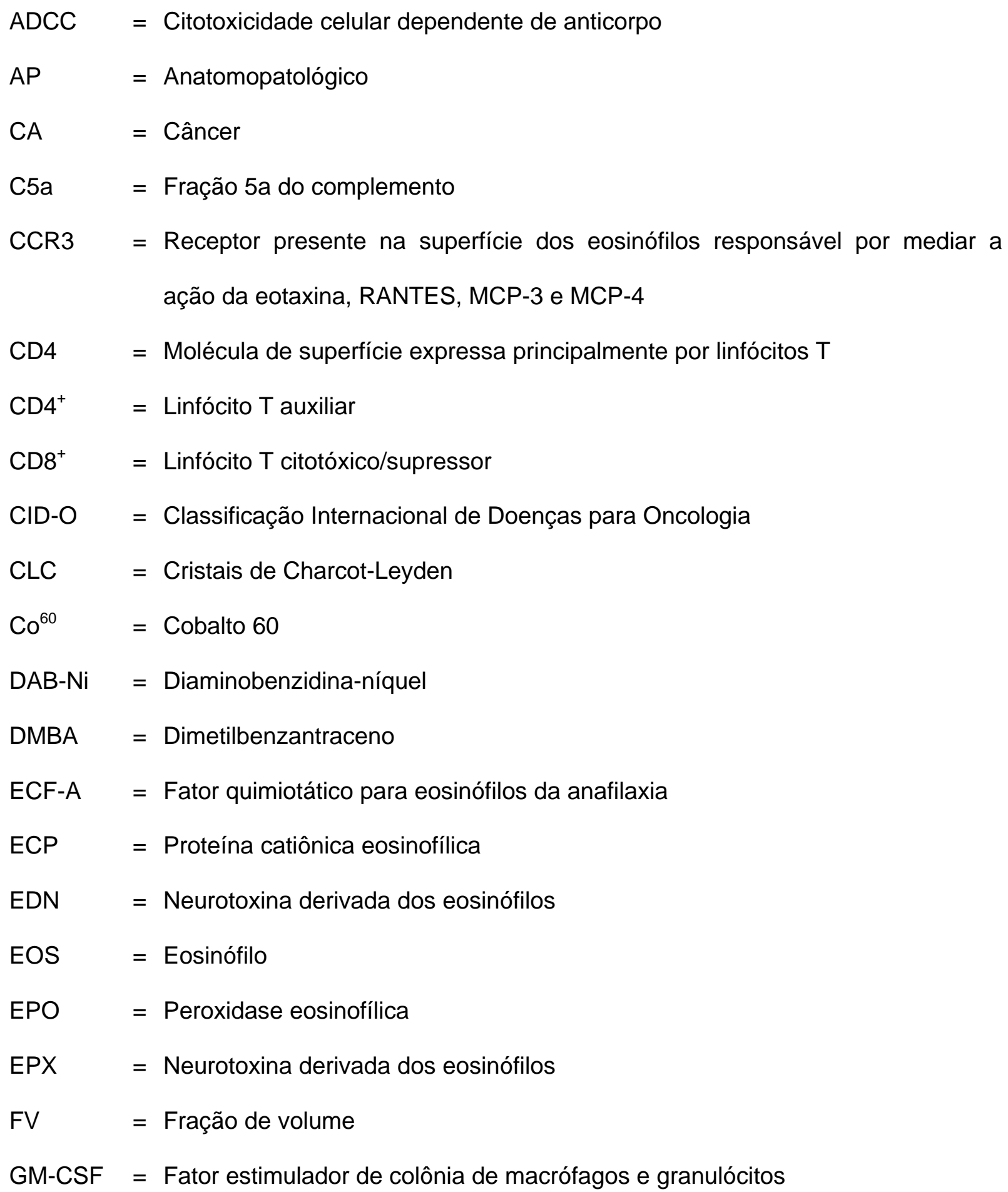




$$
\begin{aligned}
& \text { HE = Hematoxilina e eosina } \\
& \text { HETE = Ácido hidroxieicosatetraenóico } \\
& \text { HLA-DR = Subregião DR do antígeno leucocitário humano } \\
& \text { ICAM-1 = Molécula de adesão intercelular-1 } \\
& \lg \mathrm{A}=\text { Imunoglobulina } \mathrm{A} \\
& \lg \mathrm{E}=\text { Imunoglobulina } \mathrm{E} \\
& \lg \mathrm{G}=\text { Imunoglobulina } \mathrm{G} \\
& \text { IFN- } \alpha=\text { Interferon-alfa } \\
& \text { IFN- } \beta=\text { Interferon-beta } \\
& \text { IFN- } \gamma=\text { Interferon-gama } \\
& \mathrm{IL}-1 \alpha=\text { Interleucina- } 1 \text { alfa } \\
& \text { IL-2 = Interleucina-2 } \\
& \mathrm{IL}-3=\text { Interleucina-3 } \\
& \text { IL-4 = Interleucina-4 } \\
& \text { IL }-5=\text { Interleucina }-5 \\
& \text { IL-6 = Interleucina-6 } \\
& \text { IL-8 = Interleucina-8 } \\
& \text { INCA = Instituto Nacional de Câncer } \\
& \text { LCF } \quad=\text { Fator quimiotático para linfócitos } \\
& \text { LFA-1 = Antígeno funcional de leucócitos-1 } \\
& \mathrm{LTB}_{4} \quad=\text { Leucotrieno } \mathrm{B}_{4} \\
& \mathrm{LTC}_{4}=\text { Leucotrieno } \mathrm{C}_{4} \\
& \mathrm{LTD}_{4} \quad=\text { Leucotrieno } \mathrm{D}_{4} \\
& \mathrm{LTE}_{4} \quad=\text { Leucotrieno } \mathrm{E}_{4} \\
& \text { Mac-1 = Antígeno macrofágico-1 }
\end{aligned}
$$




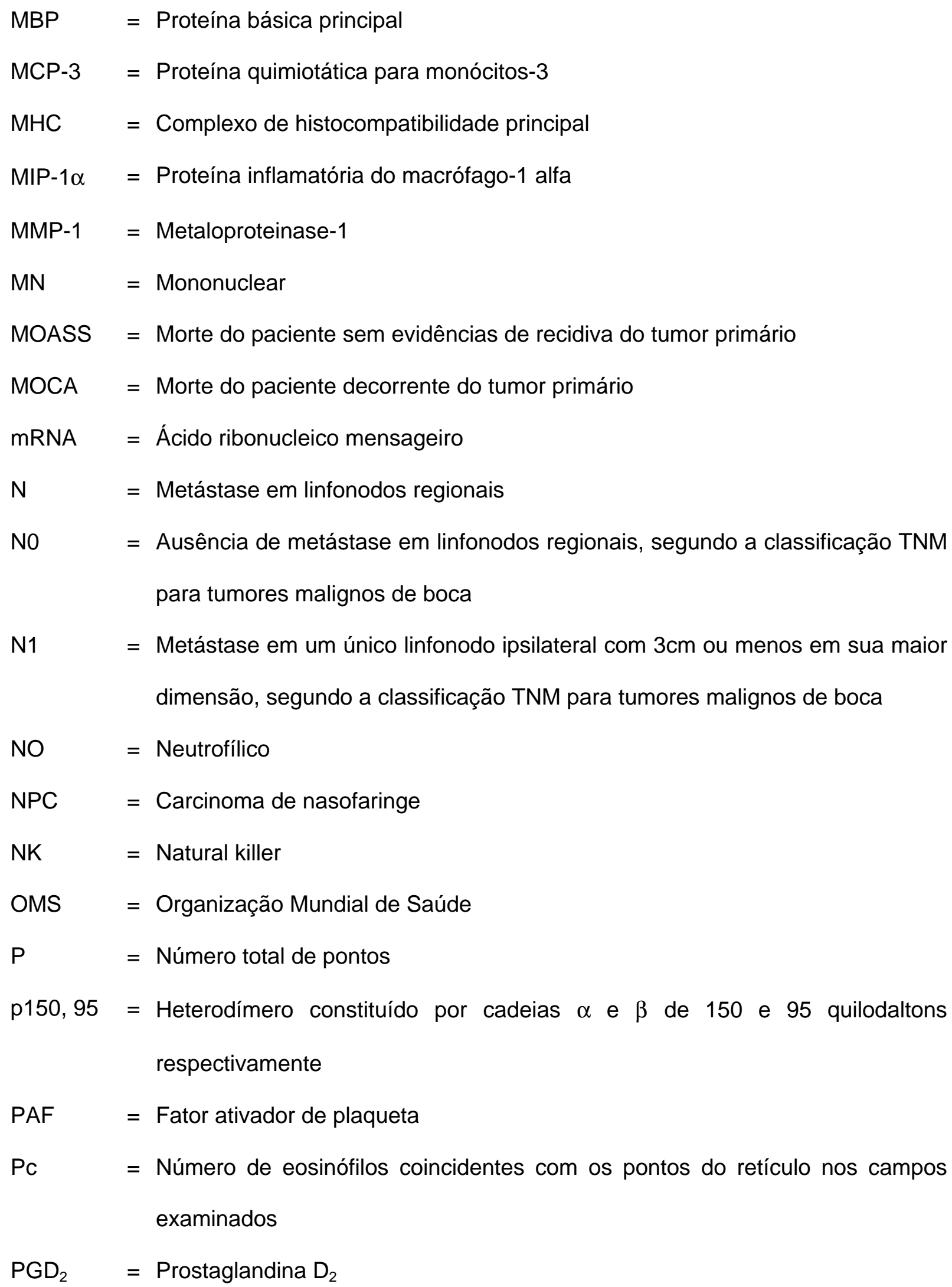




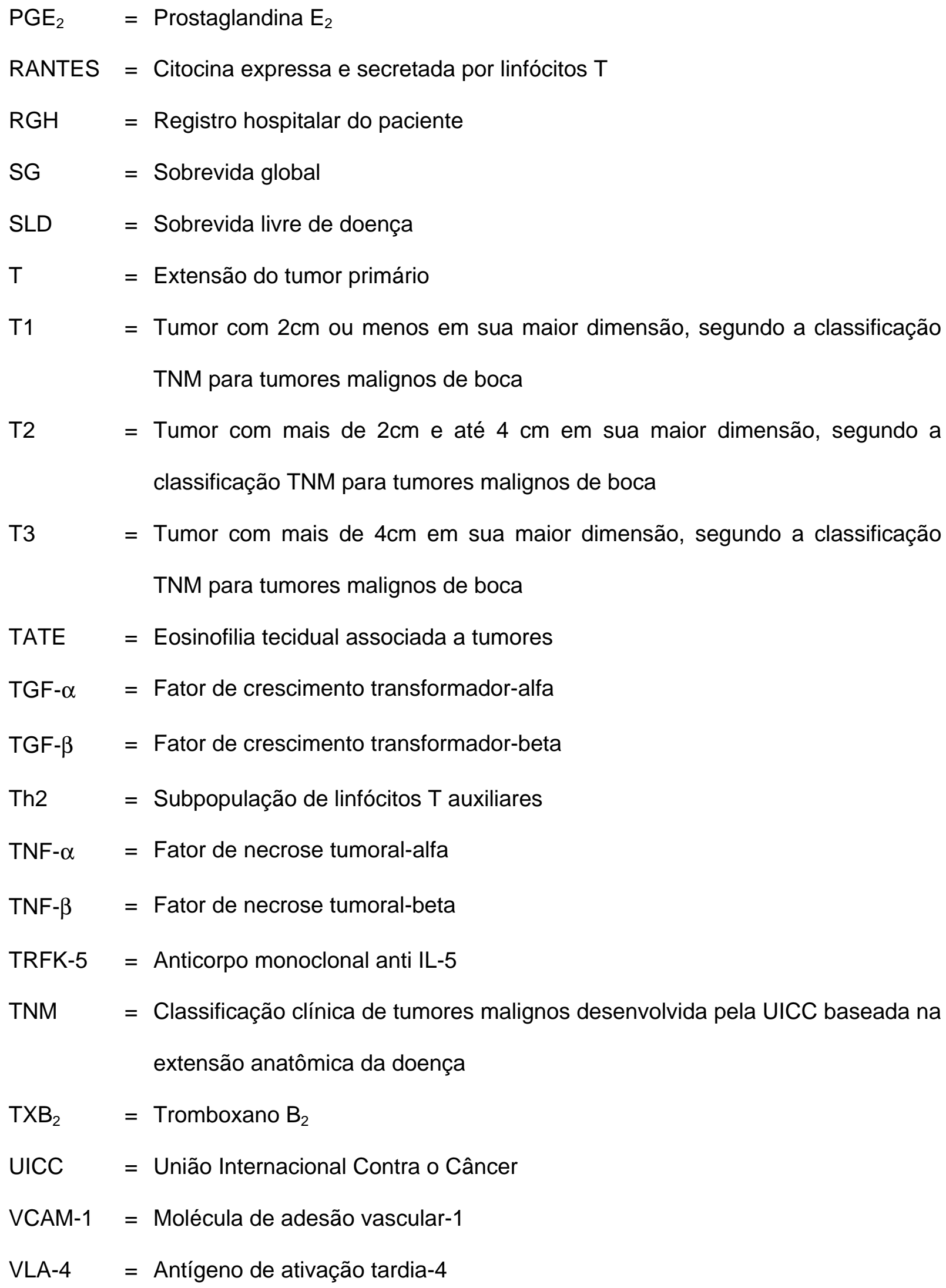




\section{RESUMO}

A eosinofilia tecidual associada a tumores (TATE) tem sido descrita, entre outras localizações, nas neoplasias malignas da região de cabeça e pescoço. O mecanismo de atração dos eosinófilos e seu papel nos tumores ainda não foram definidos, sendo correlacionados tanto com um prognóstico favorável, como desfavorável, ou mesmo não apresentando qualquer relação com a evolução dos pacientes. Com o objetivo de verificar a influência da TATE no prognóstico de carcinomas espinocelulares localizados na língua, assoalho bucal, área retromolar e gengiva inferior com estadiamento clínico II e III foram analisados 125 pacientes quanto às características clínicas, tratamento e evolução, bem como os aspectos microscópicos relativos à morfologia e invasão tumoral e presença do infiltrado inflamatório, destacando-se a eosinofilia tecidual, quantificada por meio de análise morfométrica. O número de eosinófilos obtidos nos carcinomas espinocelulares de boca variou de 0 a 392 por milímetro quadrado. A TATE foi classificada em discreta $(0$ a 26 $\mathrm{EOS} / \mathrm{mm}^{2}$ ), moderada (27 a $83 \mathrm{EOS} / \mathrm{mm}^{2}$ ) e intensa (84 $\mathrm{EOS} / \mathrm{mm}^{2}$ ou mais) e apresentou uma correlação estatisticamente significativa com a intensidade do infiltrado inflamatório mononuclear e com a localização do infiltrado inflamatório eosinofílico. A análise da eosinofilia tecidual como fator prognóstico feita pelo estimador produto-limite de KaplanMeier e pelo modelo de riscos proporcionais de Cox demonstrou que a eosinofilia tecidual intensa constitui um fator de prognóstico favorável independente nos carcinomas espinocelulares com estadiamento clínico II e III localizados na língua, assoalho bucal, área retromolar e gengiva inferior. Estes resultados sugerem uma função antitumoral dos eosinófilos cujos mecanismos devem ser melhor investigados. 


\section{INTRODUÇÃO}




\section{INTRODUÇÃO}

O câncer constitui uma importante causa de morbidade e mortalidade em todo o mundo. No Brasil, os dados epidemiológicos disponíveis atualmente e o aumento da incidência da doença permitem configurá-lo como sério problema de saúde pública ${ }^{33}$. Entre as localizações primárias da doença, destaca-se a boca, com uma estimativa de 10890 novos casos e 3077 óbitos para o ano 2000, segundo dados do Instituto Nacional de Câncer $(\text { INCA })^{17}$. O carcinoma espinocelular, também denominado carcinoma epidermóide, representa aproximadamente $90 \%$ a $95 \%$ das neoplasias malignas que ocorrem neste local $^{6}$, manifestando-se em seus diferentes sítios anatômicos, afetando principalmente a região posterior da língua e o assoalho bucal ${ }^{30}$.

O estabelecimento do prognóstico e o plano de tratamento dos carcinomas espinocelulares de boca baseiam-se principalmente no sistema $\mathrm{TNM}^{28}$. Segundo este sistema, tumores de pequenas dimensões e não disseminados apresentam um melhor prognóstico em relação àqueles com maiores proporções e metástase clinicamente detectáve $\mathrm{l}^{7,22,26,45}$. Entretanto, alguns tumores, embora apresentando o mesmo estadiamento clínico, demonstram padrões de crescimento e evolução diferentes, sugerindo a necessidade da análise de outros fatores complementares capazes de nortear com maior precisão o prognóstico desta doença ${ }^{24}$. 
Assim sendo, atualmente, a busca incessante de metodologias e técnicas laboratoriais variadas, capazes de auxiliar na determinação do diagnóstico, prognóstico e plano de tratamento e, consequentemente, aumentar a taxa de sobrevida dos pacientes com câncer, tem possibilitado um conhecimento mais amplo do comportamento biológico e das diversas características microscópicas encontradas nos tumores malignos ${ }^{7}$.

Dentre as características microscópicas estudadas, destaca-se o infiltrado inflamatório. Freqüentemente, observa-se nas neoplasias malignas sólidas, incluindo os carcinomas espinocelulares de boca, a presença de um infiltrado inflamatório mononuclear composto principalmente por linfócitos T, células natural killer (NK) e macrófagos, independentemente da presença de outros estímulos inflamatórios, como infecção ou necrose $^{1}$, o que tem sido, de um modo geral, considerado um sinal indicativo de uma resposta imunológica favorável por parte do hospedeiro contra o câncer ${ }^{12}$.

A presença de outras células inflamatórias, como os eosinófilos, por exemplo, também tem sido relatada em tumores malignos localizados na pele ${ }^{60}$, mama ${ }^{2,47}$, pulmão ${ }^{34}$, trato gastrintestinal ${ }^{18,29,41,44,47,48}$, genitourinário ${ }^{41,47,67,68}$, boca ${ }^{23,24,27,41,47}$, laringe $\mathrm{e}^{14,15,23,24,55,65} \mathrm{e}$ faringe ${ }^{14,23,24,39,40}$. No entanto, a função destas células nestes tumores ainda não foi completamente estabelecida. A eosinofilia tecidual associada a tumores, também conhecida como TATE, pode estar relacionada com um prognóstico favorável ${ }^{15,18,23,24,29,44,47,48,65}$, desfavorável ${ }^{27,67,68}$ ou mesmo não apresentar influência sobre a evolução clínica dos pacientes ${ }^{39,40,55}$. Um dos fatores que tem contribuído para essa controvérsia é o fato de que a determinação da eosinofilia tecidual nos tumores tem se baseado em critérios subjetivos e discrepantes, tornando difícil a comparação entre os resultados obtidos nos diferentes trabalhos científicos realizados sobre o assunto.

Todos estes fatores evidenciam a necessidade de uma uniformização do material e da metodologia utilizados, de uma conceituação precisa de eosinofilia tecidual e 
de amostras representativas a fim de permitir a determinação do real valor da TATE no prognóstico de carcinomas espinocelulares da região de cabeça e pescoço. A obediência a estes critérios possibilitará a realização de trabalhos consistentes que possam trazer, no futuro, contribuições para o plano de tratamento dos pacientes, bem como para o desenvolvimento de novos alvos na terapia contra o câncer. 
2 REVISÃO DA LITERATURA 


\section{REVISÃO DA LITERATURA}

Os eosinófilos foram inicialmente identificados por EHRLICH, em $1879^{16}$. A partir de então, a observação da associação destas células com a asma e outras doenças alérgicas, com infecções parasitárias ${ }^{4,69}$, assim como sua íntima relação com alguns tumores $^{14,15,18,23,24,29,34,39,40,41,42,44,47,48,55,65,67,68}$, incitaram a curiosidade dos pesquisadores sobre o seu papel nestas e em outras doenças, resultando em um aumento exponencial no número de publicações dedicadas ao seu estudo ${ }^{69}$.

No entanto, permanecem ainda inúmeras controvérsias a respeito do comportamento biológico dos eosinófilos, os quais podem induzir tanto a efeitos benéficos, como deletérios ao hospedeiro ${ }^{71}$, podendo desempenhar diferentes funções de acordo com o local e as circunstâncias em que são recrutados ${ }^{4}$.

\subsection{Morfologia dos eosinófilos}

Os eosinófilos são células derivadas da medula óssea, sem capacidade de divisão mitótica e com cerca de $8 \mu \mathrm{m}$ de diâmetro ${ }^{69,70}$. Apesar do seu núcleo ser normalmente bilobulado, três ou mais lóbulos podem ser observados ${ }^{70}$. Além da medula óssea, são também encontrados com freqüência nos tecidos que apresentam interface com o ambiente externo, como o trato respiratório, gastrintestinal e genitourinário ${ }^{71}$ e em 
pequenas quantidades no sangue periférico, variando de 0 a $4 \%$ do total de leucócitos ${ }^{4}$. São, portanto, células predominantemente teciduais, apresentando-se na proporção de um eosinófilo no sangue para cada cem eosinófilos presentes nos tecidos ${ }^{4,43}$.

Em um indivíduo normal, os eosinófilos são produzidos em um período de cinco dias, lançados na circulação sangüínea onde permanecem cerca de 3 a 26 horas, migrando em seguida para os tecidos, ficando neste local por vários dias, quando finalmente morrem por apoptose ${ }^{4}$ e são subseqüentemente fagocitados pelos macrófagos ${ }^{69}$.

Estas células caracterizam-se pela presença de grânulos específicos esféricos ou ovóides aderidos à membrana celular, apresentando-se em número de aproximadamente 20 por célula ${ }^{21,69,72}$. Estes grânulos possuem um centro cristalóide circundado por uma matriz menos elétron-densa, visualizados somente com o auxílio da microscopia eletrônica. O centro cristalóide constitui-se da proteína básica principal dos eosinófilos (MBP) ${ }^{43,69,71,72}$, enquanto a matriz contém as outras três proteínas básicas dos grânulos dos eosinófilos: a proteína catiônica eosinofílica (ECP), a peroxidase eosinofílica (EPO) e a neurotoxina derivada dos eosinófilos (EDN ou EPX) ${ }^{21,69,71}$. Estas proteínas coram-se intensamente pela eosina, de onde deriva o nome atribuído a esta célula ${ }^{69}$. Acredita-se que os eosinófilos liberem o conteúdo de seus grânulos por três mecanismos: 1) necrose; 2) secreção, pela qual os grânulos fundem-se com a membrana celular e liberam seu conteúdo para o meio extracelular e 3) degranulação em etapas, resultando em um esvaziamento gradual do conteúdo dos grânulos específicos. Neste último caso, um variado espectro de aspectos morfológicos pode ser observado, desde a perda parcial ou completa da matriz, perda do centro cristalóide, até o esvaziamento completo dos grânulos ${ }^{70}$.

Os eosinófilos também contêm corpos lipídicos, organelas não aderidas à membrana celular e as principais responsáveis pelo armazenamento e metabolismo do ácido araquidônico ${ }^{69,71}$, sendo a principal fonte de prostaglandinas e leucotrienos no 
eosinófilo normal, já que contêm tanto o substrato, como as enzimas (cicloxigenase e 5lipoxigenase) necessárias para a síntese destes mediadores químicos ${ }^{70}$.

Os grânulos primários constituem um terceiro tipo de organela intracelular presente nos eosinófilos, as quais contêm os cristais de Charcot-Leyden, que também podem ser encontrados difusamente no núcleo e citoplasma dos eosinófilos ativados. Os grânulos primários são identificados pela ausência do centro cristalóide observado nos grânulos específicos, ou seja, são uniformemente elétron-densos ${ }^{21,70}$ e apresentam tamanhos variados, sendo freqüentemente maiores em relação aos grânulos específicos, representando aproximadamente $5 \%$ do total de grânulos presentes ${ }^{70}$. Os eosinófilos teciduais também apresentam pequenos grânulos, os quais contêm arilsulfatase e outras enzimas como a fosfatase ácida, por exemplo ${ }^{43,71}$.

\subsection{Desenvolvimento dos eosinófilos}

O crescimento e diferenciação dos eosinófilos ocorre na medula óssea e é promovido pela interação entre três citocinas: fator estimulador de colônia de macrófagos e granulócitos (GM-CSF), interleucina-3 (IL-3) e interleucina-5 (IL-5). As duas primeiras também estimulam o desenvolvimento de outras linhagens hematopoiéticas, enquanto a IL-5 age mais especificamente na linhagem dos eosinófilos ${ }^{21,37,53,57,69,71}$, atuando somente em uma fase tardia da diferenciação celular ${ }^{57,69,70}$. Apesar da IL-5 ter sido detectada nos mastócitos e eosinófilos, os linfócitos T são provavelmente a principal fonte desta citocina ${ }^{69}$.

Quanto à morfologia, os eosinófilos mielocíticos são células grandes e caracterizam-se por apresentar o núcleo unilobulado e complexo de Golgi, retículo endoplasmático e mitocôndrias em maiores quantidades, quando comparados às células maduras $^{70}$. Os eosinófilos tornam-se reconhecíveis quando desenvolvem os grânulos 
específicos contendo o centro cristalóide. Os grânulos específicos inicialmente estão presentes juntamente com um grande número de grânulos densos homogêneos, os quais desenvolvem posteriormente os grânulos primários, reduzindo o seu número à medida que a célula atinge a maturação ${ }^{69}$.

\subsection{Mediadores químicos derivados dos eosinófilos}

Os eosinófilos, assim como os outros leucócitos, produzem uma grande variedade de mediadores químicos. Serão abordados aqueles exclusivos dos eosinófilos ou que desempenhem um papel relevante na patofisiologia destas células.

\section{Proteínas catiônicas}

\section{- $\quad$ Proteína básica principal}

A proteína básica principal (MBP) constitui a proteína mais abundante nos eosinófilos sangüíneos, compondo o centro cristalóide dos grânulos específicos. Embora não apresente ação enzimática, constitui uma potente toxina apta a danificar vários parasitas, tanto helmintos, como protozoários, tendo também a capacidade de matar bactérias, células de mamíferos ${ }^{21}$ e células tumorais ${ }^{71}$, além de estimular a liberação de histamina pelos mastócitos e basófilos e de ativar neutrófilos e plaquetas ${ }^{20,71}$.

O efeito tóxico da MBP se dá por meio de um mecanismo de lesão à integridade da camada bilipídica da membrana celular $20,36,57$. 
A MBP não é exclusiva dos eosinófilos, estando também presente nos basófilos, porém em quantidades muito menores ${ }^{21,43}$.

\section{- Proteína catiônica eosinofílica}

A proteína catiônica eosinofílica (ECP) está localizada na matriz dos grânulos específicos $^{57}$. Suas funções incluem uma marcante toxicidade a bactérias, helmintos, protozoários e células de mamíferos ${ }^{20,21,71}$. A ECP também pode degranular mastócitos ${ }^{20,43}$, neutralizar heparina e ativar o fator Hageman, calicreína e plasminogênio ${ }^{43}$.

Seu mecanismo de toxicidade envolve danos à membrana celular pela criação de poros ou canais nas células-alvo ${ }^{20,57}$, o que não ocorre com a MBP. As concentrações tóxicas da ECP são aproximadamente 20 vezes menores do que as da MBP, sendo esta uma possível explicação para sua maior toxicidade ${ }^{57}$. A ECP é exclusiva dos eosinófilos ${ }^{43}$.

\section{- Neurotoxina derivada dos eosinófilos}

A neurotoxina derivada dos eosinófilos (EDN/EPX) é uma outra proteína catiônica da matriz dos grânulos dos eosinófilos. Seu mecanismo de neurotoxicidade ainda não foi completamente esclarecido. Não existem evidências de que a EDN induza os mastócitos ou basófilos a liberarem histamina ${ }^{57}$.

Ao contrário das demais proteínas derivadas dos eosinófilos, a EDN é muito pouco tóxica para parasitas ou células de mamíferos ${ }^{21,69}$. 
A EDN recebe esta denominação por produzir neurotoxicidade (Fenômeno de Gordon) quando injetada no fluido cérebro-espinhal de animais experimentais, embora a ECP também apresente esse efeito ${ }^{69}$.

\section{- $\quad$ Peroxidase eosinofílica}

A peroxidase eosinofílica (EPO) funciona como uma toxina catiônica na ausência de peróxido de hidrogênio e como uma peroxidase na presença de peróxido de hidrogênio e íons halogênio. Agindo como uma proteína catiônica, a EPO tem a capacidade de matar parasitas e células de mamíferos ${ }^{21}$. Como uma peroxidase ela tem sua potência aumentada cerca de 10.000 vezes $^{69}$, resultando em uma maior capacidade de matar uma grande variedade de alvos, incluindo parasitas (helmintos e protozoários), bactérias, vírus e fungos, além de células tumorais e do próprio hospedeiro ${ }^{21,71}$.

\section{- $\quad$ Cristais de Charcot-Leyden (Lisofosfolipase)}

Os cristais de Charcot-Leyden (CLC) constituem 10\% das proteínas dos eosinófilos $^{69}$. Em condições de estimulação pela IL-5, é possível detectar a presença dos CLC não só nos grânulos primários, mas também na matriz nuclear e no citoplasma destas células ${ }^{57}$.

Os CLC também são encontrados em grandes quantidades nos basófilos ${ }^{57,69,70}$, no entanto sua função ainda não foi estabelecida ${ }^{69}$. 


\subsection{Outros mediadores químicos produzidos pelos eosinófilos}

\section{Citocinas}

Os eosinófilos são células capazes não somente de serem estimuladas pelas citocinas, mas são também aptas a produzi-las, possuindo, portanto, uma capacidade imunorregulatória ${ }^{57}$.

Produzem três citocinas que atuam como fatores de crescimento para os próprios eosinófilos, a GM-CSF, a IL-3 e a IL-5 $5^{21,50,72}$. Além disso, estas citocinas prolongam o tempo de vida dos eosinófilos, antagonizam a apoptose e aumentam a resposta efetora destas células ${ }^{72}$.

Outras citocinas produzidas pelos eosinófilos e que podem atuar na inflamação aguda e crônica incluem a IL-1 $\alpha$, IL-6 e a IL-8, além do fator de necrose tumoralalfa $(\text { TNF- } \alpha)^{57,69,70,72}$.

Estas células também podem gerar grandes quantidades do fator de crescimento transformador-alfa (TGF- $\alpha$ ) e do fator de crescimento transformador-beta (TGF- $\beta)^{70,72}$, sugerindo a possibilidade destas células apresentarem uma função importante no reparo, na remodelação tecidual e no desenvolvimento de fibrose pós-inflamatória ${ }^{43,70}$. Além disso, a detecção da síntese de TGF- $\alpha$ nos adenocarcinomas humanos e nos carcinomas bucais exclusivamente pelos eosinófilos por WONG et al. ${ }^{73}$, em 1990, também sugere que estas células contribuam para o crescimento dos tumores em função da capacidade do TGF- $\alpha$ estimular a proliferação tanto de células normais, como de células neoplásicas epiteliais, além de influenciar na angiogênese. 


\section{$\underline{\text { Metabólitos dos lipídios }}$}

Os eosinófilos têm capacidade de sintetizar os produtos do metabolismo do ácido araquidônico utilizando-se da via da cicloxigenase e principalmente da via da lipoxigenase ${ }^{43,71}$. $O$ tromboxano $B_{2}\left(T_{X B}\right)$ é o principal produto da via da cicloxigenase, embora pequenas quantidades de prostaglandina $E_{2}\left(P G E_{2}\right)$ e prostaglandina $D_{2}\left(P D_{2}\right)$ também sejam sintetizadas ${ }^{43}$. O metabolismo pela da via da 5-lipoxigenase forma predominantemente leucotrieno $\mathrm{C}_{4}\left(\mathrm{LTC}_{4}\right)^{57,72}$, que por sua vez é metabolizado em $\mathrm{LTD}_{4} \mathrm{e}$ este, subseqüentemente, em $\mathrm{LTE}_{4}$. Das células encontradas nos locais de inflamação, os eosinófilos apresentam a maior capacidade de síntese de $\mathrm{LTC}_{4}{ }^{57}$, um potente mediador que causa broncoconstrição e aumento na permeabilidade vascular ${ }^{21}$. Os eosinófilos também produzem pequenas quantidades de $\mathrm{LTB}_{4}$ (ao contrário dos neutrófilos que produzem grandes quantidades de $\mathrm{LTB}_{4}$ e quantidades mínimas de $\mathrm{LTC}_{4}$ ) e podem gerar quantidades substanciais de 15-HETE (15-ácido hidroxieicosatetraenóico) via 15-lipoxigenase ${ }^{69}$.

Além destes mediadores inflamatórios, os eosinófilos ativados liberam quantidades consideráveis do fator ativador de plaqueta $(\mathrm{PAF})^{4,43,57,72}$. O PAF tem inúmeras atividades farmacológicas, incluindo a ativação de plaquetas, neutrófilos e macrófagos e a indução de broncoconstrição ${ }^{21,57}$.

\section{Metabólitos do oxigênio}

Da mesma forma que os outros fagócitos, os eosinófilos também geram peróxido de hidrogênio e ânion superóxido em associação com a explosão respiratória ${ }^{57}$. 


\subsection{Fatores quimiotáticos para os eosinófilos}

Os mediadores envolvidos na atração dos eosinófilos incluem a fração $5 a$ do complemento (C5a), o PAF, o $\mathrm{LTB}_{4}{ }^{50,71}$, a histamina ${ }^{20}$, além de citocinas como a IL-2, IL-3, IL-5, GM-CSF, fator quimiotático para linfócitos (LCF) e RANTES ${ }^{50,71}$. Embora o LCF e a IL-2, ambos produzidos por linfócitos, tenham sido descritos como os agentes quimiotáticos mais potentes para eosinófilos ${ }^{50}$, o PAF e o C5a também são fatores quimiotáticos importantes ${ }^{21}$. A IL-3, IL-5 e GM-CSF constituem agentes quimiotáticos menos potentes e sua importância parece estar centrada principalmente na sensibilização dos eosinófilos à ação de outros fatores quimiotáticos, além de promover a eosinofilopoiese e aumentar a sobrevida destas células, como visto anteriormente ${ }^{50,70}$.

No entanto, a infiltração tecidual predominante de eosinófilos não pode ser explicada simplesmente pela liberação de fatores quimiotáticos como o C5a, PAF e LTB que estes também atuam ativamente no recrutamento de neutrófilos. Por outro lado, o recrutamento seletivo de eosinófilos poderia se dar pela ação de mediadores como a IL-5, por exemplo, a qual atua sobre eosinófilos, mas não sobre neutrófilos, embora possa também estimular a migração de basófilos. Outra citocina com esta característica é o LCF, produzido por linfócitos $\mathrm{CD}^{+}{ }^{50}$ e que desencadeia a migração de eosinófilos após sua ligação aos receptores CD4 dos eosinófilos (ausentes nos neutrófilos) ${ }^{43}$.

O fator quimiotático para eosinófilos da anafilaxia (ECF-A), liberado por células $T$, mastócitos e basófilos, constitui um outro fator que poderia causar a atração preferencial de eosinófilos ${ }^{43,51}$.

Um fator quimiotático importante é a eotaxina, uma citocina com ação exclusivamente sobre os eosinófilos, tanto no seu recrutamento, como na sua ativação. A eotaxina parece atuar em cooperação com a IL-5, ligando-se aos eosinófilos por meio de um 
único receptor, o CCR3. As prováveis fontes da eotaxina são células epiteliais, macrófagos, células $T$, mastócitos e neutrófilos ${ }^{10}$.

Outras citocinas com a função de atrair eosinófilos são a proteína inflamatória do macrófago-1 alfa $(\mathrm{MIP}-1 \alpha)^{10,21,70}$, a IL-8 e a proteína quimiotática para monócitos-3 $(\mathrm{MCP}-3)^{10,70}$.

\subsection{Ativação dos eosinófilos}

Acredita-se que os principais fatores que causam a ativação dos eosinófilos são as mesmas citocinas implicadas na formação de colônias de eosinófilos, sendo elas a IL-5, GM-CSF e a IL-3. Provavelmente estes fatores ativadores sejam produzidos por células mononucleares, incluindo as células T e monócitos ${ }^{21,71}$.

Outros potentes ativadores dos eosinófilos são o PAF e C5 $\mathrm{a}^{21}$.

\subsection{Receptores de superfície presentes nos eosinófilos}

Da mesma forma que os demais leucócitos, os eosinófilos expressam vários receptores de membrana através dos quais se comunicam com o ambiente extracelular ${ }^{69}$.

\section{Receptores envolvidos na adesão e migração dos eosinófilos}

O acúmulo de leucócitos nos locais de inflamação requer uma série de interações complexas, sendo sua migração dos vasos sangüíneos para o ambiente extracelular um aspecto crítico e que depende, entre outros fatores, da expressão de 
moléculas de adesão tanto nos próprios leucócitos, como nas células endoteliais ${ }^{50,69}$. Sabese que a adesão inicial dos leucócitos ao endotélio, intermediada pelas seletinas, se dá de forma tênue e reversível, sendo rapidamente suplantada por uma adesão mais firme e definitiva, intermediada pela adesão entre as integrinas expressas pelos leucócitos e as imunoglobulinas geralmente presentes no endotélio. É esta interação que possibilitará a transmigração das células inflamatórias para o ambiente extracelular ${ }^{9}$.

Estes mecanismos acima mencionados aplicam-se aos leucócitos de um modo geral, incluindo os eosinófilos. Assim, a adesão inicial dos eosinófilos pode ocorrer por meio da seletina-L, expressa na sua superfície ${ }^{70}$, no entanto, tanto a seletina- $E^{50,57,70,72}$, como a seletina- $\mathrm{P}^{70,72}$, presentes no endotélio, também podem mediar a adesão inicial dos eosinófilos. Embora estas células potencialmente utilizem as três seletinas, a seletina-P parece possibilitar uma ligação mais intensa com o endotélio, sendo portanto considerada como a mais importante na adesão inicial ${ }^{70}$.

Nas fases seguintes, a adesão e migração dos eosinófilos ocorre pela expressão de integrinas em sua superfície, sendo as principais a VLA-4, ${ }^{4,63,69}$, LFA-1 (CD11a/CD18), Mac-1 (CD11b/CD18) $)^{4,21,43,71}$ e p150,95 (CD11c/CD18) $)^{21,43,71}$.

A adesão da $\beta_{1}$ integrina VLA-4 ocorre principalmente com a molécula de adesão vascular-1 (VCAM-1). No entanto, o fato dos neutrófilos não expressarem VLA-4 ${ }^{4,50,53,63,69,72}$ seria uma possível via para o recrutamento seletivo de eosinófilos nos focos inflamatórios em determinadas situações ${ }^{43}$. Além disso, a expressão da VCAM-1 pode ser regulada pela IL-4, uma citocina associada a linfócitos Th2 e que, portanto, aumentaria a transmigração dos eosinófilos através do endotélio via VLA-4/VCAM-1 $1^{21,50,63,69}$.

Já a adesão das $\beta_{2}$ integrinas LFA-1 e Mac-1 ocorre principalmente com ICAM-1. Os eosinófilos, como os neutrófilos, monócitos e linfócitos podem se ligar à ICAM-1 
por meio desta via ${ }^{21,43,50,72}$.

Nos locais de inflamação, os eosinófilos geralmente estão presentes juntamente com outras células inflamatórias, incluindo neutrófilos, linfócitos e monócitos e, no entanto, o mecanismo exato pelo qual os eosinófilos, presentes em pequenas proporções no sangue circulante, são recrutados em grandes quantidades para os tecidos em determinadas situações ainda é incerto ${ }^{50}$.

\section{Outros receptores expressos pelos eosinófilos}

Os eosinófilos apresentam receptores para imunoglobulinas, incluindo imunoglobulina $\mathrm{G}(\lg G)^{4,71}$, responsável por mediar a citotoxicidade celular dependente de anticorpo (ADCC) destas células ${ }^{43}$, imunoglobulina E ( $\operatorname{lgE}$ ) (ausente nos neutrófilos), imunoglobulina A $(\lg A)^{4,71}$ e componentes do sistema complemento ${ }^{4}$.

Além destes, possuem também receptores para várias citocinas, incluindo a IL-2 $2^{50}$, IL-3, IL-5 e GM-CSF ${ }^{43,69,71}$ e provavelmente para interferon-alfa (IFN- $\alpha$ ), interferonbeta (IFN- $\beta$ ), interferon-gama (IFN- $\gamma$ ) e TNF- $\alpha$. Os eosinófilos também apresentam receptores para PAF e para $\mathrm{LTB}_{4}$, agentes quimiotáticos potentes para estas células. Existem evidências de que os eosinófilos apresentem receptores para histamina ${ }^{20}$, estrógeno, glicocorticóides e para agonistas beta-adrenérgicos ${ }^{21}$.

Os eosinófilos também expressam receptores CD4, normalmente associados a células $T$ auxiliares ${ }^{21}$ e podem ser induzidos a expressar proteínas do complexo de histocompatibilidade principal $(\mathrm{MHC})$ de classe $\|^{21,70,72}$ pela influência de citocinas como GM-CSF, IL-3, IL-4, e IFN- $\alpha$ e, portanto, poderiam interagir com linfócitos T CD4 ${ }^{+}$, funcionando como células apresentadoras de antígeno ${ }^{21,69,70,72}$. Além disso, as citocinas IL-3, 
IFN- $\gamma$, TNF- $\alpha$ e TNF- $\beta$ podem induzir os eosinófilos sangüíneos a expressar ICAM-1, o que facilitaria sua adesão a células $\mathrm{T}^{70,72}$.

\subsection{Eosinofilia}

Existem muitas condições associadas a uma elevação no número de eosinófilos, como, por exemplo, a asma, rinite alérgica, eosinofilia pulmonar, síndrome da imunodeficiência adquirida, doenças parasitárias, doenças cutâneas (dermatite atópica, urticária, edema), pênfigo, transplantes, terapia com a IL-2, hipersensibilidade a drogas, doenças cardiovasculares, neoplasias, doença de Hodgkin, histiocitose de células de Langerhans, doença de Kimura, síndrome hipereosinofílica, síndrome da eosinofilia/mialgia e a síndrome do óleo tóxico ${ }^{4,57,69}$. No entanto, deve-se destacar que na maioria das vezes a presença de um aumento tecidual localizado de eosinófilos não está acompanhada de um aumento no número de eosinófilos no sangue periférico ${ }^{4}$.

Têm sido observadas diferenças quantitativas e qualitativas entre os eosinófilos de pacientes com contagem normal e pacientes com hipereosinofilia ${ }^{57}$. Nos indivíduos com um número aumentado de eosinófilos, uma proporção destas células se apresenta menos densa em relação às encontradas nos indivíduos normais ${ }^{57,69}$, no entanto, o mecanismo desta heterogeneidade ainda não foi esclarecido. O eosinófilos hipodensos parecem ser vacuolados e conter grânulos de menor tamanho, embora em quantidades semelhantes aos eosinófilos normodensos ${ }^{69}$. Provavelmente estas células representem um fenótipo ativado de eosinófilos com uma maior capacidade citotóxica, aumento da produção de metabólitos do oxigênio, de produtos do ácido araquidônico, da liberação de substâncias de seus grânulos e da síntese e liberação de citocinas ${ }^{50,57}$. Os eosinófilos ativados apresentam uma atividade citotóxica potente para alvos cobertos por anticorpos (ADCC) ${ }^{21}$ e podem estar 
sensibilizados para responder a alguns agentes quimiotáticos que são minimamente ativos nos eosinófilos normais ${ }^{50}$.

É importante ressaltar que eosinófilos intactos não são sempre observados no local das lesões a eles relacionadas. No entanto, é possível demonstrar a presença de substâncias tóxicas provenientes dos grânulos dos eosinófilos mesmo na sua ausência quando da análise das biópsias, confirmando sua participação na patologia destas lesões ${ }^{57}$.

Alguns achados têm contribuído para se considerar a eosinofilia como parte de uma resposta imunológica dependente de linfócitos $\mathrm{T}^{57}$. A síntese de IL-4 e IL-5 por clones Th2 constitui o mecanismo mais provável ${ }^{50,53,71}$.

A IL-5 parece ser a principal citocina responsável por um aumento na produção dos eosinófilos ${ }^{53,71}$ e, juntamente com outras citocinas derivadas dos linfócitos $T$ ativados, influenciaria na expressão de moléculas de adesão presentes tanto no endotélio, como nos eosinófilos, resultando em um aumento da migração destas células em direção aos tecidos $^{53}$. Além disso, sua capacidade de sensibilizar os eosinófilos à ação de outros agentes quimiotáticos e seu efeito quimiotático, embora discreto, sobre estas células devem também ser considerados ${ }^{50,70}$.

Quanto ao papel da IL-4, esta parece regular a expressão da VCAM-1, aumentando a transmigração dos eosinófilos através do endotélio via VLA-4/VCAM-1 ${ }^{21,50,63,69}$.

Também observou-se que as citocinas derivadas de Th2 prolongam, pelo menos in vitro, o tempo de vida dos eosinófilos pela inibição da apoptose. Portanto, a possibilidade da inibição da apoptose estar relacionada com a eosinofilia é uma hipótese a ser considerada, mas que deve ainda ser melhor esclarecida ${ }^{58}$. 
Finalmente, há evidências de que a manutenção da eosinofilia dependa da produção contínua de hemopoetinas eosinofílicas ${ }^{57,58}$.

\subsection{Eosinofilia em câncer de cabeça e pescoço}

Segundo LEIGHTON et al. ${ }^{39}$, a eosinofilia tecidual associada a tumores (TATE) é caracterizada pela infiltração do estroma tumoral por eosinófilos não relacionada à presença de necrose e/ou ulceração. No entanto, este conceito não representa um consenso na literatura já que, em muitos trabalhos referentes ao assunto, os eosinófilos são quantificados baseando-se exclusivamente na sua presença ${ }^{14,15,19,23,24,27,47,55,65}$, sendo descritos não só no infiltrado inflamatório, mas também em íntima associação com as células tumorais ${ }^{40}$.

Neste contexto, identificou-se a ocorrência da TATE em tumores malignos de pele $^{60}$, mama ${ }^{2,47}$, trato genitourinário ${ }^{41,47,67,68}$, gastrintestinal $1^{18,29,41,44,47,48}$ e respiratório ${ }^{34}$, tendo sido também freqüentemente relatada na região de cabeça e pescoço, como laringe $\mathrm{e}^{14,15,23,24,55,65}$, faringe ${ }^{14,23,24,39,40}$, seio $\operatorname{maxilar}^{56}$ e boca ${ }^{23,24,27,41,47}$. No entanto, as observações feitas a partir destes estudos têm sido conflitantes, demonstrando uma correlação da eosinofilia tecidual tanto com um prognóstico favorável ${ }^{15,18,23,24,44,47,48,65}$, como desfavorável ${ }^{27,67,68,74}$, ou mesmo não estabelecendo qualquer tipo de correlação com a evolução dos pacientes analisados ${ }^{39,40,55}$.

O primeiro registro da ocorrência de eosinofilia tecidual associada a tumores foi feito por PRZEWOSKI ${ }^{49}$ e data de 1896. Embora vários estudos tenham sido realizados desde então, serão descritos a seguir somente aqueles restritos à região de cabeça e pescoço ou considerados de relevância para a compreensão do papel dos eosinófilos nos carcinomas espinocelulares de boca. 
Considerando-se o estudo da eosinofilia tecidual em tumores malignos exclusivamente da região de laringe, o primeiro trabalho a ser destacado foi realizado em 1986 por DESSY et al. $^{15}$ que analisaram 85 pacientes portadores de carcinoma espinocelular de laringe com o objetivo de verificar a intensidade do infiltrado inflamatório desses tumores, bem como a intensidade do infiltrado inflamatório eosinofílico e mastocitário isoladamente, além de verificar a existência de correlação entre estes componentes e o grau de diferenciação da neoplasia para fins prognósticos. Os pacientes foram submetidos à laringectomia total ou conservadora associada a esvaziamento cervical uni ou bilateral. Os cortes microscópicos foram obtidos a partir das peças cirúrgicas e corados pela Hematoxilina-Eosina, Giemsa e Azul de Toluidina. A determinação do grau de diferenciação dos tumores seguiu os critérios definidos pela Organização Mundial de Saúde (OMS) para carcinomas de laringe, sendo classificados em G1 (bem diferenciado), G2 (moderadamente diferenciado) e G3 (pouco diferenciado). Quanto à intensidade, o infiltrado inflamatório foi classificado em “+” (discreto), “++" (moderado) e “+++" (intenso). A graduação da intensidade do infiltrado inflamatório eosinofílico e mastocitário foi feita individualmente para cada tipo celular, por meio da observação de dez campos microscópicos aleatoriamente em um aumento de 400x, sendo classificados como "-" quando os eosinófilos ou mastócitos estavam ausentes ou sua presença era esporádica, como "+" quando se observava a presença de dez células por campo em pelo menos sete campos microscópicos e "++" quando havia mais de dez células por campo microscópico nos dez campos. Os resultados demonstraram que quanto maior o grau de diferenciação do tumor, mais intenso apresentava-se o infiltrado inflamatório associado. Além disso, observou-se que os eosinófilos estavam presentes no infiltrado inflamatório peritumoral de $93 \%$ das neoplasias G1, $73,5 \%$ das neoplasias G2 e $33,3 \%$ das neoplasias G3, destacando que em $28,8 \%$ dos carcinomas G1 e em $44,5 \%$ dos carcinomas G2 era observada uma eosinofilia tecidual intensa (++), o que não foi observado em nenhum caso G3. A partir destes resultados, os 
autores constataram que tumores pouco diferenciados não apresentavam infiltrado inflamatório eosinofílico significativo, enquanto tumores bem diferenciados apresentavam quantidades proporcionalmente muito maiores de eosinófilos no seu estroma. Da mesma forma, a intensidade do infiltrado inflamatório mastocitário também aumentava à medida que aumentava o grau de diferenciação tumoral. Na conclusão, partindo do conceito de que tumores bem diferenciados apresentam um prognóstico favorável, os autores destacaram o significado da presença dos eosinófilos na boa evolução dos carcinomas de laringe, já que estes foram encontrados principalmente em G1 e G2. Quanto aos mastócitos, os autores sugerem o desenvolvimento de mais estudos para a determinação do seu significado nestes tumores.

Também no estudo de THOMPSON; BRADLEY; GRIFFIN ${ }^{65}$, em 1994, 104 pacientes com carcinoma espinocelular invasivo de laringe foram avaliados por um período mínimo de cinco anos ou até o óbito. Os tumores variavam de T1 a T4 e N0 a N3. No exame inicial, $89 \%$ dos pacientes não apresentavam evidência clínica de metástase cervical. 0 tratamento primário realizado consistiu de radioterapia em 89 pacientes e cirurgia em 12 pacientes. Três pacientes foram considerados sem possibilidade de tratamento. As biópsias, coradas em HE, foram examinadas segundo a eosinofilia tecidual, o grau de diferenciação tumoral, presença de linfócitos, plasmócitos e neutrófilos. Quanto à classificação da eosinofilia tecidual, foi considerada discreta quando se observavam um a cinco eosinófilos por campo em grande aumento, moderada quando se observavam 5 a 20 eosinófilos e intensa quando se observavam mais de 20 eosinófilos. Os dados clínicos dos pacientes foram confrontados com as características microscópicas. Para os pacientes que tiveram uma sobrevida mínima de cinco anos após o diagnóstico do câncer ou que foram a óbito em um período menor do que cinco anos, porém sem sinais de recorrência, o prognóstico foi considerado bom. Para os pacientes que morreram em conseqüência do carcinoma de laringe em um período de cinco anos, o prognóstico foi considerado ruim. Os resultados 
demonstraram que 31 pacientes (30\%) apresentavam eosinofilia tecidual, sendo que somente três destes morreram em conseqüência do carcinoma de laringe em um período de cinco anos. Dos 73 pacientes (70\%) cujos tumores não apresentavam eosinofilia tecidual, 25 morreram de carcinoma de laringe em um período de até cinco anos. Estes achados foram estatisticamente significativos quando se aplicou o teste de associação pelo qui-quadrado. As demais características microscópicas examinadas não demonstraram correlação com o prognóstico. A análise da tabela de sobrevida de todo o grupo de pacientes em cinco anos demonstrou uma sobrevida significativamente melhor no grupo TATE positivo. A aplicação do modelo de riscos proporcionais de Cox demonstrou ser a eosinofilia tecidual e o local do tumor as únicas variáveis estatisticamente significativas na determinação do prognóstico nesta série de pacientes, sendo o local um fator de maior influência quando comparado à eosinofilia tecidual. Em função dos resultados apresentados, os autores concluíram que a TATE poderia ser considerada na seleção de pacientes para quimioterapia adjuvante.

Em 1995, SASSLER et al. $^{55}$ realizaram um estudo prospectivo no qual analisaram 248 pacientes portadores de carcinoma espinocelular de laringe com estadiamento III e IV a fim de determinar a prevalência e o significado prognóstico da eosinofilia tecidual nestes tumores. Os espécimes foram obtidos a partir de biópsias e corados em HE. Um único patologista foi o responsável pela análise da eosinofilia tecidual. Foram avaliados dez campos em cada caso e a quantidade de eosinófilos presentes foi classificada em discreta, moderada e intensa quando se observavam um a cinco, cinco a dez e mais de dez eosinófilos em média por campo em grande aumento, respectivamente. As demais características microscópicas consideradas relevantes na determinação do prognóstico, entre elas queratinização, pleomorfismo nuclear, padrão de crescimento, resposta inflamatória, resposta vascular e do estroma, além de necrose tumoral, foram analisadas por três patologistas sem conhecimento prévio das características clínicas, estadiamento clínico, grau de eosinofilia tecidual e evolução dos pacientes, cujo tempo 
médio de acompanhamento foi de 48 meses. A presença e o grau da eosinofilia tecidual foram correlacionados com as demais características microscópicas e clínicas (localização na laringe, estadiamento clínico, sexo, tratamento, resposta à quimioterapia, sobrevida global e sobrevida livre de doença). A análise microscópica demonstrou a presença de eosinofilia tecidual em $22,5 \%$ dos pacientes, sendo em $16,5 \%$ discreta, $4,4 \%$ moderada e $1,6 \%$ intensa. As únicas correlações encontradas com o aumento na eosinofilia tecidual foram uma resposta inflamatória intensa (infiltrado linfoplasmocitário) e um menor grau de pleomorfismo nuclear. Não foi observada correlação entre a presença ou ausência de TATE com a sobrevida livre de doença, com a sobrevida global dos pacientes ou com a resposta à quimioterapia. Portanto, os autores concluíram que a TATE não constitui um fator de prognóstico nos carcinomas espinocelulares de laringe avançados.

Quanto aos tumores malignos de nasofaringe, somente dois trabalhos se dedicaram a estudar a eosinofilia tecidual exclusivamente neste local. Inicialmente, $\mathrm{LOOI}^{40}$, em 1987, analisou a presença de eosinofilia tecidual associada a carcinomas de nasofaringe (NPC) em 422 tumores primários e suas 138 respectivas metástases regionais. Os espécimes, todos provenientes de biópsias, foram avaliados por meio de coloração de rotina. Descartando-se a eosinofilia tecidual associada a focos de necrose ou secreções, foi considerada presente quando se observavam mais de dez eosinófilos por campo em grande aumento e foi graduada como moderada quando da presença de mais de dez eosinófilos em dez campos e como intensa quando se observavam mais de 100 eosinófilos por campo. A eosinofilia tecidual foi observada em 110 tumores primários (26\%). Os eosinófilos estavam presentes principalmente no estroma entre os grupos de células neoplásicas, entremeados por linfócitos e plasmócitos. Em alguns casos, os eosinófilos infiltravam o tumor parecendo dividi-lo em ilhotas ou trabéculas ou mesmo circundando células tumorais solitárias. Eosinofilia moderada e intensa foram demonstradas em nove e quatro casos, respectivamente. Em cinco destes 13 casos, a contagem diferencial de leucócitos era 
conhecida e não demonstrava eosinofilia sangüínea. A eosinofilia tecidual foi observada mais freqüentemente em carcinomas não queratinizantes, quando em comparação com os carcinomas espinocelulares queratinizantes e com os carcinomas indiferenciados. Da mesma forma que nos tumores primários, a TATE prevalecia nas metástases de carcinomas não queratinizantes. Das 138 metástases, 38\% apresentavam eosinofilia tecidual, sendo que 8 espécimes demonstravam TATE moderada e cinco demonstravam TATE intensa. Observou-se também que a presença de TATE no tumor primário não estava necessariamente relacionada com eosinofilia nas metástases. Embora o autor tenha excluído a eosinofilia associada à necrose tumoral, já que esta poderia ser a causa deste evento, destaca o fato de nem todas áreas de necrose estarem relacionadas com eosinofilia tecidual. Sabendo-se que o eosinófilo é um modulador dos mastócitos nas reações de hipersensibilidade imediata, $\mathrm{LOOI}^{40}$ sugere que a TATE no NPC possa estar relacionada com a liberação do ECF-A resultante da degranulação dos mastócitos. É possível também que os linfócitos T que infiltram o tumor possam ser os responsáveis pela eosinofilotaxia para o tumor. Portanto, seria interessante investigar os subtipos de linfócitos $T$ no estroma do NPC e determinar existência de uma relação entre estas células e a presença de TATE. Um outra possibilidade seria a produção de um fator eosinofilotático pelas próprias células tumorais. Embora o autor tenha observado neste estudo que os carcinomas espinocelulares queratinizantes apresentavam o menor potencial para metástases em relação aos demais tipos microscópicos, não foi possível atribuir este fato à TATE. A maior prevalência de TATE foi observada nos carcinomas não queratinizantes e o autor supõe que o processo de desdiferenciação de células escamosas esteja relacionado com a produção ou liberação de agentes eosinofilotáticos.

Posteriormente, LEIGHTON et al. $^{39}$, em 1996, analisaram a prevalência e o significado da eosinofilia tecidual em carcinomas de nasofaringe. Foram incluídos na amostra 96 pacientes, cujas biópsias apresentavam-se disponíveis e com tamanho 
adequado para a avaliação do estroma tumoral. Os pacientes foram tratados com radioterapia e em caso de suspeita de metástase regional, realizou-se quimioterapia neoadjuvante. O período médio de acompanhamento dos pacientes foi de 57 meses. Os espécimes foram corados pela Hematoxilina-Eosina e analisados por microscopia óptica em grande aumento. A presença de eosinofilia tecidual foi considerada somente naqueles casos em que o infiltrado inflamatório eosinofílico não estava associado à ulceração ou necrose tumoral. Considerou-se eosinofilia discreta quando se observavam áreas com mais de dez eosinófilos por campo, foi considerada moderada quando havia mais de dez eosinófilos em dez campos e intensa se fossem observados mais de 100 eosinófilos por campo. Os resultados demonstraram a presença de eosinofilia tecidual em 31 espécimes (32,3\%), sendo discreta, moderada e intensa em $84 \%, 13 \%$ e $3 \%$ dos casos, respectivamente. Para fim de análise estatística, a TATE foi considerada presente somente nos casos em que era moderada ou intensa. Neste estudo, aplicando-se o estimador produto-limite de KaplanMeier, o teste log-rank e o modelo de riscos proporcionais de Cox, não foi possível demonstrar qualquer correlação entre eosinofilia tecidual e ocorrência de recorrência local, metástase a distância ou sobrevida dos pacientes. Com o intuito de facilitar a comparação com outros estudos, os autores classificaram um subgrupo pacientes de acordo com a evolução segundo a qual um segmento mínimo de dois anos sem evidência da doença era considerado favorável e, em caso de recorrência, persistência, metástase ou morte após o tratamento curativo, era considerado desfavorável. Aplicando-se o teste de associação pelo qui-quadrado e o teste de Fisher, mais uma vez não foi possível estabelecer qualquer relação entre eosinofilia tecidual e a evolução dos pacientes. Portanto, os autores concluíram que a TATE não constituiu um fator indicativo de prognóstico nos carcinomas de nasofaringe.

Em 1996, no estudo de DERON; GOOSSENS; HALAMA ${ }^{14}$, um total de 63 pacientes com diagnóstico de carcinoma espinocelular de cabeça e pescoço foram 
analisados quanto à presença de eosinofilia tecidual. Destes, 37 (58,7\%) localizavam-se na laringe, nove $(14,3 \%)$ na orofaringe e $17(27 \%)$ na hipofaringe. Os cortes microscópicos eram provenientes tanto de biópsias (30 casos), como de peças cirúrgicas (33 casos). Utilizando-se da coloração de Giemsa, a presença dos eosinófilos no infiltrado inflamatório foi avaliada por um único patologista sem conhecimento prévio da evolução dos pacientes. Após a análise de dez campos microscópicos em cada caso, o número médio de eosinófilos foi calculado. O tumor era considerado TATE positivo quando da presença de mais de dois eosinófilos por campo em média em grande aumento (750×). Para a determinação do estadiamento clínico foi adotada a classificação TNM de acordo com a União Internacional Contra o Câncer (UICC). A evolução foi classificada como favorável quando o paciente não apresentava evidências da doença em um período de dois anos após o tratamento inicial e desfavorável quando havia doença residual, recorrência e quando o paciente morria em conseqüência da doença. Dos 63 pacientes estudados, 11 (17,5\%) foram classificados como T1, 20 (31,7\%) como T2, 18 (28,6\%) como T3 e 14 e (22, 2\%) como T4, além disso, $40(63,5 \%)$ foram classificados como N0 e $23(36,5 \%)$ como N1-3. Em 38 (60,3\%) dos pacientes foram encontradas médias de menos de dois eosinófilos por campo e 25 (39,7\%) foram considerados TATE positivos. Quanto à evolução, em 36 pacientes $(57,1 \%)$ foi considerada favorável e em 27 (42,9\%) desfavorável. Os resultados demonstraram que 17 (68\%) dos casos TATE positivos apresentaram uma evolução favorável e 8 (32\%) uma evolução desfavorável. Portanto, a presença de TATE como um fator prognóstico em carcinomas de cabeça e pescoço, segundo os autores, foi confirmada do ponto de vista numérico neste estudo, não tendo sido, no entanto, suportada por uma correlação estatística através da aplicação do teste de associação pelo qui-quadrado. Os autores também consideraram que uma uniformidade no material examinado, no tipo de coloração utilizada e uma definição precisa de eosinofilia tecidual, associados a uma amostra maior e mais representativa de pacientes, constituem fatores necessários para a determinação do real 
valor da TATE no prognóstico dos carcinomas espinocelulares da região de cabeça e pescoço.

Um único caso de carcinoma de seio maxilar associado à eosinofilia sangüínea e infiltração tecidual maciça por eosinófilos foi relatado por SATO et al. ${ }^{56}$, em 1981 . O paciente era do sexo masculino e tinha 46 anos de idade. Foi realizada a biópsia pela qual estabeleceu-se o diagnóstico de carcinoma espinocelular pouco diferenciado com infiltração eosinofílica intensa. Ao exame hematológico também foi evidenciada eosinofilia sangüínea (16\% do total de leucócitos). Não foram detectadas metástases a distância, no entanto os linfonodos regionais do lado direito apresentavam-se palpáveis. O tratamento foi realizado por radioterapia, quimioterapia e ressecção cirúrgica da maxila, incluindo áreas adjacentes, como os linfonodos submandibulares e cervicais comprometidos. Aparentemente o paciente evoluiu sem evidências de lesão residual, recorrência ou metástase. Pôde-se destacar, neste caso, um decréscimo significativo na eosinofilia sangüínea após o término da terapia, porém seguido de um aumento súbito e transitório destas células, o qual foi rapidamente e espontaneamente revertido a índices compatíveis com a normalidade, variando de $2 \%$ a $0 \%$. Como a eosinofilia pode estar relacionada a doenças malignas e à radioterapia, a redução drástica dos eosinófilos pós-terapia poderia ser explicada pela redução na quantidade de complexos antígeno-anticorpo decorrentes da ressecção do tumor, os quais induziriam à eosinofilia, ou pela eliminação de um fator promotor de eosinofilia, supostamente produzido pelas células tumorais. Já o aumento súbito e transitório que se observou imediatamente após o decréscimo na eosinofilia sangüínea teria sido induzido pela radioterapia com $\mathrm{Co}^{60}$, embora este seja um evento raramente observado após irradiação da região de cabeça e pescoço. Finalmente, os autores concluíram que a eosinofilia sangüínea bifásica observada neste caso poderia estar associada a ambas as causas, neoplasia maligna e radioterapia. 
Por outro lado, até o presente momento, a única avaliação do significado da eosinofilia tecidual em carcinomas espinocelulares exclusivamente de boca foi realizada, em 1993, por HORIUCHI et al. ${ }^{27}$, enquanto pesquisavam fatores de prognóstico para carcinomas espinocelulares de boca bem diferenciados utilizando-se da análise clínica e microscópica de 31 casos. Os tumores localizavam-se na língua (13 casos), gengiva (sete casos), assoalho da boca (cinco casos), mucosa jugal (quatro casos) e palato (dois casos). As informações clínicas, incluindo o estadiamento (TNM) e o tamanho dos tumores, foram avaliados. Noventa e dois por cento dos casos apresentavam estadiamento clínico III ou IV. Cirurgia radical foi o tratamento aplicado em 22 pacientes e nove pacientes foram submetidos à realização de biópsia incisional ou excisional seguida de quimioterapia e radioterapia. A sobrevida média foi de 47 meses. Cortes microscópicos foram obtidos a partir das biópsias ou das peças cirúrgicas e corados pela Hematoxilina-Eosina e Azul de Toluidina. A análise microscópica incluiu a avaliação do índice mitótico, do grau de infiltração linfocitária e eosinofílica e a quantificação dos mastócitos. Também avaliou-se por meio da imuno-histoquímica a expressão do antígeno HLA-DR, tanto nas células tumorais, como nas células inflamatórias. A presença dos eosinófilos foi classificada em três categorias: ausente à discreta, moderada e intensa. Nenhum dos parâmetros microscópicos acima descritos demonstrou correlação com o estadiamento clínico, ocorrência de metástase ou recorrência do tumor. No entanto, a análise estatística realizada pelo estimador produto-limite de Kaplan-Meier, teste log-rank e modelo de riscos proporcionais de Cox demonstrou que o grau de infiltração eosinofílica e a expressão do antígeno HLA-DR nas células tumorais foram significativos na determinação do prognóstico. O grupo com infiltração eosinofílica intensa e os casos com reação positiva das células tumorais para o antígeno HLA-DR apresentaram um prognóstico menos favorável, no entanto, segundo os autores, o mecanismo destes achados ainda não foi elucidado. Além disso, não foi observada correlação entre eosinofilia tecidual e as outras variáveis avaliadas. Finalmente, 
os autores reafirmam a necessidade de estudos adicionais para o esclarecimento do papel dos eosinófilos na resposta imunológica do hospedeiro e na progressão tumoral.

Outros trabalhos discorreram sobre a ocorrência e a importância da eosinofilia tecidual em carcinomas espinocelulares de boca, porém em conjunto com tumores de laringe e faringe ${ }^{23,24}$, ou então incluindo em um mesmo estudo tumores de localizações distintas como no trabalho de LOWE; FLETCHER ${ }^{41}$, em 1984, em que a prevalência e o significado clínico da eosinofilia tecidual associada a carcinomas espinocelulares de boca, vulva, pênis, escroto e ânus foi investigada em um total de 275 casos. Os tumores que se apresentavam ulcerados ou com áreas de necrose foram descartados. A contagem dos eosinófilos foi feita em objetiva de grande aumento. Classificou-se a eosinofilia como moderada e intensa nos casos em que havia mais de dez e 100 eosinófilos por campo, respectivamente. Dos 136 casos de carcinoma espinocelular de boca analisados, 67 localizavam-se na língua, 42 na mucosa do lábio e mucosa jugal e 12 casos no palato. Destes, somente 15 apresentavam eosinofilia tecidual, sendo em sete deles moderada e em oito intensa. Na maioria dos casos com eosinofilia intensa, a presença dos eosinófilos foi observada tanto nas biópsias, como nas peças cirúrgicas, recorrências e linfonodos metastáticos, porém somente em um caso foi observada eosinofilia sangüínea. Os eosinófilos foram encontrados no estroma adjacente ao tumor, mas também envolvendo as células tumorais. Além dos carcinomas de boca citados, eosinofilia tecidual intensa foi observada somente em outros dois casos, um na vulva e um no ânus. Como não se observou eosinofilia tecidual associada a outros tumores primários ocorridos em dois dos pacientes com eosinofilia intensa, os autores sugeriram que a TATE esteja relacionada a um tipo celular tumoral em particular e não a uma predisposição de determinados pacientes frente a quaisquer tumores. A ocorrência de eosinofilia tecidual em tumores de variadas localizações e em linfonodos metastáticos descarta a possibilidade de se tratar de uma resposta específica de determinados locais, segundo os autores. Neste trabalho, não foi 
possível determinar a influência da eosinofilia no prognóstico dos tumores malignos estudados em função do número insuficiente de casos para se estabelecer este tipo de análise, sugerindo a necessidade do desenvolvimento de mais trabalhos com esse objetivo.

O objetivo de PASTRÒÁK; JANSA ${ }^{47}$, em 1984, foi estudar a presença dos eosinófilos no estroma de carcinomas espinocelulares de boca, adenocarcinomas gástricos, carcinomas mamários e carcinomas espinocelulares de cérvix uterino com o intuito de estabelecer uma correlação entre a presença destas células e os índices de sobrevida dos pacientes. A ocorrência dos eosinófilos foi dividida em três grupos: E1, quando o estroma tumoral apresentava apenas uma pequena quantidade de eosinófilos; E2, quando havia presença abundante de eosinófilos, porém distribuídos focalmente; e E3, quando os eosinófilos constituíam mais de $50 \%$ do infiltrado inflamatório. Dos 93 carcinomas espinocelulares de boca examinados, 24 apresentavam eosinófilos no estroma adjacente, dos quais cinco casos tiveram uma sobrevida de até um ano, dez tiveram uma sobrevida de um a cinco anos e os nove restantes tiveram uma sobrevida de mais de cinco anos. Todos os casos analisados enquadravam-se no grupo E1. De acordo com as observações dos autores, tanto no estroma dos carcinomas de boca, como gástricos e de mama, a infiltração eosinofílica era discreta e presente em poucos casos. Por outro lado, os autores consideraram os achados dos carcinomas de cérvix uterino significativos, já que os pacientes cujos tumores apresentavam uma eosinofilia marcante tiveram uma sobrevida de mais de cinco anos, enquanto os pacientes E1 apresentavam, parte deles, o mais baixo índice de sobrevida. Os autores consideraram a possibilidade da presença da TATE representar um resposta específica do hospedeiro contra as células tumorais. Isto se confirma pelo fato dos eosinófilos não estarem presentes abundantemente no cérvix uterino normal, bem como nas reações inflamatórias não específicas. A presença dos eosinófilos também seria explicada pela interação dos linfócitos e mastócitos com os antígenos 
tumorais, quando nesta resposta imune os linfócitos liberariam citocinas eosinofilotáticas. Uma outra possibilidade é a produção de substâncias eosinófilotáticas pelas próprias células tumorais. Apesar dos resultados deste trabalho sugerirem uma correlação favorável dos eosinófilos exclusivamente no câncer de cérvix uterino, os autores propõem que novas avaliações sejam feitas com números maiores de pacientes e em outras localizações.

GOLDSMITH; CRESSON, ASKIN²3, em 1987, analisaram 82 tumores da região de cabeça e pescoço quanto às características associadas a um prognóstico desfavorável. Destes 82 casos, 16 localizavam-se na boca, 51 na laringe e/ou hipofaringe e 15 constituíam metástases cervicais. As características microscópicas dos tumores foram correlacionadas com os dados obtidos a partir da citometria de fluxo, realizada em 46 casos, e com a evolução dos pacientes, considerada favorável quando não era evidenciada presença da doença em um período mínimo de dois anos e desfavorável nos casos com persistência, recorrência ou metástase após o tratamento. Os parâmetros microscópicos foram avaliados em HE e incluíram a classificação de Broder e a classificação de Bauer. Além disso, foram avaliados também o pleomorfismo celular, a atividade mitótica, o padrão de invasão tumoral, a presença de invasão perineural e embolização vascular, coilocitose, desmoplasia, infiltrado inflamatório e eosinofilia tecidual, sendo a intensidade do infiltrado eosinofílico classificada como 0 quando nenhum eosinófilo era observado por campo em grande aumento, 1+ quando se observavam cinco a dez eosinófilos por campo, 2+ quando se observavam 10 a 20,3+ quando se observavam 20 a 30 e 4+ quando se observavam mais de 30 eosinófilos por campo, sem no entanto especificar o número e a localização dos campos estudados. Aplicando-se o teste de Fisher, observou-se uma associação entre a evolução dos pacientes e a eosinofilia tecidual, a qual se mostrou um fator de prognóstico favorável. Dos 34 pacientes com TATE, 89\% evoluíram bem e 11\% evoluíram mal. Quando a eosinofilia tecidual estava ausente, $61 \%$ dos pacientes evoluíram bem e $39 \%$ evoluíram mal. Esta correlação pareceu ser mais acentuada com o aumento no grau da eosinofilia 
tecidual, embora o número de pacientes fosse muito pequeno nos grupos com alto grau para possibilitar uma significância estatística. Os aspectos microscópicos das metástases eram idênticos aos seus respectivos tumores primários em 13 dos 15 casos estudados. Desmoplasia e eosinofilia, quando presentes nos tumores primários, estavam também presentes na metástase cervical. Os autores concluíram que a eosinofilia tecidual constitui um parâmetro sugestivo de prognóstico favorável para tumores de cabeça e pescoço.

Também, GOLDSMITH et al. ${ }^{24}$, em 1992, analisaram microscopicamente 149 casos de carcinoma espinocelular de cabeça e pescoço, sendo 46 destes previamente estudados por GOLDSMITH; CRESSON, ASKIN $^{23}$, em 1987. A avaliação da evolução dos pacientes, bem como o estudo das variáveis microscópicas, seguiram os mesmos critérios utilizados em 1987. Foram analisados dez campos em cada um dos espécimes corados em HE e calculada a média do número de eosinófilos em cada caso. A eosinofilia tecidual foi graduada de 0 a 4+, sendo o 0 correspondente a uma média de zero a dois eosinófilos por campo em grande aumento, 1+ correspondente a valores que variavam de dois a dez eosinófilos por campo, 2+ correspondente a valores de 10 a 20 eosinófilos por campo, 3+ correspondente a uma variação de 20 a 30 eosinófilos por campo e 4+ correspondente a uma média de mais de 30 eosinófilos por campo. Na análise dos resultados, foram considerados somente 120 pacientes, já que 29 não apresentavam um seguimento clínico mínimo de dois anos. Das variáveis estudadas, somente a eosinofilia tecidual, o padrão de infiltração tumoral periférico e a invasão perineural apresentaram uma correlação significativa com a evolução clínica. Aplicando-se o teste de Fisher, a invasão perineural constituiu um fator indicativo de prognóstico ruim, enquanto a ocorrência de eosinofilia intensa (3+ e 4+) e de um padrão de invasão não infiltrativo ("pushing margins") foram associados com uma evolução favorável. De um total de 15 pacientes com eosinofilia tecidual intensa (12,5\% da amostra), 14 (93\%) apresentaram uma evolução favorável. Dos 105 pacientes com eosinofilia discreta (0 a 2+), 76 (72\%) apresentaram uma evolução 
desfavorável e 29 (28\%) evoluíram bem. Todos os 17 pacientes que desenvolveram metástase a distância apresentavam eosinofilia tecidual discreta ( 0 e 1+). Além disso, 0 estudo constatou que os pacientes com TATE intensa (2+ a 4+) que fracassaram no tratamento, desenvolveram somente metástase regional e não a distância, o que poderia representar, segundo os autores, um efeito protetor dos eosinófilos contra a disseminação tumoral. Foi encontrada também associação entre a eosinofilia tecidual intensa e o padrão de invasão tumoral não infiltrativo ("pushing margins"). A análise dos linfonodos comprometidos revelou a ocorrência de eosinofilia tecidual, inclusive com a mesma intensidade dos tumores primários. O fato dos linfonodos comprometidos apresentarem um infiltrado inflamatório eosinofílico sugere que a resposta eosinofílica não é específica do local e pode ser indicativa do transporte de fatores eosinofilotáticos para os linfonodos regionais. A partir destes resultados, concluiu-se que a eosinofilia tecidual constituiu a variável de maior importância na avaliação da evolução dos pacientes com câncer da região de cabeça e pescoço, seguida do padrão de infiltração tumoral, estadiamento clínico e invasão perineural. Observou-se também que, mesmo ajustando-se para $\mathrm{T}, \mathrm{N}$ e estadiamento clínico, existiu uma associação significativa entre a TATE e o prognóstico.

Trabalhos experimentais também têm sido desenvolvidos com 0 intuito de desvendar o papel dos eosinófilos nos carcinomas espinocelulares de boca. O primeiro trabalho a ser destacado foi realizado em 1975 por HEALY ${ }^{25}$. O objetivo do autor foi estudar a resposta inflamatória durante o desenvolvimento de carcinoma espinocelular DMBA (dimetilbenzantraceno) induzido na bolsa da bochecha de hamsters. Procurou-se estabelecer uma correlação entre as alterações epiteliais ocorridas nas diferentes fases de evolução da neoplasia com as alterações no número e tipo de células inflamatórias presentes no estroma adjacente, dentre elas os eosinófilos. Foram utilizados hamsters sírios, divididos em grupos de acordo com a idade e o sexo, além do grupo controle. Ambas as bolsas da bochecha dos animais foram pinceladas com DMBA três vezes por semana 
durante 13 semanas, ao final das quais múltiplos tumores haviam se desenvolvido. Em seguida, os animais foram sacrificados e obtidos cortes microscópicos corados em HE. As lesões ulceradas foram excluídas da amostra, reduzindo a possibilidade de ocorrência de inflamação decorrente de infecção local e as demais foram classificadas como hiperplasia focal, crescimento atípico (atipia epitelial associada à presença de uma membrana basal intacta) ou carcinoma. Foram contados os linfócitos, plasmócitos, eosinófilos e mastócitos localizados na submucosa adjacente às alterações epiteliais em aproximadamente nove campos em cada corte microscópico utilizando-se de uma objetiva 40×. A partir dos resultados pôde-se observar que os linfócitos e mastócitos se mantiveram em quantidades relativamente constantes a despeito das alterações epiteliais ocorridas. No entanto, com o estabelecimento do tumor, foi observada uma redução no número de plasmócitos acompanhada de um aumento no número de eosinófilos de $2 \%$ do total de células inflamatórias nas hiperplasias focais para $17 \%$ nos carcinomas, aumento este considerado estatisticamente significativo. No grupo controle não foram observadas alterações epiteliais ou mesmo infiltração eosinofílica. A possibilidade do aumento no número de eosinófilos se tratar de uma resposta inflamatória ao DMBA foi desconsiderada pelos autores, pois esta perduraria somente durante os primeiros dias de carcinogênese induzida.

Com o intuito de compreender a participação dos eosinófilos na transformação maligna do epitélio da mucosa bucal, GHIABI; GALLAGHER; WONG ${ }^{19}$, em 1992, estudaram a cinética da infiltração eosinofílica durante o processo de indução de carcinogênese química DMBA induzida, avaliando também a associação destas células com o epitélio neoplásico e a sua capacidade de produção de TGF- $\alpha$. Para isto, foi induzido o desenvolvimento de carcinoma espinocelular na bolsa da bochecha de hamsters sírios pela aplicação de solução de 0,5\% DMBA dissolvido em óleo mineral. A identificação e contagem dos eosinófilos foi feita utilizando-se uma combinação da coloração de Giemsa e DAB-Ni. 
$\mathrm{Na}$ avaliação do mRNA para TGF- $\alpha$, feita por meio da hibridização in situ, utilizou-se a coloração de Giemsa e a fluorescência com rodamina. Foi considerada eosinofilia a presença de dez ou mais eosinófilos por campo em um aumento de 200x. Os resultados demonstraram que os eosinófilos eram encontrados ocasionalmente na lâmina própria da mucosa bucal normal dos hamsters. Tanto no grupo tratado com DMBA como no grupo controle, observou-se um aumento progressivo no número de eosinófilos com o passar das semanas, aumento este mais acentuado no primeiro grupo. Constatou-se que o grupo de 12 a 16 semanas tratado com DMBA apresentou uma infiltração eosinofílica significativamente maior em relação ao grupo controle. Enquanto $78 \%$ dos carcinomas DMBA induzidos em hamsters apresentavam eosinófilos no seu estroma, somente 7\% dos animais com epitélio normal, hiperplásico ou displásico apresentavam infiltração eosinofílica. Aplicando-se o teste de Fisher, a associação entre eosinofilia tecidual e a presença de epitélio neoplásico foi estatisticamente significativa. A hibridização in situ demonstrou que os eosinófilos da mucosa bucal normal não expressavam mRNA para TGF- $\alpha$. Contrariamente, $77,1 \%$ dos eosinófilos associados às áreas não tumorais, porém adjacentes ao tumor (epitélio normal, hiperplasia e displasia) e 80,7\% dos eosinófilos associados ao epitélio tumoral continham níveis detectáveis de mRNA para TGF- $\alpha$. Portanto, o número de eosinófilos contendo mRNA para TGF- $\alpha$ é significativamente maior nas áreas tumorais quando comparado ao epitélio normal. Segundo os autores, a eosinofilia tecidual associada a tumores poderia representar uma resposta não específica a um dano tecidual, uma reação ao carcinógeno, uma resposta específica ao carcinoma ou mesmo uma combinação destes fatores. Simultaneamente, os resultados deste trabalho sugerem que os eosinófilos são recrutados para os locais de desenvolvimento tumoral, estando predominantemente relacionados com o epitélio neoplásico e que a maioria dos eosinófilos associados a tumores expressam mRNA para TGF- $\alpha$, uma citocina multifuncional com múltiplas atividades biológicas como mitogênese, angiogênese e reabsorção óssea e que, em colaboração com outras células, poderia 
influenciar o processo de desenvolvimento tumoral.

Um trabalho interessante foi realizado por WONG et al. ${ }^{74}$, em 1999, ao examinarem o efeito do bloqueio da infiltração eosinofílica no desenvolvimento de tumores de boca em hamsters. Partindo do conhecimento da importância da IL-5 para a maturação, desenvolvimento terminal e amplificação dos eosinófilos in vitro, os autores utilizaram um anticorpo monoclonal anti IL-5, o TRKF-5, com o objetivo de interferir na disponibilidade desta citocina, visando a eliminação completa dos eosinófilos do infiltrado inflamatório tumoral. Foram utilizados 20 hamsters sírios dourados divididos em quatro grupos. O grupo I era formado por cinco hamsters tratados três vezes por semana com uma solução de $0,5 \%$ de DMBA dissolvida em óleo mineral e aplicada na bolsa da bochecha esquerda. O grupo II era formado por cinco hamsters tratados somente com óleo mineral. O grupo III consistia de cinco hamsters que receberam $0,5 \%$ DMBA em óleo mineral e $5 \mathrm{mg}$ de anticorpo monoclonal anti IL-5 administrado a cada duas semanas por injeção intraperitoneal. O grupo IV, com cinco hamsters, recebeu 0,5\% DMBA dissolvido em óleo mineral, além de $5 \mathrm{mg}$ de anticorpo controle para beta-galactosidase bacteriana por injeção intraperitoneal a cada duas semanas. As observações clínicas foram feitas semanalmente, anotando-se os achados de leucoplasia, eritroplasia, eritema, hiperqueratose, tamanho, número e morfologia tumoral e peso do animal. Após 14 semanas, os animais foram sacrificados e os últimos registros clínicos foram feitos. A invasividade e o grau de diferenciação dos tumores foram descritos e o crescimento tumoral calculado. A análise microscópica foi realizada selecionando-se aleatoriamente dez campos contendo epitélio neoplásico, sendo estes examinados com um aumento de 200× na região da lâmina própria adjacente ao tumor (grupos I, III e IV). Foi utilizada a coloração de Giemsa e os eosinófilos foram quantificados em microscopia de fluorescência com rodamina. A análise estatística demonstrou que os animais que receberam o anticorpo monoclonal anti IL-5 tinham uma quantidade significativamente 
menor de eosinófilos em relação àqueles que não tinham recebido. A quantificação das demais células inflamatórias como neutrófilos, linfócitos, mastócitos e macrófagos nos tumores foi similar em todos os grupos experimentais, sugerindo um efeito seletivo do TRKF-5 na depleção dos eosinófilos. Em seguida, procurou-se analisar se a depleção dos eosinófilos havia alterado o crescimento tumoral pela comparação entre os quatro grupos de animais. Com isso, verificou-se que o grupo II não apresentou crescimento tumoral, o grupo III apresentou o menor volume tumoral, o grupo I apresentou um volume intermediário e, finalmente, o grupo IV apresentou o maior volume entre todos os grupos estudados. Também constatou-se que o grupo tratado com TRKF-5 apresentou clinicamente um atraso no início do desenvolvimento tumoral quando em comparação com os demais grupos. Portanto, neste trabalho os autores constataram que o anticorpo monoclonal TRKF-5 pode eliminar com sucesso a eosinofilia tecidual associada a tumores. Além disso, observaram também que a eliminação da eosinofilia tecidual resulta em um atraso na detecção clínica inicial de tumores DMBA-induzidos na mucosa bucal de hamsters, bem como em uma redução do seu crescimento, sugerindo um papel dos eosinófilos na promoção da carcinogênese, talvez pela produção de citocinas como o TGF- $\alpha$, por exemplo. Segundo os autores, os próximos passos devem ser centralizados em estratégias experimentais para bloquear a eosinofilia tecidual associada a tumores e na determinação de um modelo experimental de desenvolvimento de câncer apropriado para a definição exata da contribuição celular e molecular dos eosinófilos na carcinogênese epitelial.

Embora o estudo de STÅHLE-BÄCKDAHL; PARKS ${ }^{60}$, em 1993, não aborde diretamente a eosinofilia tecidual em tumores de cabeça e pescoço, constitui um trabalho de interesse para a compreensão da função dos eosinófilos nos tumores. A capacidade de invasão e disseminação de uma neoplasia representa um importante fator na determinação do seu prognóstico. A invasão tumoral depende, entre outros fatores, da degradação da 
membrana basal e da matriz extracelular por enzimas proteolíticas, destacando-se as metaloproteinases. Diante destas constatações, STÅHLE-BÄCKDAHL; PARKS ${ }^{60}$ pesquisaram secções de carcinoma espinocelular invasivo de pele a fim de identificar os locais onde uma metaloproteinase específica, a 92-kd gelatinase, era produzida. Utilizandose a hibridização in situ, foi demonstrada a presença de mRNA para a enzima exclusivamente nos eosinófilos, no entanto, pela imuno-histoquímica, demonstrou-se a presença da enzima tanto nos eosinófilos, como nos neutrófilos do infiltrado inflamatório tumoral, não sendo observada sua presença em cortes de pele normal. Estes resultados, referentes a carcinomas espinocelulares de pele, sugerem uma capacidade de síntese da 92-kd gelatinase por parte dos eosinófilos e uma capacidade secretora desta enzima por parte dos neutrófilos, eventos estes críticos para o mecanismo de remodelação tecidual e invasão tumoral. No entanto, segundo os autores ainda resta determinar os mecanismos pelos quais os eosinófilos controlam a produção destas enzimas.

No estudo de ONO et al. ${ }^{46}$, em 1997, a metaloproteinase-1 (MMP-1), considerada um fator de invasão tumoral, foi avaliada quanto à sua expressão em 14 carcinomas espinocelulares de cabeça e pescoço, um carcinoma verrucoso, um papiloma e em dois casos classificados como "inflamação" por meio da técnica de hibridização in situ. Com o decorrer do trabalho, observou-se uma relação entre a expressão da MMP-1 e a eosinofilia tecidual e por esse motivo a expressão da IL-5, uma citocina envolvida na diferenciação e proliferação dos eosinófilos, também foi avaliada. Os resultados demonstraram que seis dos 18 casos estudados apresentavam positividade para expressão da MMP-1. Entre os carcinomas espinocelulares, a expressão foi detectada em quatro dos sete casos considerados bem diferenciados, mas não foi observada nos carcinomas espinocelulares moderadamente ou pouco diferenciados. A expressão da MMP-1 também foi detectada no carcinoma verrucoso e no papiloma, não sendo observada nos dois casos de "inflamação". Em todos os casos positivos, a expressão foi identificada no estroma 
adjacente ao tumor, coincidindo com a localização das células inflamatórias, mais especificamente com os eosinófilos. Quanto à eosinofilia tecidual, observada pela coloração de Luna, cinco dos 18 casos apresentavam eosinofilia intensa (três carcinomas espinocelulares bem diferenciados, um carcinoma verrucoso e um caso de "inflamação") e três apresentavam eosinofilia moderada (um carcinoma espinocelular, um papiloma e um caso de "inflamação"), sendo sua localização em relação ao tumor invariavelmente restrita ao estroma adjacente. A expressão do mRNA para IL-5 foi observada em todos os casos positivos para mRNA para MMP-1 e também coincidia com a localização dos eosinófilos presentes no estroma adjacente ao tumor. Em suma, nos carcinomas espinocelulares, no carcinoma verrucoso e no papiloma analisados, sempre que a eosinofilia tecidual era moderada ou intensa, havia positividade para a expressão do mRNA para MMP-1 e IL-5. Embora a discussão do trabalho tenha sido centrada no papel das metaloproteinases, os autores sugerem, a partir destes resultados, a existência de um mecanismo autócrino em que os eosinófilos facilitariam sua própria atividade, além de um papel destas células no processo de remodelação em resposta à invasão tumoral.

Evidenciando o interesse que existe há longo tempo dos pesquisadores em relação à TATE, já em 1981, LOWE; JORIZZO; HUTT² ${ }^{42}$ publicaram uma revisão da literatura sobre eosinofilia associada a tumores. Segundo os autores, existem poucos aspectos em comum entre os variados tumores com eosinofilia tecidual marcante, exceto pelo fato da maioria deles se localizarem em superfícies do corpo. Isoladamente, a eosinofilia tecidual estaria usualmente ligada a um bom prognóstico e a sangüínea a um prognóstico desfavorável, estando esta última mais comumente relacionada com neoplasias em fase avançada de evolução, com metástases múltiplas e nem sempre apresentando eosinofilia tecidual simultânea. Também discutiu-se que a eosinofilia tecidual e sangüínea constituiriam provavelmente fenômenos independentes. A eosinofilia sangüínea poderia representar uma resposta específica ao tumor por uma pequena parte dos pacientes que reagiria a qualquer 
tumor da mesma forma. A eosinofilia tecidual, por outro lado, nos trabalhos revisados, não se apresentava associada a áreas de necrose ou ulceração e poderia ocorrer em resposta à secreção de substâncias eosinofilotáticas ou como conseqüência do aprisionamento dos eosinófilos pelas células tumorais ou do estroma, sendo a primeira hipótese a mais provável. Todas estas teorias, no entanto, segundo os autores, demonstram a necessidade de maiores estudos a respeito do assunto.

Uma outra revisão da literatura sobre o papel dos eosinófilos em diversos tipos de câncer foi realizada por SAMOSZUK ${ }^{52}$, em 1997, abordando tanto a eosinofilia tecidual, como a sangüínea e levantou dois questionamentos principais acerca deste assunto: por que os eosinófilos estão presentes e qual sua função nos tumores? Quanto à primeira pergunta, a revisão dos trabalhos publicados até então deixou clara a indefinição quanto à natureza das células responsáveis pela produção de fatores eosinofilotáticos nos tumores, apesar de existirem inúmeros fatores comprovadamente quimiotáticos para eosinófilos. Quanto à função dos eosinófilos nos tumores, SAMOSZUK ${ }^{52}$ desconsidera um possível efeito antitumoral destas células e justifica o seu ponto de vista usando o exemplo de tumores agressivos que, a despeito da presença maciça de eosinófilos, continuam a proliferar e a se disseminar. Para o autor, uma possibilidade mais provável é a de que os eosinófilos façam parte de uma resposta do tecido conjuntivo aos danos teciduais causados pelo tumor em crescimento, tendo observado com freqüência uma associação entre a presença dos eosinófilos, tecido de granulação e fibrose nos tumores em humanos. Embora o autor não considere a eosinofilia como um fator de prognóstico para tumores sólidos ou hematológicos, acredita que os eosinófilos possam desempenhar um importante papel na interação do hospedeiro com o tumor por meio da angiogênese e da remodelação do tecido conjuntivo em resposta ao crescimento tumoral. Além disso, sugere que os eosinófilos possam prover indícios interessantes sobre a biologia dos tumores, particularmente em relação à produção de citocinas pelas células neoplásicas. 
Considerando-se especificamente a eosinofilia sangüínea, esta ocorre em aproximadamente $0,5 \%$ dos casos de neoplasias malignas, destacando as neoplasias hematológicas, podendo desaparecer após a remoção do tumor e reaparecer em caso de recidiva ou disseminação ${ }^{61}$. Geralmente tem sido relacionada com neoplasias em estágio avançado de evolução e com metástases múltiplas e pouco freqüentemente apresentam eosinofilia tecidual simultânea ${ }^{42}$, levando a crer que eosinofilia sangüínea e tecidual constituam fenômenos independentes ${ }^{24,42,47}$. Porém, não está ainda definido se a eosinofilia sangüínea teria a capacidade de influenciar negativamente na evolução do tumor ou se simplesmente refletiria a progressão ou metástase de um tumor ${ }^{41}$.

Neste contexto, deve-se ressaltar que a contagem isolada do número de eosinófilos no sangue oferece uma figura limitada e às vezes errônea do envolvimento dos eosinófilos em uma doença em particular. A contagem sangüínea de eosinófilos representa o balanço entre o índice da migração dos eosinófilos a partir da medula óssea e sua entrada nos tecidos. Uma vez nos tecidos, os eosinófilos podem sobreviver por muitos dias sob a influência de citocinas geradas localmente ${ }^{69}$. Além disso, as células circulantes estão em trânsito entre os locais de produção e os tecidos onde serão consumidas, sendo os seus números no sangue periférico somente um indicador muito rude de um estado dinâmico. Portanto, a eosinofilia sangüínea somente deve ser considerada significativa se for sustentada e reproduzível ${ }^{43}$. 
3 PROPOSIÇÃO 
O presente estudo tem o propósito de:

1. caracterizar os carcinomas espinocelulares primários de boca com estadiamento clínico II e III localizados na língua, assoalho bucal, gengiva inferior e área retromolar quanto aos seus aspectos clínicos, tratamento e evolução;

2. caracterizar os tumores acima mencionados quanto aos aspectos microscópicos relativos à morfologia, invasão e presença do infiltrado inflamatório, destacandose especialmente a eosinofilia tecidual;

3. quantificar a eosinofilia tecidual presente no parênquima e estroma dos carcinomas espinocelulares primários em estudo e classificá-la de acordo com a intensidade;

4. verificar a existência de associação entre a eosinofilia tecidual e as demais características clínicas e microscópicas analisadas;

5. verificar a influência da eosinofilia tecidual no prognóstico dos carcinomas espinocelulares de boca. 
4 MATERIAL E MÉTODOS 


\section{MATERIAL E MÉTODOS}

\subsection{População de estudo}

Os 125 pacientes estudados foram obtidos a partir da amostra previamente utilizada por KOWALSKI et al. $^{35}$, em 1999, composta por pacientes submetidos ao tratamento de carcinoma espinocelular de boca no Departamento de Cirurgia de Cabeça e Pescoço e Otorrinolaringologia do Centro de Tratamento e Pesquisa Hospital do Câncer, em São Paulo, entre março de 1970 e dezembro de 1992. Foram analisados os casos selecionados segundo os critérios de inclusão listados abaixo:

1) pacientes com tumor primário com o diagnóstico de carcinoma espinocelular confirmado por biópsia e localizado na língua, assoalho bucal, gengiva inferior e área retromolar;

2) pacientes não submetidos a tratamento prévio;

3) pacientes submetidos à cirurgia como tratamento inicial, com ou sem radioterapia pós-operatória;

4) tumores com estadiamento clínico II e III;

5) seguimento clínico completo; 
6) fragmento de tumor suficiente para análise microscópica;

7) disponibilidade dos respectivos blocos de parafina.

Os critérios de exclusão utilizados foram:

1) contra-indicação para cirurgia (pacientes considerados inoperáveis);

2) presença de outros tumores primários simultâneos;

3) pacientes submetidos à quimioterapia;

4) pacientes que recusaram o tratamento;

5) tumores com extensas áreas de ulceração e/ou necrose.

\subsection{Registro dos dados clínicos e microscópicos}

As informações clínicas referentes aos pacientes e as informações microscópicas relativas à peça cirúrgica foram registradas em formulário próprio (Figura 1) e obtidas a partir do banco de dados pertencente ao Hospital do Câncer. Estes registros incluíram a identificação e os dados demográficos dos pacientes, informações relativas à história clínica, ao exame locorregional, cirurgia, radioterapia pós-operatória, microscopia da peça cirúrgica inicial e evolução do paciente. No caso dos pacientes vivos, a evolução clínica foi atualizada até o ano de 1999 por meio de consulta aos respectivos prontuários arquivados no SAME (Serviço de Arquivo Médico) do referido hospital. 


\subsection{Análise microscópica qualitativa}

Para a análise microscópica dos tumores primários, realizou-se um corte de $3 \mu \mathrm{m}$ de espessura de cada tumor a partir dos blocos disponíveis no arquivo do Departamento de Anatomia Patológica do Hospital do Câncer, sendo estes corados pela Hematoxilina-Eosina (HE). Todos os procedimentos histotécnicos foram realizados no Laboratório de Histologia do Instituto Ludwig de Pesquisa Sobre o Câncer e seguiram os procedimentos de rotina.

A análise microscópica foi realizada individualmente por dois examinadores utilizando-se de um microscópio óptico binocular da marca Olympus, modelo $\mathrm{CH}-2$, sendo os pontos de discordância entre estes reavaliados e estabelecidos por um consenso entre ambos. Utilizou-se uma lâmina representativa do tumor primário de cada paciente com carcinoma espinocelular de boca, selecionando-se, aleatoriamente, aproximadamente 50 campos microscópicos em cada uma delas, com um aumento de 400×, para a determinação das características microscópicas relativas à morfologia e infiltração tumoral, bem como do infiltrado inflamatório associado.

\subsection{Análise microscópica quantitativa}

A eosinofilia tecidual tumoral foi quantificada por análise morfométrica com o objetivo de se estabelecer uma metodologia criteriosa e passível de reprodução, permitindo a comparação dos resultados obtidos com futuros trabalhos científicos sobre o assunto, já que na literatura, até então, a determinação da eosinofilia tecidual em tumores de cabeça e pescoço baseia-se em critérios subjetivos e discrepantes ${ }^{14,15,23,24,27,39,40,41,47,55,65}$.

Determinou-se o número de eosinófilos pela utilização do mesmo microscópio óptico ao qual foi adaptada uma ocular Kpl (8×), contendo um retículo de integração ZEISS 
de 25 pontos. Utilizou-se uma objetiva de imersão $100 \times$, resultando em um aumento final de 800x. O diâmetro do retículo de integração, obtido por meio de uma lâmina milimetrada, correspondia a $0,15 \mathrm{~mm}$, sendo a sua área igual a $0,0176625 \mathrm{~mm}^{2}$. Foram analisados 75 campos microscópicos (área $=1,3246875 \mathrm{~mm}^{2}$ ) percorridos aleatoriamente desde a superfície até a porção tumoral mais profunda, registrando-se o número total de eosinófilos encontrados. Calculou-se o número de eosinófilos por milímetro quadrado dividindo-se a média dos eosinófilos presentes nos 75 campos examinados pela área do retículo.

Também calculou-se a fração de volume ocupada pelos eosinófilos nos espécimes analisados utilizando-se o mesmo retículo de integração. Neste retículo, cada intersecção entre um ponto e uma linha é definida como um ponto e, a partir daí, foi feita a contagem dos eosinófilos coincidentes com estes pontos predeterminados. A fração de volume (FV) foi calculada dividindo-se o número de eosinófilos coincidentes com os pontos do retículo pelo número total de pontos existentes e expressa em porcentagem, como pode ser observado pela fórmula abaixo ${ }^{32,62}$.

$F V=(P c \div P) \times 100$, onde:

$\mathrm{FV}=$ fração de volume

$\mathrm{Pc}=$ número de eosinófilos coincidentes com os pontos do retículo nos 75 campos examinados

$\mathrm{P}=$ número total de pontos (número de pontos do retículo $\times 75$ campos) 


\subsection{Variáveis de estudo}

As variáveis analisadas neste estudo incluíram a coleta dos dados demográficos relativos aos pacientes como o sexo (masculino ou feminino), a idade e a raça (branca, amarela, negra ou outras).

Quanto à história clínica dos pacientes, as características pesquisadas foram o tabagismo, etilismo e a presença de lesões bucais prévias ao diagnóstico de carcinoma espinocelular. O tabagismo e etilismo foram graduados em $0,+,++,+++\mathrm{e}++++$, sendo no tabagismo cada "+" correspondente ao consumo de aproximadamente dez cigarros industrializados ou dois cachimbos ou dois charutos ou quatro cigarros de palha por dia e no etilismo cada "+" correspondente aproximadamente ao consumo de um copo de bebida destilada ou uma garrafa de cerveja ou meia garrafa de vinho por dia. Também foi assinalada a presença de eosinofilia sangüínea quando valores iguais ou maiores que $6 \%$ de eosinófilos fossem detectados no hemograma pré-operatório.

A localização do tumor primário foi registrada como 1-ponta da língua; 2-corpo da língua; 3-ponta e corpo da língua; 4-sulco pelve lingual; 5-assoalho bucal; 6-gengiva inferior; 7-área retromolar. A extensão do tumor foi registrada como 0-ausente; 1-língua; 2assoalho; 3-gengiva; 4-área retromolar; 5-lábio; 6-mucosa jugal; 7-palato; 8-loja amigdaliana.

As lesões foram classificadas em duas categorias: ulcerovegetante e ulceroinfiltrativa.

Os estadiamentos clínicos T (T1, T2 e T3) e N (N0 e N1) foram anotados. 
Quanto ao tratamento, registrou-se a data da cirurgia, a realização ou não de esvaziamento cervical, o tipo de esvaziamento cervical (ipsilateral ou ipsilateral e contralateral simultaneamente) e a realização ou não de radioterapia pós-operatória.

O infiltrado inflamatório (mononuclear e polimorfonuclear), hipercromatismo e pleomorfismo celular, mitoses atípicas, presença de pérolas córneas e disqueratose foram classificados em categorias como discreto, moderado ou intenso, utilizando-se de parâmetros comparativos entre os diferentes tumores analisados. Quando os parâmetros avaliados apresentavam-se ausentes, estes eram incluídos na classificação como discretos. Além disso, a distribuição (focal e difusa) e a localização (parênquima, estroma e ambos) relativas ao infiltrado inflamatório como um todo e, especificamente referente ao infiltrado inflamatório eosinofílico, também foram avaliadas.

A embolização vascular foi classificada em ausente, linfática, sangüínea ou ambas (linfática e sangüínea), enquanto as infiltrações perineural, muscular e óssea foram classificadas em ausente ou presente.

Também avaliou-se o número de linfonodos ipsilaterais e contralaterias comprometidos registrando-se estas variáveis nas seguintes categorias: nenhum linfonodo comprometido; um a quatro linfonodos comprometidos; mais do que quatro linfonodos comprometidos e sem esvaziamento cervical.

$\mathrm{Na}$ análise quantitativa, os resultados da morfometria por área e fração de volume foram registrados e a classificação da eosinofilia em discreta, moderada ou intensa foi feita exclusivamente a partir da morfometria por área utilizando-se dos tercis do número de eosinófilos por milímetro quadrado obtidos na amostra. Da mesma forma que na análise qualitativa, a classificação "discreta" incluiu tanto os casos em que a presença dos eosinófilos era escassa, como aqueles em que os eosinófilos apresentavam-se ausentes. 
Quanto à evolução dos pacientes, registrou-se a data da primeira recidiva, os locais da recidiva (0-não teve; 1-local; 2-pescoço ipsilateral; 3-pescoço contralateral; 4pulmão; 5-osso; 6-fígado; 7-outra à distância e 8-recidiva em local ignorado), a data do diagnóstico do segundo tumor primário, o local do segundo tumor primário, a data da última informação de seguimento e a situação na última informação de seguimento (1-vivo sem evidência da doença; 2-vivo com câncer; 3-morte pós-operatória; 4-morte decorrente do câncer e 5-morte por outras causas não relacionadas ao câncer).

O tempo, em meses, decorrido entre a data da cirurgia e a ocorrência da primeira recidiva ou até a última informação de seguimento, correspondeu à sobrevida livre de doença (SLD). Da mesma forma, considerou-se como sobrevida global (SG) o tempo, em meses, decorrido entre a cirurgia e o óbito ou a última data de seguimento.

\subsection{Análise estatística}

A análise dos dados foi feita, primeiramente, por meio de medidas de tendência central, dispersão e proporções.

Calculou-se o coeficiente de correlação de Pearson entre os resultados da morfometria por área e os resultados da morfometria por fração de volume.

A relação entre a eosinofilia tecidual tumoral e as características clínicas e microscópicas foi analisada por meio do teste de associação pelo qui-quadrado.

A avaliação da concordância entre o método qualitativo e quantitativo (morfometria por área) de classificação da eosinofilia tecidual foi feita aplicando-se a estatística Kappa. 
A análise dos fatores prognósticos foi feita pelo estimador produto-limite de Kaplan-Meier que estima a probabilidade do indivíduo não ter o evento, neste estudo representado pela recidiva e pelo óbito. A comparação entre as curvas foi feita pelo teste log-rank.

Além disso, utilizou-se o modelo de riscos proporcionais de Cox a fim de avaliar a independência da eosinofilia tecidual em relação ao conjunto de variáveis estudadas na determinação do prognóstico.

Em todas as análises foi utilizado o nível de significância igual a 5\%. 
5 RESULTADOS 


\section{$5 \quad$ RESULTADOS}

Neste capítulo, inicialmente serão apresentadas as características clínicas e microscópicas da população estudada, assim como os resultados da morfometria por área e por fração de volume. Em seguida, serão abordados os resultados obtidos a partir da aplicação dos testes estatísticos, incluindo a análise de sobrevida dos pacientes.

\subsection{Caracterização clínica da população de estudo e microscópica dos tumores}

\subsubsection{Características clínicas}

A análise de 125 pacientes com carcinoma espinocelular de boca revelou uma predominância marcante do sexo masculino, sendo constituída por 105 homens (84\%) e 20 mulheres (16\%). A idade mínima dos pacientes era 30 anos e a máxima 95 anos, sendo a média igual a 58 anos (desvio padrão $=12$ anos). Cento e treze eram da raça branca $(90,4 \%)$, três da raça negra $(2,4 \%)$, um $(0,8 \%)$ da raça amarela e os oito restantes $(6,4 \%)$ pertenciam a outras raças (Tabela 1). 
TABELA 1 - Número e porcentagem de pacientes acometidos por carcinoma espinocelular de boca, segundo características demográficas. Hospital do Câncer, São Paulo, 1970 a 1992

\begin{tabular}{lcc}
\hline \hline Características & $\mathbf{1}$ de pacientes & $\%$ \\
\hline Sexo & 105 & 84,0 \\
Masculino & 20 & 16,0 \\
Feminino & & \\
Raça & 113 & 90,4 \\
Branca & 3 & 2,4 \\
Negra & 1 & 0,8 \\
Amarela & 8 & 6,4 \\
Outras & 125 & 100,0 \\
\hline TOTAL & & \\
\hline \hline
\end{tabular}

O tabagismo e o etilismo foram fatores de risco constantemente observados na amostra estudada, sendo relatados por $84 \%$ e $67,2 \%$ dos pacientes, respectivamente, sendo que $64 \%$ eram tabagistas e etilistas simultaneamente. A pesquisa de lesões bucais prévias ao diagnóstico do carcinoma espinocelular de boca foi uma característica raramente documentada nos prontuários ( $4,8 \%$ dos casos). Observou-se a ocorrência de eosinofilia sangüínea em 34,4\% dos pacientes (Tabela 2). 
TABELA 2 - Número e porcentagem de pacientes acometidos por carcinoma espinocelular de boca, segundo fatores de risco e características clínicas dos pacientes. Hospital do Câncer, São Paulo, 1970 a 1992

\begin{tabular}{|c|c|c|}
\hline Características & 1 de pacientes & $\%$ \\
\hline \multicolumn{3}{|l|}{ Tabagismo } \\
\hline 0 & 8 & 6,4 \\
\hline+ & 13 & 10,4 \\
\hline++ & 43 & 34,4 \\
\hline+++ & 22 & 17,6 \\
\hline++++ & 27 & 21,6 \\
\hline Desconhecido & 12 & 9,6 \\
\hline \multicolumn{3}{|l|}{ Etilismo } \\
\hline 0 & 28 & 22,4 \\
\hline+ & 23 & 18,4 \\
\hline++ & 21 & 16,8 \\
\hline+++ & 13 & 10,4 \\
\hline++++ & 27 & 21,6 \\
\hline Desconhecido & 13 & 10,4 \\
\hline \multicolumn{3}{|c|}{ Tabagismo + etilismo } \\
\hline$+\mathrm{a}++++$ & 80 & 64,0 \\
\hline \multicolumn{3}{|c|}{ Lesões bucais prévias } \\
\hline Sim & 5 & 4,0 \\
\hline Não & 1 & 0,8 \\
\hline Desconhecido & 119 & 95,2 \\
\hline \multicolumn{3}{|c|}{ Eosinofilia sangüínea } \\
\hline Sim & 43 & 34,4 \\
\hline Não & 65 & 52,0 \\
\hline Desconhecido & 17 & 13,6 \\
\hline TOTAL & 125 & 100,0 \\
\hline
\end{tabular}


$\mathrm{Na}$ amostra estudada, os locais acometidos pelo carcinoma espinocelular foram, em ordem decrescente de freqüência, o corpo da língua $(51,2 \%)$, assoalho bucal $(22,4 \%)$, área retromolar $(8,8 \%)$, gengiva inferior $(6,4 \%)$, ponta e corpo da língua simultaneamente (5,6\%), sulco pelve lingual (3,2\%) e ponta da língua (2,4\%) (Tabela 3). Em 34,4\% dos casos, o tumor apresentava-se restrito ao seu local de origem, enquanto que 40,8\% estendiam-se além do local inicial para uma única área anatômica adjacente, 19,2\% para duas áreas, 4\% para três áreas e 1,6\% para quatro áreas anatômicas adjacentes.

TABELA 3 - Número e porcentagem de pacientes acometidos por carcinoma espinocelular de boca, segundo localização. Hospital do Câncer, São Paulo, 1970 a 1992

\begin{tabular}{ccc}
\hline \hline Localização & $\mathbf{1}$ de pacientes & $\%$ \\
\hline Corpo da língua & 64 & 51,2 \\
Assoalho bucal & 28 & 22,4 \\
Área retromolar & 11 & 8,8 \\
Gengiva inferior & 8 & 6,4 \\
Ponta e corpo da língua & 7 & 5,6 \\
Sulco pelve-lingual & 4 & 3,2 \\
Ponta da língua & 3 & 2,4 \\
\hline TOTAL & 125 & 100,0 \\
\hline \hline
\end{tabular}

Clinicamente, $32 \%$ das lesões eram ulcerovegetantes, $67,2 \%$ eram ulceroinfiltrativas e em um único caso $(0,8 \%)$ esta característica não foi determinada. Quanto ao tamanho das lesões na ocasião do diagnóstico, 0,8\% eram T1, 65,6\% eram T2 e $33,6 \%$ eram T3, adotando-se os critérios de estadiamento clínico definidos pela UICC ${ }^{28}$. 
Quanto ao comprometimento dos linfonodos regionais, 52,8\% eram N0 e 47,2\% eram N1, seguindo-se a mesma classificação ${ }^{28}$ (Tabela 4).

TABELA 4 - Número e porcentagem de pacientes acometidos por carcinoma espinocelular de boca, segundo características e estadiamento clínico tumorais. Hospital do Câncer, São Paulo, 1970 a 1992

\begin{tabular}{lcc}
\hline \hline Característica & $\mathbf{1}$ de pacientes & $\%$ \\
\hline Tipo de lesão & & \\
Ulcerovegetante & 40 & 32,0 \\
Ulceroinfiltrativa & 84 & 67,2 \\
Desconhecido & 1 & 0,8 \\
Estadiamento T & & \\
T1 & 1 & 0,8 \\
T2 & 82 & 65,6 \\
T3 & 42 & 33,6 \\
Estadiamento N & & \\
N0 & 66 & 52,8 \\
N1 & 59 & 47,2 \\
\hline TOTAL & 125 & 100,0 \\
\hline \hline
\end{tabular}

De acordo com os critérios de inclusão dos pacientes no estudo, $100 \%$ foram submetidos a cirurgia como tratamento inicial, sendo que em $2,4 \%$ das cirurgias não foi realizado o esvaziamento cervical, em $80,8 \%$ foi realizado o esvaziamento cervical ipsilateral e em $16,8 \%$ realizou-se esvaziamento cervical ipsilateral e contralateral simultaneamente. Quarenta e quatro por cento dos pacientes receberam radioterapia pós-operatória como complementação do tratamento (Tabela 5). 
TABELA 5 - Número e porcentagem de pacientes acometidos por carcinoma espinocelular de boca, segundo tratamento. Hospital do Câncer, São Paulo, 1970 a 1992

\begin{tabular}{lcc}
\hline \hline Característica & $\mathbf{1}$ de pacientes & $\%$ \\
\hline Esvaziamento cervical & 3 & \\
Não realizado & 101 & 2,4 \\
Ipsilateral & 21 & 80,8 \\
Ipsilateral e contralateral & & 16,8 \\
Radioterapia & 55 & \\
Sim & 70 & 44,0 \\
Não & 125 & 56,0 \\
\hline TOTAL & & 100,0 \\
\hline \hline
\end{tabular}

A ocorrência de recidiva foi observada em 58 pacientes $(46,4 \%)$. Os locais mais freqüentemente acometidos foram, em ordem decrescente, o próprio local do tumor primário $(51,7 \%)$, pescoço contralateral $(20,7 \%)$, pescoço ipsilateral $(12,1 \%)$ e outros locais (5,2\%). Em seis pacientes (10,3\%) detectou-se a ocorrência simultânea de recidiva em mais de uma localização, sendo $5,2 \%$ destas no local e pescoço ipsilateral, $1,7 \%$ no local e pescoço contralateral e 3,4\% no local e pescoço ipsi e contralateral.

Constatou-se o desenvolvimento de um segundo tumor primário em 18,4\% dos pacientes, sendo a região de boca a faringe (25\%), esôfago (20\%) e laringe (15\%) os locais mais freqüentemente acometidos. 


\subsubsection{Características microscópicas}

\section{$\underline{\text { Análise qualitativa }}$}

Utilizando-se de parâmetros comparativos entre os tumores, realizou-se a análise qualitativa das características microscópicas relativas ao infiltrado inflamatório presente, bem como à morfologia e infiltração tumoral, as quais podem ser observadas nas Tabelas 6, 7 e 8, respectivamente.

A distribuição do infiltrado inflamatório foi predominantemente difusa $(94,4 \%)$, localizando-se tanto no estroma, quanto no parênquima tumoral. Na maioria dos casos, o infiltrado inflamatório neutrofílico era discreto $(69,6 \%)$ e o infiltrado inflamatório mononuclear intenso $(67,2 \%)$ (Tabela 6).

O infiltrado inflamatório eosinofílico apresentava distribuição difusa em 59,2\% dos tumores e foi classificado como discreto em $45,6 \%$, moderado em $36 \%$ e intenso em 18,4\%. Sua localização restringiu-se ao estroma em $54,4 \%$ dos casos e em $45,6 \%$ da amostra observou-se a presença simultânea de eosinófilos no parênquima e estroma tumorais (Figura 2A e 2B e Tabela 6). 

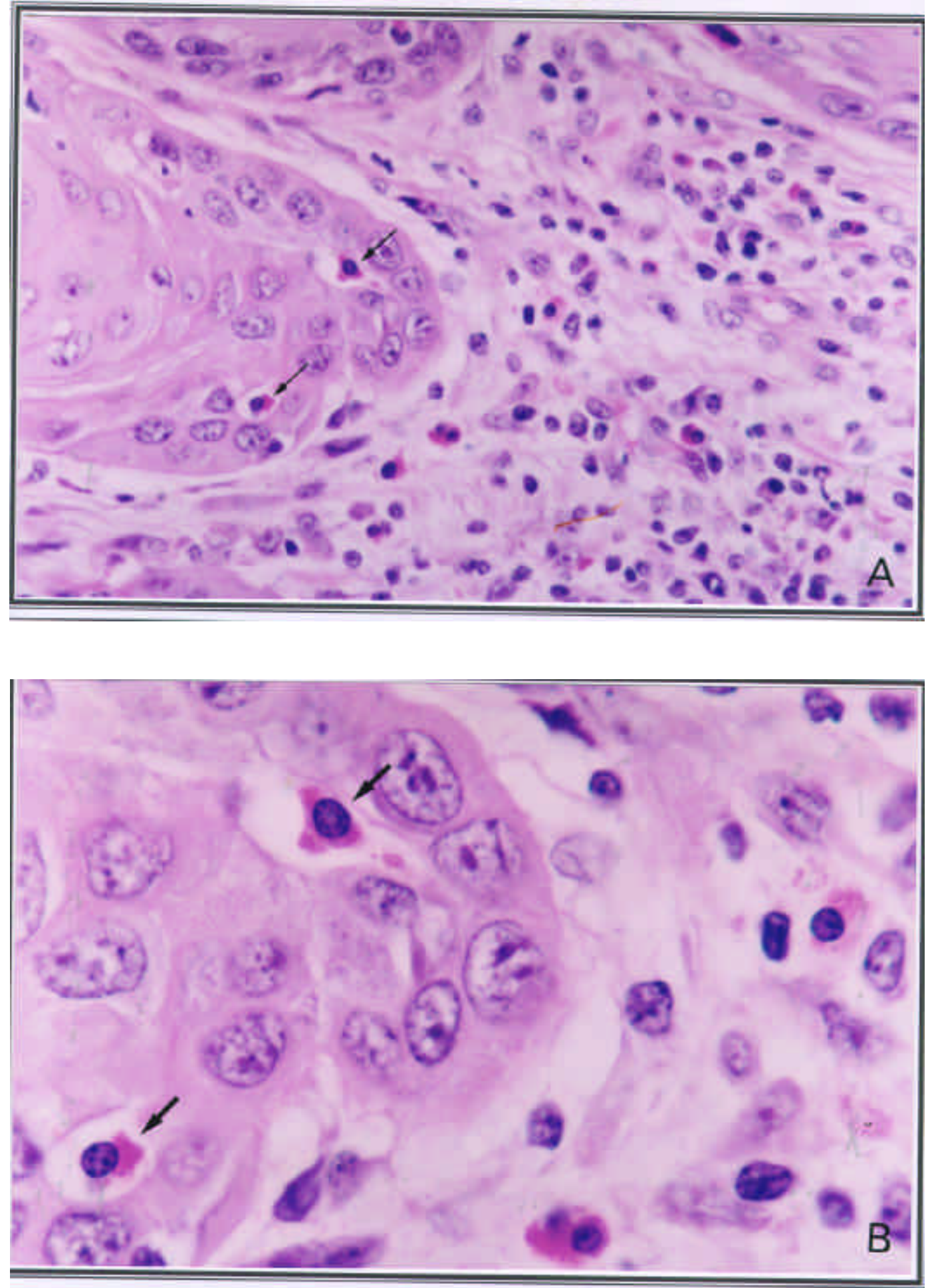

FIGURA 2 - Eosinofilia tecidual presente no estroma e parênquima tumoral. Observar a íntima associação dos eosinófilos com as células neoplásicas (setas). (HE; aumento original em $A=400 \times$ e em $B=1000 \times$ ) 
TABELA 6 - Número e porcentagem de pacientes acometidos por carcinoma espinocelular de boca, segundo distribuição, localização e intensidade do infiltrado inflamatório. Hospital do Câncer, São Paulo, 1970 a 1992

\begin{tabular}{|c|c|c|}
\hline Infiltrado inflamatório & 1 de pacientes & $\%$ \\
\hline \multicolumn{3}{|l|}{ Distribuição } \\
\hline Focal & 7 & 5,6 \\
\hline Difusa & 118 & 94,4 \\
\hline \multicolumn{3}{|l|}{ Localização } \\
\hline Parênquima & 0 & 0,0 \\
\hline Estroma & 8 & 6,4 \\
\hline Ambos & 117 & 93,6 \\
\hline \multicolumn{3}{|l|}{ Neutrofílico } \\
\hline Discreto & 87 & 69,6 \\
\hline Moderado & 21 & 16,8 \\
\hline Intenso & 17 & 13,6 \\
\hline \multicolumn{3}{|l|}{ Mononuclear } \\
\hline Discreto & 14 & 11,2 \\
\hline Moderado & 27 & 21,6 \\
\hline Intenso & 84 & 67,2 \\
\hline \multicolumn{3}{|l|}{ Eosinofílico } \\
\hline Discreto & 57 & 45,6 \\
\hline Moderado & 45 & 36,0 \\
\hline Intenso & 23 & 18,4 \\
\hline \multicolumn{3}{|c|}{ Eosinofílico - distribuição } \\
\hline Focal & 51 & 40,8 \\
\hline Difusa & 74 & 59,2 \\
\hline \multicolumn{3}{|c|}{ Eosinofílico - localização } \\
\hline Parênquima & 0 & 0,0 \\
\hline Estroma & 68 & 54,4 \\
\hline Ambos & 57 & 45,6 \\
\hline TOTAL & 125 & 100,0 \\
\hline
\end{tabular}


Hipercromatismo e pleomorfismo celular moderados foram identificados em $47,2 \%$ da amostra. A presença marcante de mitoses atípicas ocorreu somente em $16 \%$ dos tumores analisados e detectou-se a ocorrência discreta e intensa de pérolas córneas em igual porcentagem de casos $(41,6 \%)$, enquanto que a presença de disqueratose foi predominantemente discreta $(44,8 \%)$ (Tabela 7$)$.

TABELA 7 - Número e porcentagem de pacientes acometidos por carcinoma espinocelular de boca, segundo morfologia tumoral. Hospital do Câncer, São Paulo, 1970 a 1992

\begin{tabular}{|c|c|c|}
\hline Característica & 1 de pacientes & $\%$ \\
\hline \multicolumn{3}{|c|}{ Hipercromatismo } \\
\hline Discreto & 38 & 30,4 \\
\hline Moderado & 59 & 47,2 \\
\hline Intenso & 28 & 22,4 \\
\hline \multicolumn{3}{|l|}{ Pleomorfismo } \\
\hline Discreto & 29 & 23,2 \\
\hline Moderado & 59 & 47,2 \\
\hline Intenso & 37 & 29,6 \\
\hline \multicolumn{3}{|l|}{ Mitose atípica } \\
\hline Discreta & 62 & 49,6 \\
\hline Moderada & 43 & 34,4 \\
\hline Intensa & 20 & 16,0 \\
\hline \multicolumn{3}{|l|}{ Pérola córnea } \\
\hline Discreta & 52 & 41,6 \\
\hline Moderada & 21 & 16,8 \\
\hline Intensa & 52 & 41,6 \\
\hline \multicolumn{3}{|l|}{ Disqueratose } \\
\hline Discreta & 56 & 44,8 \\
\hline Moderada & 41 & 32,8 \\
\hline Intensa & 28 & 22,4 \\
\hline TOTAL & 125 & 100,0 \\
\hline
\end{tabular}


Embora $36,8 \%$ dos tumores não apresentassem embolização vascular, embolização linfática foi observada em $55,2 \%$, enquanto somente $2,4 \%$ tiveram embolização sangüínea e 5,6\% tiveram ambas. Infiltração tumoral perineural (Figura 3A) e muscular (Figura 3B) foram achados freqüentes (70,4\% e 84,8\%, respectivamente), ao contrário da infiltração óssea, observada somente em 7,2\% dos tumores (Tabela 8).

TABELA 8 - Número e porcentagem de pacientes acometidos por carcinoma espinocelular de boca, segundo infiltração tumoral. Hospital do Câncer, São Paulo, 1970 a 1992

\begin{tabular}{|c|c|c|}
\hline Característica & 1 I de pacientes & \% \\
\hline \multicolumn{3}{|c|}{ Embolização vascular } \\
\hline Ausente & 46 & 36,8 \\
\hline Linfática & 69 & 55,2 \\
\hline Sangüínea & 3 & 2,4 \\
\hline Ambas & 7 & 5,6 \\
\hline \multicolumn{3}{|c|}{ Infiltração perineural } \\
\hline Ausente & 37 & 29,6 \\
\hline Presente & 88 & 70,4 \\
\hline \multicolumn{3}{|c|}{ Infiltração muscular } \\
\hline Ausente & 19 & 15,2 \\
\hline Presente & 106 & 84,8 \\
\hline \multicolumn{3}{|c|}{ Infiltração óssea } \\
\hline Ausente & 116 & 92,8 \\
\hline Presente & 9 & 7,2 \\
\hline TOTAL & 125 & 100,0 \\
\hline
\end{tabular}



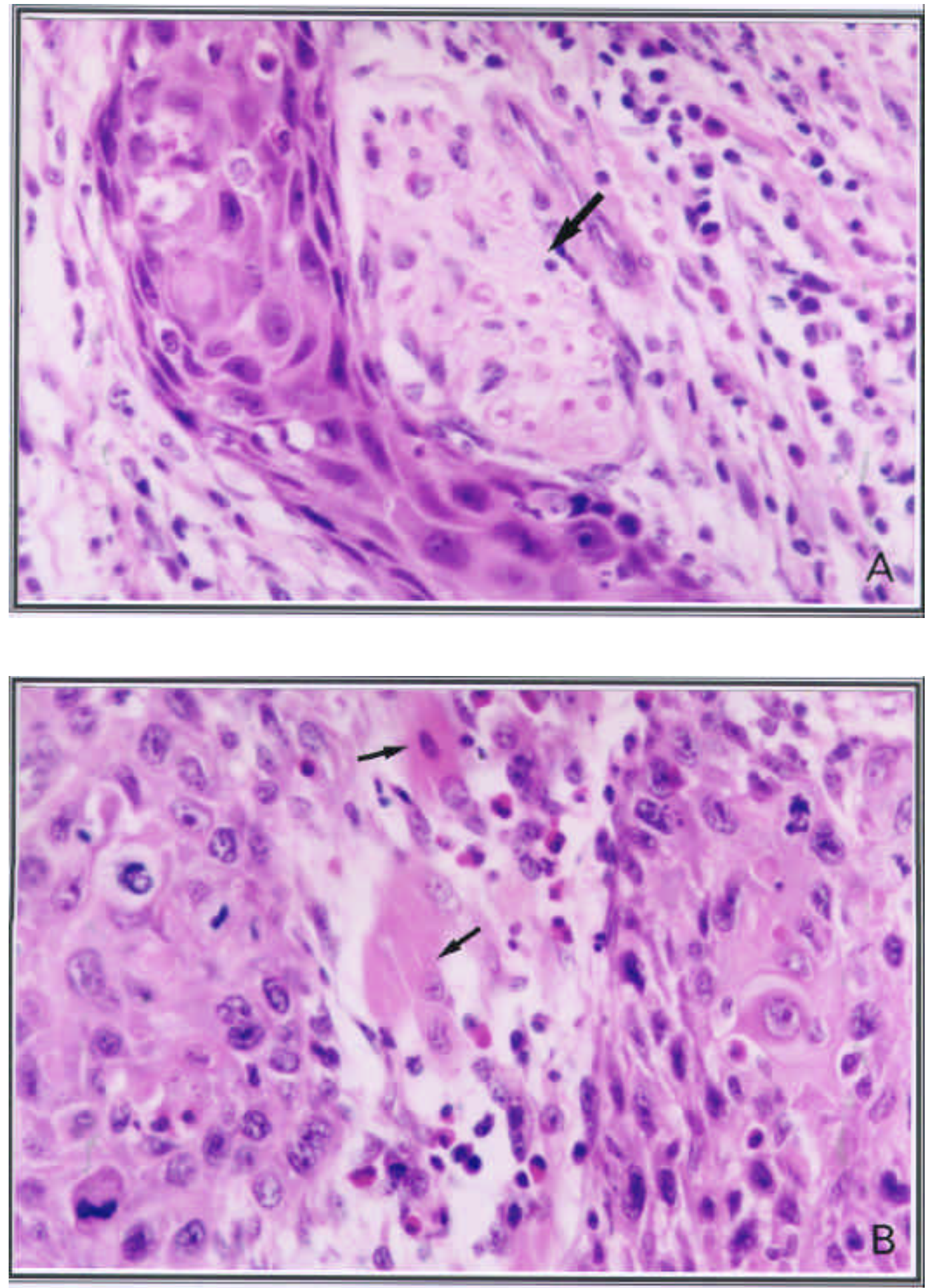

FIGURA 3 - Presença de infiltração tumoral perineural em A (seta) e infiltração muscular em B (setas) (HE; aumento original em A e B $=400 \times)$ 
O esvaziamento cervical ipsilateral foi realizado em 122 pacientes (97,6\%). Destes, a análise microscópica revelou ausência de metástase regional em 64 (52,5\%). Cinqüenta e três casos $(43,4 \%)$ apresentavam de um a quatro linfonodos positivos e cinco pacientes $(4,1 \%)$ apresentavam mais de quatro linfonodos positivos.

O esvaziamento cervical contralateral foi realizado em 21 pacientes (16,8\%). Destes, 15 casos $(71,4 \%)$ não apresentavam linfonodos positivos à análise microscópica, enquanto os seis casos restantes $(28,6 \%)$ apresentavam de um a quatro linfonodos positivos.

\section{Análise quantitativa}

\section{- Morfometria por área}

A realização da morfometria por área por meio da análise de 75 campos microscópicos em cada tumor estudado revelou uma média de 80,46 eosinófilos por milímetro quadrado (desvio padrão $=85,48$ eosinófilos por milímetro quadrado), sendo o valor mínimo de zero e o máximo de 392 eosinófilos por milímetro quadrado.

A classificação da eosinofilia tecidual de acordo com sua intensidade em discreta, moderada e intensa foi feita baseando-se nos tercis do número de eosinófilos por milímetro quadrado obtidos nos 125 casos estudados, resultando em três grupos distintos: 


\section{GRUPO I - Eosinofilia discreta (Figura 5A)}

0 a 26 eosinófilos por milímetro quadrado (42 pacientes)

\section{GRUPO II - Eosinofilia moderada (Figura 5B)}

27 a 83 eosinófilos por milímetro quadrado (41 pacientes)

\section{GRUPO III - Eosinofilia intensa (Figura 5C)}

$\geq 84$ eosinófilos por milímetro quadrado (42 pacientes)

A distribuição do número de eosinófilos por milímetro quadrado obtidos em cada caso e a sua classificação de acordo com a intensidade nos diferentes grupos acima descritos pode ser observada na Figura 4.

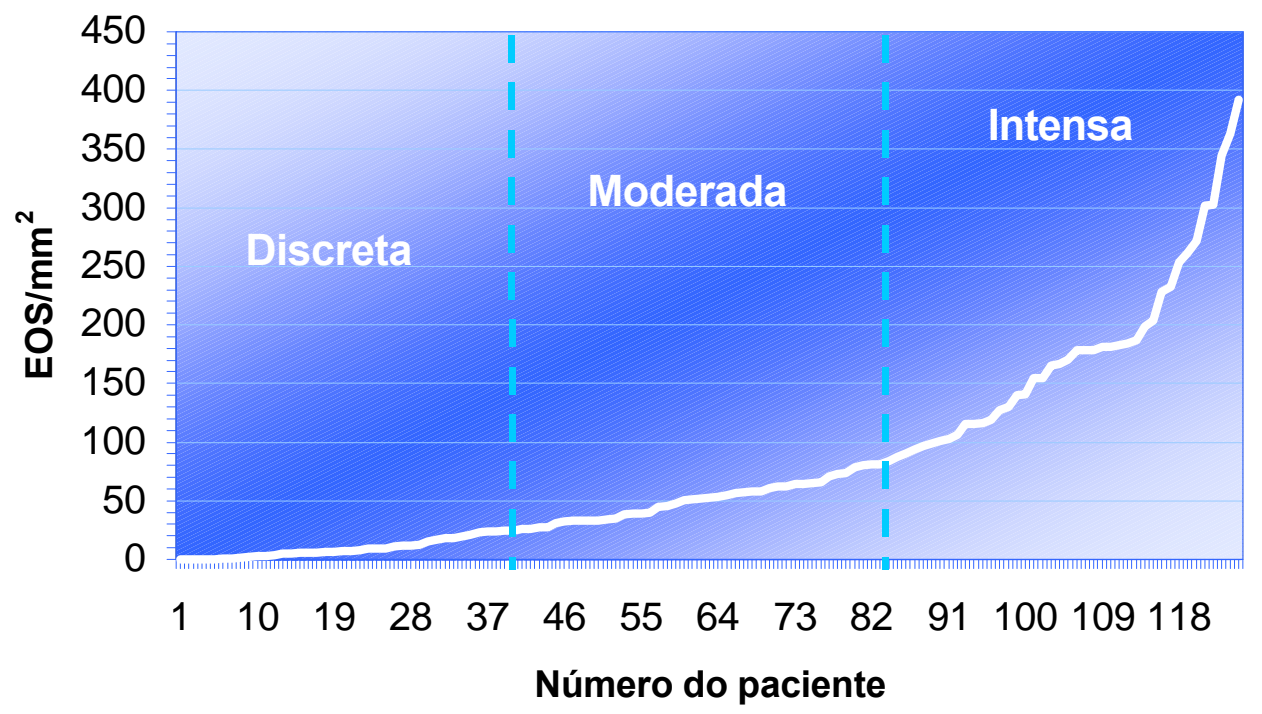

FIGURA 4 - Classificação da intensidade da eosinofilia tecidual segundo tercis do número de eosinófilos por milímetro quadrado obtidos nos 125 casos estudados 

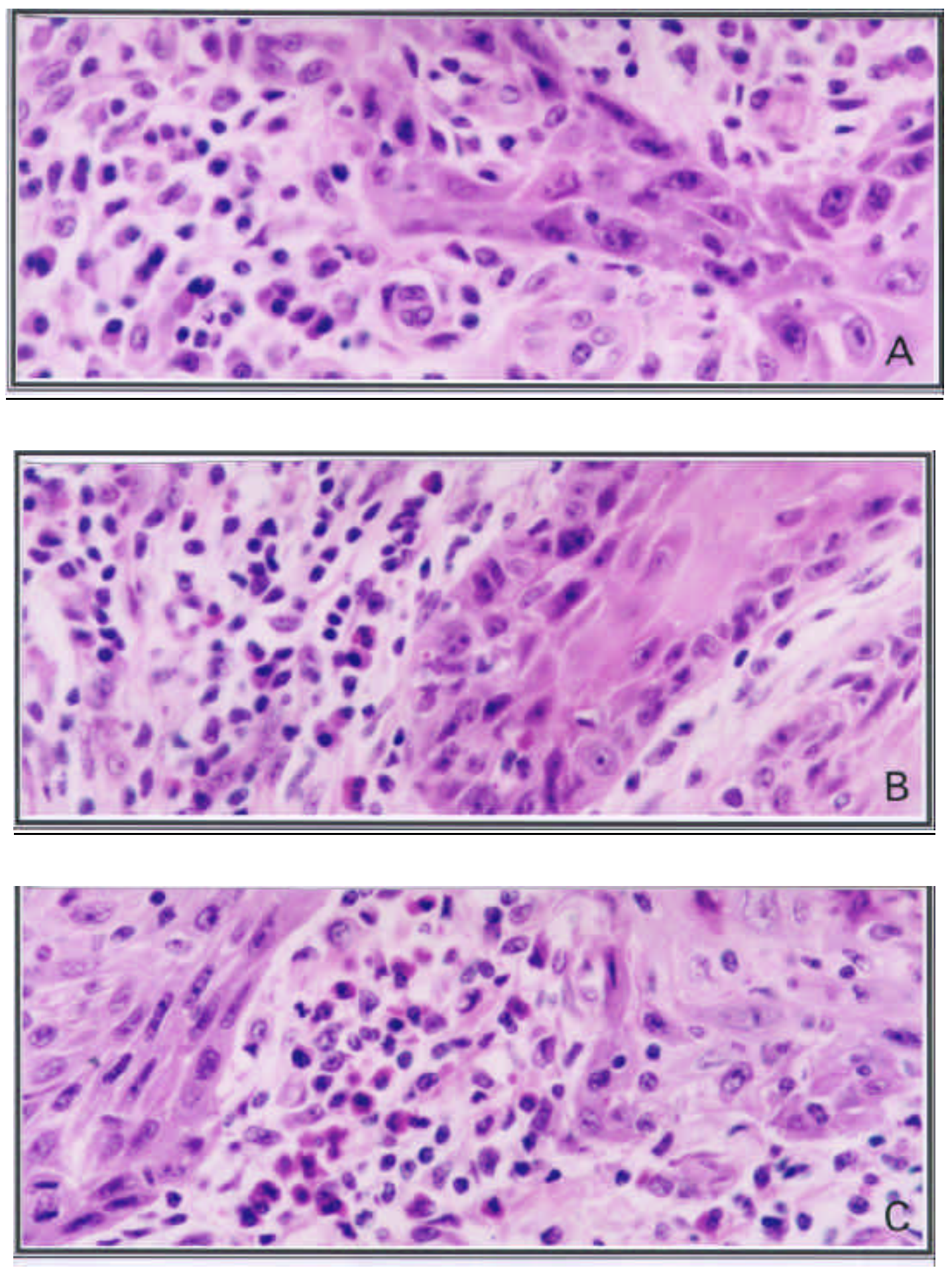

FIGURA 5 - Diferentes intensidades de infiltração dos carcinomas espinocelulares de boca por eosinófilos. Observar em A eosinofilia ausente/discreta, em B eosinofilia moderada e em C eosinofilia intensa (HE; aumento original em $A$, $B$ e $C=400 x)$ 


\section{- Morfometria por fração de volume}

A realização da morfometria por fração de volume pela análise de 75 campos em cada tumor estudado revelou que os eosinófilos ocupavam $0,50 \%$ dos tumores em média (desvio padrão $=0,58 \%$ ), sendo a porcentagem mínima ocupada igual a 0 e a máxima igual a $4,05 \%$.

\section{- Comparação entre morfometria por área e morfometria por fração de volume}

Realizou-se a comparação entre a morfometria por área e a morfometria por fração de volume utilizando-se o coeficiente de correlação de Pearson, o que resultou em uma correlação de 0,87 (Figura 6).

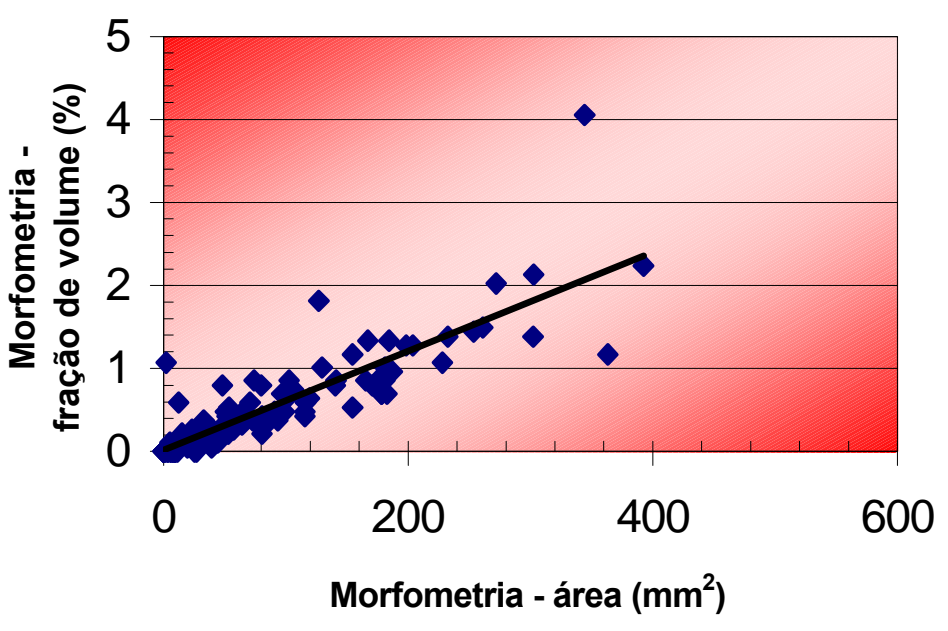

FIGURA 6 - Diagrama de dispersão entre morfometria por área e morfometria por fração de volume (coeficiente de correlação de Pearson) 


\subsection{Análise da associação entre a classificação da eosinofilia tecidual e as demais variáveis de estudo}

Aplicando-se o teste de associação pelo qui-quadrado para a verificação de relação entre a eosinofilia tecidual (segundo morfometria por área) e as demais características clínicas e microscópicas analisadas, observou-se uma associação estatisticamente significativa com o infiltrado inflamatório mononuclear e com a localização do infiltrado inflamatório eosinofílico.

Embora a maioria dos casos tenha apresentado um infiltrado inflamatório mononuclear intenso $(67,2 \%)$, houve uma tendência a um aumento na intensidade da eosinofilia tecidual à medida que aumentava a intensidade do infiltrado inflamatório mononuclear $(p<0,05)$, destacando o fato de que $83,33 \%$ dos tumores com eosinofilia intensa, também apresentavam um infiltrado inflamatório mononuclear intenso (Tabela 9, Figuras 7A, 7B, 8A e 8B).

Tabela 9 - Avaliação da associação entre classificação da eosinofilia tecidual e infiltrado inflamatório mononuclear (teste de associação pelo qui-quadrado)

\begin{tabular}{|c|c|c|c|c|}
\hline \multirow[b]{3}{*}{ INFMN } & \multicolumn{3}{|c|}{ Classificação da Eosinofilia } & \multirow{3}{*}{$\begin{array}{c}\text { TOTAL } \\
\mathbf{1}\end{array}$} \\
\hline & $\mathbf{D}$ & $\mathbf{M}$ & $\mathbf{I}$ & \\
\hline & $\begin{array}{ll}1 & (\%)\end{array}$ & $\begin{array}{ll}1 & (\%)\end{array}$ & $\begin{array}{ll}1 & (\%)\end{array}$ & \\
\hline $\mathbf{D}$ & $9(21,43)$ & $4(9,76)$ & $1(2,38)$ & 14 \\
\hline $\mathbf{M}$ & $13(30,95)$ & $8(19,51)$ & $6(14,29)$ & 27 \\
\hline $\mathbf{I}$ & $20(47,62)$ & $29(70,73)$ & $35(83,33)$ & 84 \\
\hline TOTAL & 42 & 41 & 42 & 125 \\
\hline
\end{tabular}



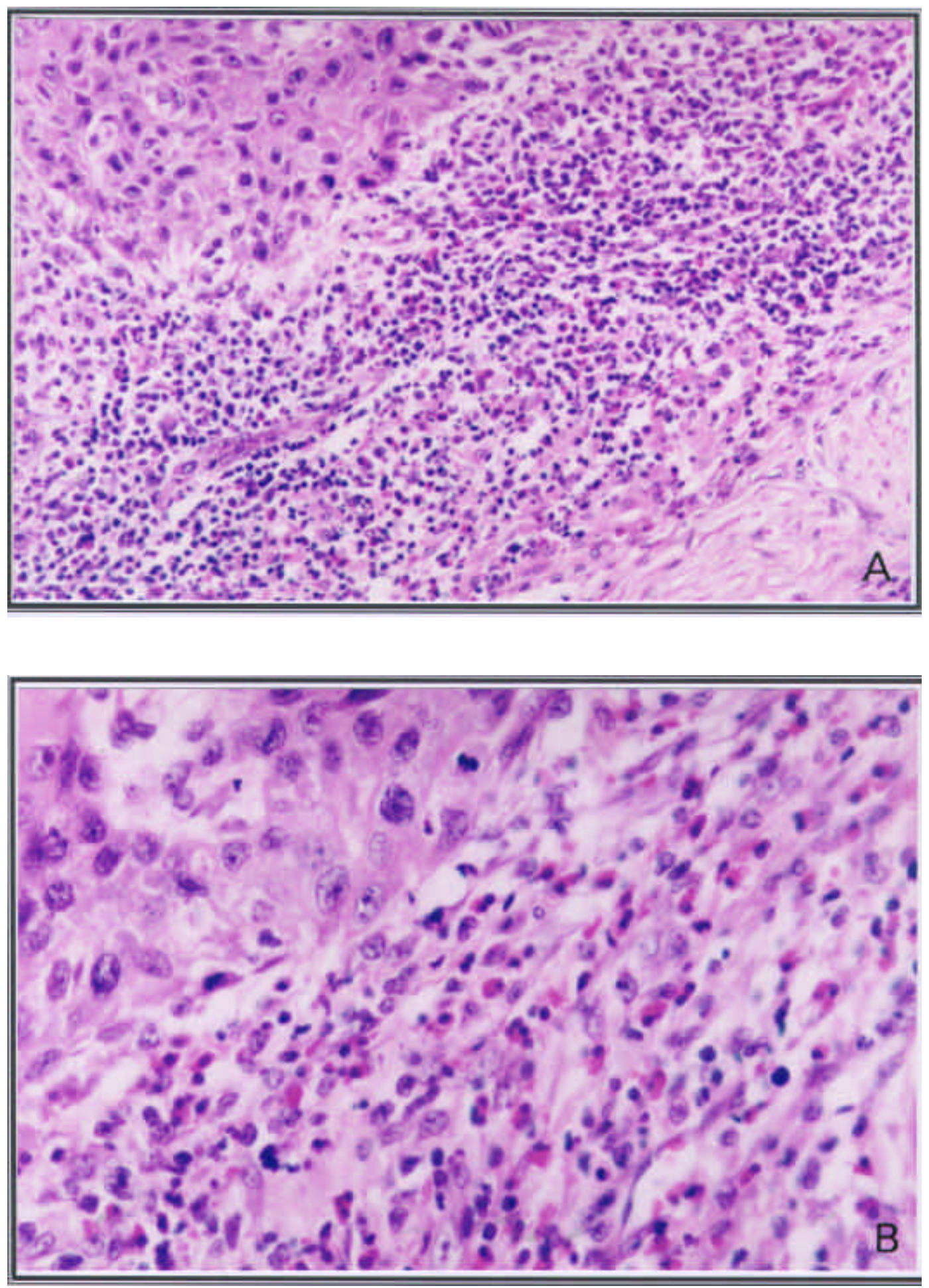

FIGURA 7 - Associação entre infiltrado inflamatório mononuclear intenso e eosinofilia tecidual intensa em carcinomas espinocelulares de boca (HE; aumento original em $A=200 \times$ e em $B=400 \times$ ) 

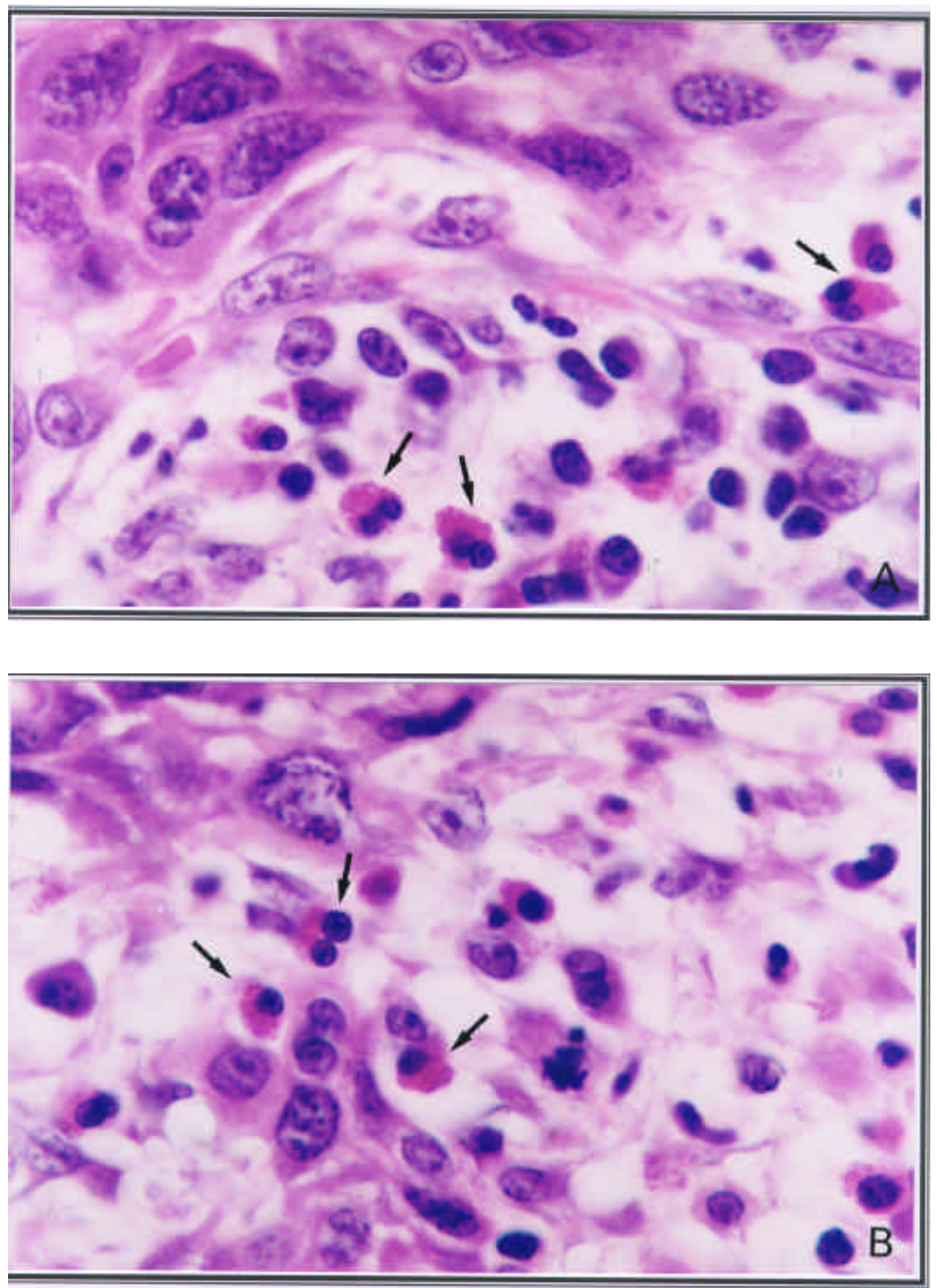

FIGURA 8 - Detalhe da Figura 7, destacando-se a presença dos eosinófilos com núcleo bilobulado e grânulos citoplasmáticos fortemente corados pela eosina (setas) (HE; aumento original em A e B = 1000 $\times$ ) 
Quanto à localização do infiltrado inflamatório eosinofílico, foi demonstrada uma associação estatisticamente significativa $(p<0,001)$ com a intensidade da eosinofilia tecidual. Houve uma tendência à infiltração exclusivamente do estroma tumoral nos casos em que a eosinofilia era discreta $(73,81 \%)$ ou moderada $(60,98 \%)$ e uma tendência à infiltração tanto do estroma, como do parênquima tumoral quando a eosinofilia era intensa $(71,43 \%)$. Como já previsto, nenhum dos casos analisados apresentou infiltração somente do parênquima tumoral (Tabela 10).

TABELA 10 - Avaliação da associação entre eosinofilia tecidual e localização do infiltrado inflamatório eosinofílico (teste de associação pelo qui-quadrado)

\begin{tabular}{|c|c|c|c|c|}
\hline \multirow[b]{3}{*}{ LOCEO } & \multicolumn{3}{|c|}{ Classificação Eosinofilia } & \multirow{3}{*}{$\begin{array}{c}\text { TOTAL } \\
\mathbf{1}\end{array}$} \\
\hline & $\mathbf{D}$ & $\mathbf{M}$ & $\mathbf{I}$ & \\
\hline & $1 \quad(\%)$ & $1 \quad(\%)$ & $1 \quad(\%)$ & \\
\hline $\mathbf{P}$ & $0(0)$ & $0(0)$ & $0(0)$ & 0 \\
\hline $\mathbf{E}$ & $31(73,81)$ & $25(60,98)$ & $12(28,57)$ & 68 \\
\hline$P+E$ & $11(26,19)$ & $16(39,02)$ & $30(71,43)$ & 57 \\
\hline TOTAL & 42 & 41 & 42 & 125 \\
\hline
\end{tabular}

LOCEO: localização do infiltrado inflamatório eosinofílico; D: discreto; M: moderado; I: intenso; P: parênquima; E: estroma 


\subsection{Comparação entre os métodos qualitativo e quantitativo de classificação da eosinofilia tecidual}

$\mathrm{Na}$ avaliação da concordância entre os métodos qualitativo e quantitativo de classificação da eosinofilia tecidual tumoral, foi observada uma porcentagem de concordância bruta de $60 \%$ e uma concordância líquida $(K)$ igual a 0,40 ( $p<0,001)$, a qual corresponde a uma concordância regular segundo a escala de LANDIS; $\mathrm{KOCH}^{38}$. Isso significa que, excluindo-se o efeito do acaso, os dois métodos concordam em $40 \%$ dos casos (Tabela 11).

TABELA 11 - Avaliação da concordância entre o método qualitativo e quantitativo de classificação da eosinofilia tecidual (estatística Kappa)

\begin{tabular}{|c|c|c|c|c|}
\hline \multirow[b]{3}{*}{ INFEO } & \multicolumn{3}{|c|}{ Classificação Eosinofilia (método quantitativo) } & \multirow{3}{*}{$\begin{array}{c}\text { TOTAL } \\
\mathbf{1}\end{array}$} \\
\hline & D & M & I & \\
\hline & $\begin{array}{ll}1 & (\%)\end{array}$ & $\begin{array}{ll}1 & (\%)\end{array}$ & $\begin{array}{ll}1 & (\%)\end{array}$ & \\
\hline D & $34(80,95)$ & $16(30,02)$ & $7(16,67)$ & 57 \\
\hline M & $7(16,67)$ & $22(53,66)$ & $16(38,10)$ & 45 \\
\hline $\mathbf{I}$ & $1(2,38)$ & $3(7,32)$ & $19(45,24)$ & 23 \\
\hline TOTAL & 42 & 41 & 42 & 125 \\
\hline
\end{tabular}




\subsection{Análise de sobrevida}

Ao final do período de seguimento, 30 pacientes (24\%) estavam vivos e sem evidências de recidiva da doença, um $(0,8 \%)$ estava vivo, porém com recidiva tumoral, oito $(6,4 \%)$ foram a óbito no período pós-operatório, 51 (40,8\%) morreram em conseqüência do câncer e 35 (28\%) morreram por outras causas não relacionadas ao tumor.

A sobrevida livre de doença variou de 0 a 287,4 meses, sendo a média igual a 137,9 e a mediana igual a 80,2 meses. A sobrevida global variou de 0 a 287,4 meses, sendo a média igual a 88,2 e a mediana igual a 40,1 meses.

A Tabela 12 ilustra as probabilidades de sobrevida acumulada de SLD após 12, 24 e 60 meses de seguimento. A única variável com significância estatística foi a eosinofilia tecidual. Observou-se que para um paciente com eosinofilia tecidual discreta a probabilidade de sobrevida acumulada após 12 meses foi de $70 \%$, após 24 meses foi de $54 \%$, caindo para $32 \%$ após 60 meses de seguimento. Para um paciente com eosinofilia tecidual intensa, estas probabilidades foram respectivamente, $80 \%, 80 \%$ e $72 \%$. 
TABELA 12 - Análise de sobrevida livre de doença. Porcentagem de sobrevida acumulada pela técnica de Kaplan-Meier

\begin{tabular}{|c|c|c|c|c|c|}
\hline \multirow{2}{*}{ Variável } & \multirow{2}{*}{ Categoria } & \multicolumn{3}{|c|}{ Probabilidade de sobrevida acumulada } & \multirow{2}{*}{$\mathbf{p}^{*}$} \\
\hline & & $12 \mathrm{~m}$ & $24 m$ & $60 \mathrm{~m}$ & \\
\hline \multirow{3}{*}{ Idade } & $<40$ anos & 75 & 62 & 50 & \multirow{3}{*}{0,684} \\
\hline & 40 a 65 anos & 74 & 66 & 54 & \\
\hline & $>65$ anos & 61 & 57 & 42 & \\
\hline \multirow{2}{*}{ Sexo } & Masculino & 71 & 66 & 50 & \multirow{2}{*}{0,905} \\
\hline & Feminino & 68 & 51 & 51 & \\
\hline \multirow{2}{*}{ Tabagismo } & Não & 87 & 58 & 39 & \multirow{2}{*}{0,927} \\
\hline & Sim & 67 & 61 & 49 & \\
\hline \multirow{2}{*}{ Etilismo } & Não & 73 & 64 & 49 & \multirow{2}{*}{0,489} \\
\hline & $\operatorname{Sim}$ & 67 & 60 & 47 & \\
\hline \multirow{2}{*}{ Local do tumor } & Língua + Assoalho & 70 & 62 & 50 & \multirow{2}{*}{0,966} \\
\hline & Outros & 75 & 68 & 51 & \\
\hline \multirow{2}{*}{ Estadiamento T } & $1+2$ & 76 & 67 & 52 & \multirow{2}{*}{0,510} \\
\hline & 3 & 61 & 55 & 48 & \\
\hline \multirow{2}{*}{ Estadiamento $\mathrm{N}$} & 0 & 72 & 65 & 56 & \multirow{2}{*}{0,464} \\
\hline & 1 & 69 & 61 & 45 & \\
\hline \multirow{2}{*}{ Mitoses atípicas } & Discreta + Moderada & 71 & 64 & 51 & \multirow{2}{*}{0,830} \\
\hline & Intensa & 68 & 58 & 47 & \\
\hline Embolização & Ausente & 71 & 60 & 52 & \multirow{2}{*}{0,550} \\
\hline Vascular & Presente & 71 & 65 & 49 & \\
\hline \multirow{3}{*}{$\begin{array}{l}\text { Intıltraçao } \\
\text { Perineural }\end{array}$} & Ausente & 76 & 72 & 72 & \multirow{2}{*}{0,197} \\
\hline & Presente & 69 & 60 & 47 & \\
\hline & Discreta & 70 & 54 & 32 & \multirow{3}{*}{0,024} \\
\hline \multirow[t]{2}{*}{ Eosinofilia } & Moderada & 62 & 53 & 44 & \\
\hline & Intensa & 80 & 80 & 72 & \\
\hline TOTAL & & 71 & 63 & 51 & \\
\hline
\end{tabular}

p* = nível descritivo do teste log-rank 
A comparação entre as curvas de sobrevida livre de doença referentes à eosinofilia discreta, moderada e intensa pode ser observada na Figura 9, tendo apresentado uma diferença estatisticamente significativa $(p=0,024)$.

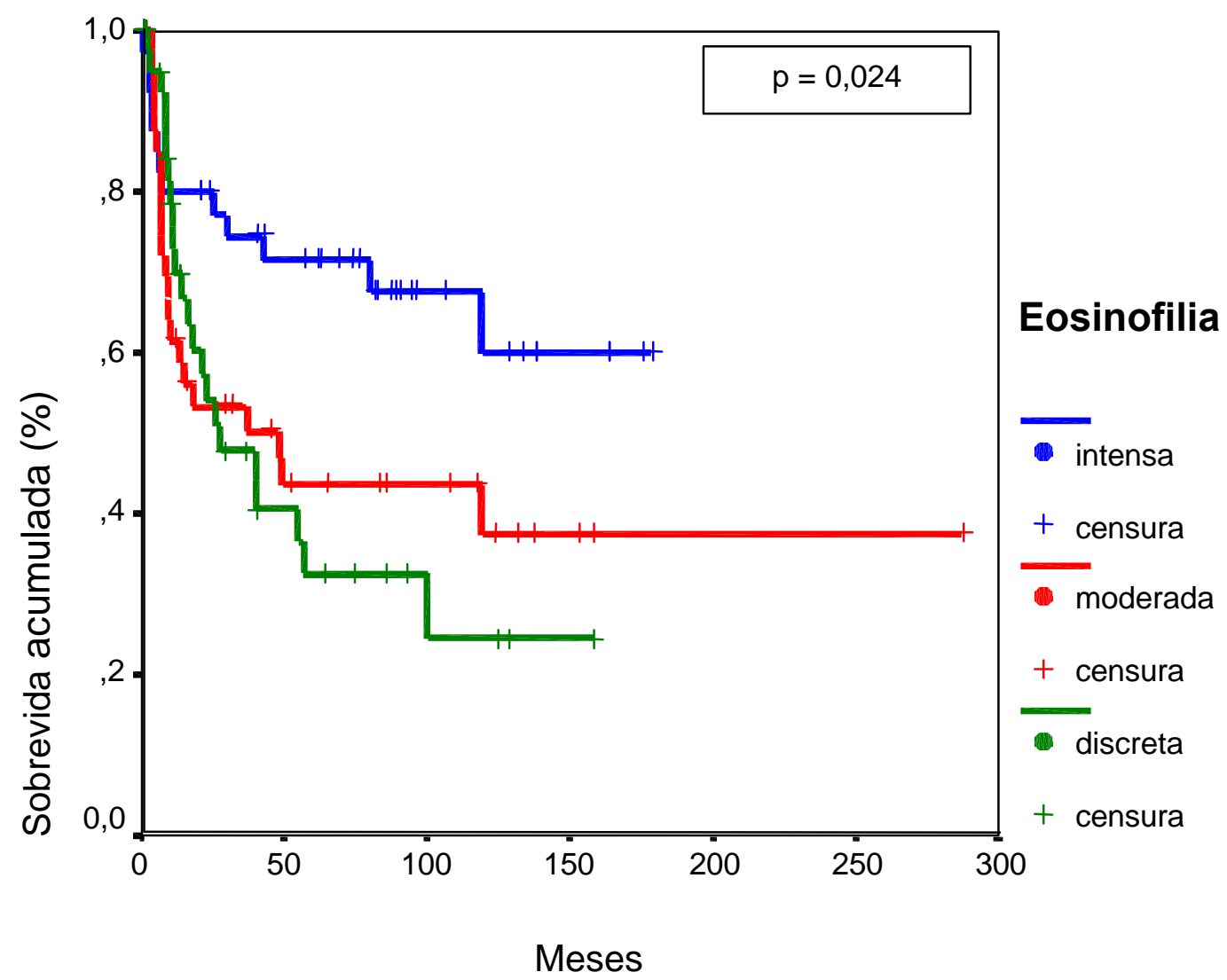

FIGURA 9 - Influência da eosinofilia tecidual na sobrevida livre de doença em pacientes com carcinoma espinocelular de boca

A Tabela 13 ilustra as probabilidades de sobrevida global acumulada (SG) após 12, 24 e 60 meses de seguimento. Novamente, a única variável com significância estatística foi a eosinofilia tecidual. Nos pacientes com eosinofilia tecidual discreta, as probabilidades de sobrevida acumulada aos 12, 24 e 60 meses foram de $81 \%$, $59 \%$ e $27 \%$, respectivamente, enquanto nos pacientes com eosinofilia tecidual intensa os valores foram de $88 \%, 73 \%$ e $63 \%$, respectivamente. 
TABELA 13 - Análise de sobrevida global. Porcentagem de sobrevida acumulada pela técnica de Kaplan-Meier

\begin{tabular}{|c|c|c|c|c|c|}
\hline \multirow{2}{*}{ Variável } & \multirow{2}{*}{ Categoria } & \multicolumn{3}{|c|}{ Probabilidade de sobrevida acumulada } & \multirow{2}{*}{$\mathbf{p}^{*}$} \\
\hline & & $12 \mathrm{~m}$ & $24 m$ & $60 m$ & \\
\hline \multirow{3}{*}{ Idade } & $<40$ anos & 87 & 75 & 50 & \multirow{3}{*}{0,190} \\
\hline & 40 a 65 anos & 85 & 66 & 45 & \\
\hline & $>65$ anos & 69 & 51 & 34 & \\
\hline \multirow{2}{*}{ Sexo } & Masculino & 82 & 62 & 43 & \multirow{2}{*}{0,437} \\
\hline & Feminino & 75 & 65 & 40 & \\
\hline \multirow{2}{*}{ Tabagismo } & Não & 75 & 62 & 37 & \multirow{2}{*}{0,560} \\
\hline & Sim & 80 & 60 & 40 & \\
\hline \multirow{2}{*}{ Etilismo } & Não & 82 & 60 & 41 & \multirow{2}{*}{0,749} \\
\hline & Sim & 80 & 60 & 39 & \\
\hline \multirow{2}{*}{ Local do tumor } & Língua + Assoalho & 82 & 66 & 44 & \multirow{2}{*}{0,612} \\
\hline & Outros & 74 & 42 & 32 & \\
\hline \multirow{2}{*}{ Estadiamento T } & $1+2$ & 82 & 68 & 44 & \multirow{2}{*}{0,701} \\
\hline & 3 & 78 & 51 & 39 & \\
\hline \multirow{2}{*}{ Estadiamento $\mathrm{N}$} & 0 & 80 & 63 & 48 & \multirow{2}{*}{0,651} \\
\hline & 1 & 81 & 62 & 36 & \\
\hline \multirow{2}{*}{ Mitoses atípicas } & Discreta + Moderada & 80 & 62 & 43 & \multirow{2}{*}{0,842} \\
\hline & Intensa & 85 & 65 & 40 & \\
\hline Embolização & Ausente & 76 & 65 & 48 & \multirow{2}{*}{0,167} \\
\hline Vascular & Presente & 83 & 61 & 39 & \\
\hline Infiltração & Ausente & 81 & 62 & 49 & \multirow{2}{*}{0,701} \\
\hline \multirow[t]{2}{*}{ Perineural } & Presente & 80 & 63 & 38 & \\
\hline & Discreta & 81 & 59 & 27 & \multirow{3}{*}{0,015} \\
\hline \multirow[t]{2}{*}{ Eosinofilia } & Moderada & 71 & 56 & 37 & \\
\hline & Intensa & 88 & 73 & 63 & \\
\hline TOTAL & & 81 & 63 & 42 & \\
\hline
\end{tabular}

$\mathrm{p}^{*}=$ nível descritivo do teste log-rank 
A comparação entre as curvas de sobrevida global referentes à eosinofilia discreta, moderada e intensa pode ser observada na Figura 10, tendo apresentado uma diferença estatisticamente significativa $(p=0,015)$.

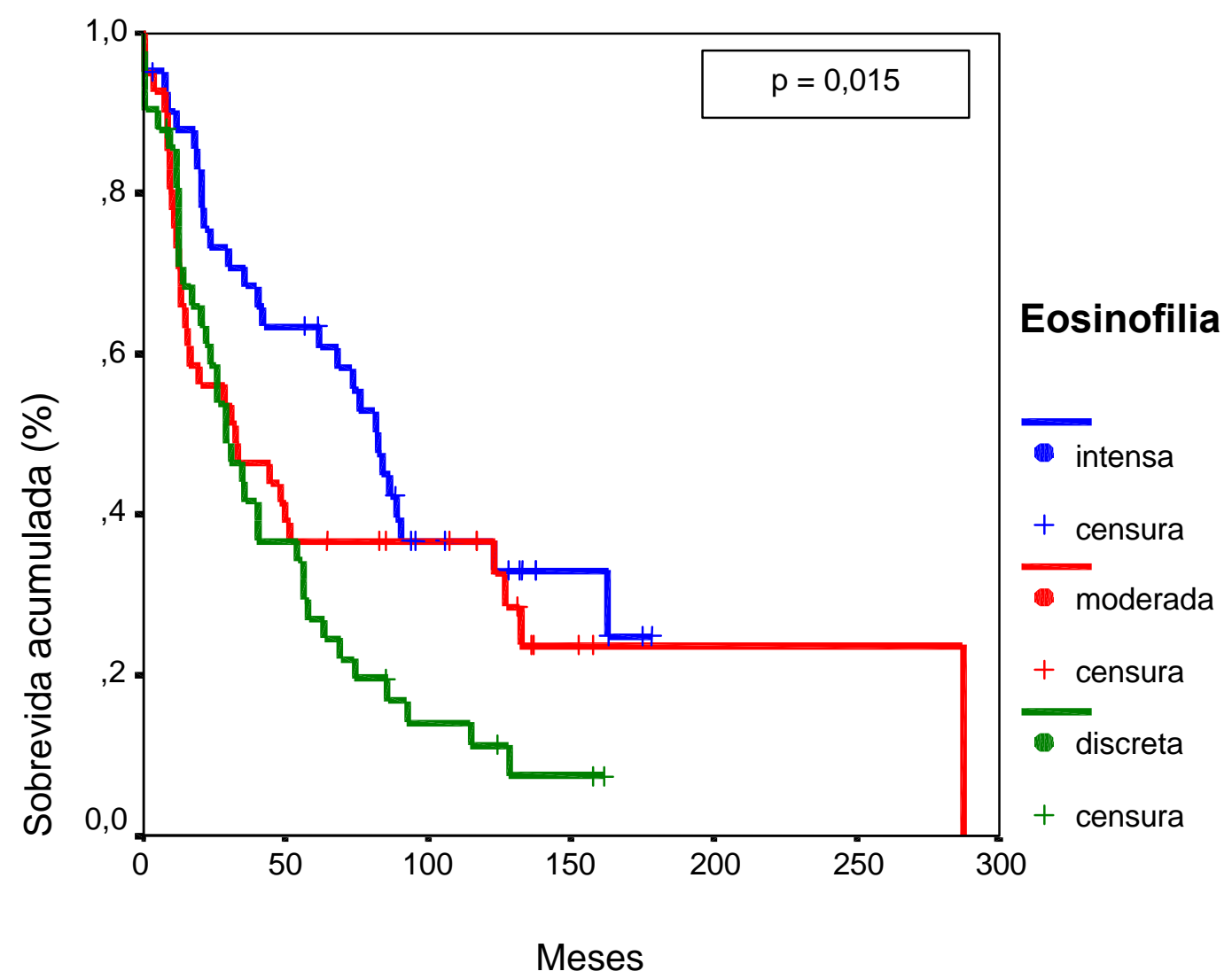

FIGURA 10 - Influência da eosinofilia tecidual na sobrevida global em pacientes com carcinoma espinocelular de boca

A Tabela 14 mostra a análise conjunta da eosinofilia tecidual em relação à SLD e SG pelo modelo de Cox. Verifica-se que um paciente com eosinofilia tecidual discreta ou moderada tem pouco mais de duas vezes o risco de ter recidiva quando comparado com um paciente com eosinofilia intensa, independentemente de idade, sexo, tabagismo, etilismo, 
localização do tumor, estadiamento clínico $\mathrm{T}$ e $\mathrm{N}$ e ocorrência de embolização vascular (sangüínea ou linfática).

Também pôde-se verificar que um paciente com eosinofilia discreta tem um risco de morrer de 2,10 vezes maior do que o risco de um paciente com eosinofilia intensa. Este risco cai para 1,81 para os pacientes com eosinofilia moderada. Esses dois riscos são independentes de idade, sexo, tabagismo, etilismo, localização do tumor, estadiamento clínico T e N e ocorrência de embolização vascular (sangüínea ou linfática).

TABELA 14 - Análise da eosinofilia tecidual por meio do modelo de Cox

\begin{tabular}{cccccccccc}
\hline \hline \multirow{2}{*}{$\begin{array}{c}\text { Eosinofilia } \\
\text { tecidual }\end{array}$} & \multicolumn{3}{c}{ Sobrevida livre de doença } & \multicolumn{4}{c}{ Sobrevida global } \\
\cline { 2 - 9 } & HR bruta & ${ }^{*} \mathrm{HR}$ aj. & IC (HR aj.) & $\mathrm{p}$ & HR bruta & ${ }^{*} \mathrm{HR}$ aj. & IC (HR aj.) & $\mathrm{p}$ \\
\hline Discreta & 2,42 & 2,44 & {$[1,17 ; 5,12]$} & 0,0179 & 2,11 & 2,10 & {$[1,20 ; 3,66]$} & 0,0087 \\
Moderada & 2,19 & 2,51 & {$[1,21 ; 5,18]$} & 0,0132 & 1,48 & 1,81 & {$[1,02 ; 3,20]$} & 0,0423 \\
Intensa & 1 & 1 & & & 1 & 1 & & \\
\hline \hline
\end{tabular}

HR aj. = hazard ratio ajustado por idade, sexo, tabagismo, etilismo, local do tumor, estadiamento clínico T, estadiamento clínico $\mathrm{N}$ e embolização vascular; IC= intervalo de confiança 
6 DISCUSSÃO 


\section{DISCUSSÃO}

A determinação do prognóstico dos carcinomas espinocelulares de boca, mesmo com os crescentes avanços diagnósticos e terapêuticos em oncologia, tem se baseado nas características clínicas e microscópicas tumorais, levando-se em consideração a história natural da neoplasia, o grau de diferenciação celular e o estadiamento clínico, além de fatores como a idade do paciente e sua condição clínica geral, entre outros. Entretanto, estes fatores demonstram um valor limitado na previsão da evolução da doença ${ }^{66}$.

Assim sendo, a busca por características clínicas e/ou microscópicas que possam influenciar o prognóstico das neoplasias malignas continua sendo o objetivo final de muitos trabalhos científicos realizados com o intuito de se conhecer melhor não somente a biologia da célula tumoral e sua capacidade de invasão e disseminação tecidual, mas principalmente as diferentes respostas do hospedeiro frente a estes tumores.

Nossos resultados relativos à análise das características clínicas dos pacientes portadores de carcinoma espinocelular de boca, com estadiamento clínico II e III, localizados na língua, assoalho bucal, área retromolar e gengiva inferior revelaram um perfil já bem estabelecido da doença no Brasil.

Observou-se o acometimento predominante de pacientes do sexo masculino (84\%), da raça branca $(90,4 \%)$ e com idade avançada (média igual a 58 anos). O tabagismo 
e etilismo constituíram fatores de risco presentes na maioria de nossa amostra, relatados por $84 \%$ e $67,2 \%$ dos pacientes, respectivamente, sendo $64 \%$ tabagistas e etilistas simultaneamente.

O local mais acometido pelo carcinoma espinocelular foi a língua, seguida do assoalho bucal, área retromolar e gengiva inferior. Todas estas características seguem, com discretas diferenças, a mesma tendência observada nos dados levantados por SOUZA et al. ${ }^{59}, 1996$, ARAÚJO FILHO et al. ${ }^{3}, 1998$, CAMARINI ${ }^{8}, 1999$, e SANTANA et al. ${ }^{54}, 1999$.

Quanto aos aspectos microscópicos, a maioria dos tumores apresentava pleomorfismo e hipercromatismo moderados e presença discreta de mitoses atípicas. Observou-se uma alta freqüência de infiltração tumoral perineural $(70,4 \%)$ e muscular $(84,8 \%)$ e a ocorrência de um infiltrado inflamatório constituído principalmente por células mononucleares distribuídas difusamente no estroma tumoral, refletindo a resposta do hospedeiro frente à presença das células neoplásicas. No entanto, dentre todas as características microscópicas estudadas, maior ênfase foi dada à avaliação da infiltração tumoral por eosinófilos, a qual tem suscitado inúmeros questionamentos na literatura.

A própria definição de eosinofilia tecidual tem sido objeto de controvérsia. LEIGHTON et al. ${ }^{39}, 1996$, caracterizaram a eosinofilia tecidual associada a tumores (TATE) como a infiltração do estroma tumoral por eosinófilos não relacionada à presença de necrose e/ou ulceração. Apesar de alguns autores como LOWE; FLETCHER ${ }^{41}$, 1984, LOOI $^{40}, 1987$ e LEIGHTON et al. ${ }^{39}, 1996$, terem, da mesma forma, descartado as áreas de necrose e/ou ulceração na avaliação da eosinofilia tecidual nas neoplasias, este critério não tem sido unanimemente utilizado ${ }^{14,15,19,23,24,27,47,65}$. A nossa opção por excluir as áreas de necrose e ulceração extensas decorreu do fato destas características impossibilitarem uma análise microscópica satisfatória e, embora não quantificadas, constatamos, em 
concordância com $\mathrm{LOOI}^{40}$, que estas áreas não necessariamente apresentavam-se infiltradas por eosinófilos.

Além disso, verificamos em $45,6 \%$ dos carcinomas espinocelulares de boca analisados que a presença dos eosinófilos não restringia-se ao infiltrado inflamatório, mas ocorria simultaneamente no parênquima e estroma tumorais, algumas vezes em íntima associação com as células neoplásicas como previamente descrito por LOOI ${ }^{40}$, em 1987.

Os critérios utilizados para a graduação da eosinofilia tecidual nos tumores da região de cabeça e pescoço também têm variado amplamente, como observado na Tabela 15. A classificação da eosinofilia intensa varia desde valores maiores de $\operatorname{dez}^{55}$ a valores maiores de cem eosinófilos em média por campo microscópico ${ }^{39,41}$. Somando-se a isso, a omissão de dados relevantes como o aumento em que os cortes microscópicos são examinados (Tabela 15) e o número de campos ou a área percorridos ${ }^{23,27,39,40,41,47,55,65}$, tornam inviável a comparação entre os resultados obtidos.

Diante de critérios tão discrepantes, também pode-se questionar a influência da utilização de diferentes colorações na identificação dos eosinófilos. Enquanto DESSY et al. ${ }^{15}$ e DERON; GOOSENS; HALAMA ${ }^{14}$ empregaram a coloração de Giemsa, considerada mais específica para os eosinófilos ${ }^{14}$, e ONO et al. ${ }^{46}$ utilizaram a coloração de Luna, os demais autores optaram pela Hematoxilina-Eosina ${ }^{23,24,27,39,40,55,65}$. Até que ponto isso poderia interferir nos resultados? É realmente necessária a coloração especial? Segundo SASSLER et al. ${ }^{55}$, a variação na contagem dos eosinófilos por diferentes patologistas é esperada, contudo deve ser mínima já que são células facilmente identificadas em função da intensa coloração dos seus grânulos citoplasmáticos pela eosina. Complementando esta observação, o estudo de FERNÁNDEZ-ACEÑERO ${ }^{18}$ sobre a influência da eosinofilia tecidual em carcinomas colorretais, demonstrou que apesar da coloração de Giemsa melhorar a detecção dos eosinófilos degranulados, os quais podem não ser identificados em 
HE, não se observa uma modificação significativa na distribuição das contagens altas ou baixas destas células quando utilizada a coloração de rotina. Portanto, optamos por realizar a contagem dos eosinófilos em HE em função desta ser uma coloração capaz de evidenciálos com clareza e de ser rotineiramente utilizada nos laboratórios de patologia geral e bucal, sem os custos adicionais do emprego de colorações especiais.

Além disso, constatamos que a avaliação da eosinofilia tecidual baseada em biópsias, realizada por $\mathrm{LOOI}^{40}$, 1987, HORIUCHI et al. ${ }^{27}, 1993$, THOMPSON; BRADLEY; GRIFFIN ${ }^{65}$, 1994, DERON; GOOSSENS; HALAMA ${ }^{14}$, 1996, LEIGHTON et al. ${ }^{39}, 1996$ e SASSLER et al. ${ }^{55}, 1996$, pode não refletir fielmente a ocorrência da TATE, já que no nosso estudo, utilizando peças cirúrgicas, o front de invasão tumoral constituiu o local de maior concentração dos eosinófilos e os espécimes provenientes de biópsias incisionais geralmente apresentam pequenos tamanhos, representativos apenas das porções mais superficiais do tumor.

Embora a metodologia utilizada neste estudo também se diferencie das demais metodologias empregadas na avaliação da eosinofilia tecidual nos tumores da região de cabeça e pescoço, ela visa atingir alguns objetivos bem definidos. Com a realização da morfometria para a mensuração da eosinofilia tecidual nos carcinomas espinocelulares de boca, procuramos minimizar ao máximo a subjetividade da análise, a fim de permitir a sua reprodução e comparação com os resultados de futuros trabalhos. Associada a isso, a análise de 75 campos microscópicos em cada caso, distribuídos aleatoriamente desde as porções mais superficiais do tumor até os planos profundos, com um aumento de $800 \times$, nos permitiu um registro mais fiel da ocorrência dos eosinófilos em relação aos demais estudos relativos à eosinofilia tecidual em tumores de cabeça e pescoço disponíveis na literatura (Tabela 15). 
TABELA 15 - Diferentes critérios utilizados para a classificação da eosinofilia tecidual nos tumores malignos da região de cabeça e pescoço

\begin{tabular}{|c|c|c|c|c|c|c|}
\hline \multirow{2}{*}{ Autor } & \multirow{2}{*}{ Aumento } & \multicolumn{5}{|c|}{ Número de eosinófilos por campo } \\
\hline & & Ausente & Discreta & Moderada & Intensa & Maciça \\
\hline $\begin{array}{l}\text { LOWE; } \\
\text { FLETCHER }^{41} \text { (1984) }\end{array}$ & $\begin{array}{l}\text { Grande } \\
\text { aumento }\end{array}$ & & & $>10$ & $>100$ & \\
\hline $\begin{array}{l}\text { PASTRÒÁK; } \\
\text { JANSA }^{47} \text { (1984) }\end{array}$ & & & Poucos & $\begin{array}{l}\text { Muitos } \\
\text { (distribuição } \\
\text { focal) }\end{array}$ & $\begin{array}{l}>50 \% \text { do } \\
\text { infiltrado } \\
\text { inflamatório }\end{array}$ & \\
\hline $\begin{array}{l}\text { DESSY } \\
(1986)\end{array} \quad$ et $\quad$ al. $^{15}$ & $400 x$ & & $\begin{array}{l}\text { Ausente / } \\
\text { presença } \\
\text { esporádica }\end{array}$ & $\begin{array}{l}\quad>10 \\
\text { (pelo menos } \\
7 \text { campos) }\end{array}$ & $\begin{array}{c}>10 \\
(10 \text { campos })\end{array}$ & \\
\hline $\begin{array}{l}\text { GOLDSMITH; } \\
\text { CRESSON; ASKIN }{ }^{23} \\
(1987)\end{array}$ & & 0 & $5-10$ & $10-20$ & $20-30$ & $>30$ \\
\hline LOOI $^{40}(1987)$ & $\begin{array}{l}\text { Grande } \\
\text { aumento }\end{array}$ & & $>10$ & $\begin{array}{c}>10 \\
(10 \text { campos })\end{array}$ & $>100$ & \\
\hline $\begin{array}{l}\text { GOLDSMITH et al. }{ }^{24} \\
(1992)\end{array}$ & $\begin{array}{l}\text { Grande } \\
\text { aumento }\end{array}$ & $0-2$ & $2-10$ & $10-20$ & $20-30$ & $>30$ \\
\hline $\begin{array}{l}\text { HORIUCHI et al. } \\
(1993)\end{array}$ & & $\begin{array}{c}\text { Não } \\
\text { especificada }\end{array}$ & $\begin{array}{c}\text { Não } \\
\text { especificada }\end{array}$ & $\begin{array}{c}\text { Não } \\
\text { especificada }\end{array}$ & $\begin{array}{c}\text { Não } \\
\text { especificada }\end{array}$ & \\
\hline $\begin{array}{l}\text { THOMPSON; } \\
\text { BRADLEY; } \\
\text { GRIFFIN }^{65}(1994)\end{array}$ & & & $1-5$ & $5-20$ & $>20$ & \\
\hline $\begin{array}{l}\text { SASSLER et } \text { al. }^{55} \\
(1995)\end{array}$ & $\begin{array}{l}\text { Grande } \\
\text { aumento }\end{array}$ & & $1-5$ & $5-10$ & $>10$ & \\
\hline $\begin{array}{l}\text { DERON; } \\
\text { GOOSSENS; } \\
\text { HALAMA }^{14}(1996)\end{array}$ & $750 x$ & & $>2^{*}$ & $>2^{*}$ & $>2^{*}$ & \\
\hline $\begin{array}{l}\text { LEIGHTON et al. } \\
(1996)\end{array}$ & $\begin{array}{l}\text { Grande } \\
\text { aumento }\end{array}$ & & $>10$ & $\begin{array}{c}>10 \\
(10 \text { campos })\end{array}$ & $>100$ & \\
\hline
\end{tabular}

*a eosinofilia tecidual não foi graduada 
A aplicação de dois métodos para a quantificação dos eosinófilos, a morfometria por área e a morfometria por fração de volume, foi realizada com a finalidade de detectarmos discrepâncias entre ambos. Contudo, a partir da correlação de 0,87 observada pelo coeficiente de correlação de Pearson, concluímos que ambos os métodos são equivalentes na determinação da eosinofilia tecidual e, portanto, adotamos preferencialmente a morfometria por área para a classificação da TATE.

A divisão do número de eosinófilos obtidos nos 125 pacientes em tercis nos possibilitou delimitar e contrastar as duas extremidades (discreta e intensa) da TATE nos carcinomas espinocelulares de boca, o que constituiu um passo importante para a avaliação posterior da intensidade da eosinofilia tecidual como fator prognóstico nestes tumores. A eosinofilia foi classificada como discreta quando se observavam, no máximo, 26 eosinófilos por milímetro quadrado, como moderada quando se observavam 27 a 83 eosinófilos por milímetro quadrado e, como intensa, quando os tumores apresentavam valor igual ou maior que 84 eosinófilos por milímetro quadrado. Mais uma vez, reafirmamos a impossibilidade de estabelecermos critérios de comparação destes valores apresentados com os resultados dos estudos precedentes sobre a eosinofilia tecidual na região de cabeça e pescoço ${ }^{14,15,23,24,27,39,40,41,47,55,65}$.

Contudo, deve ser ressaltado que os valores de referência para eosinofilia tecidual discreta, moderada e intensa obtidos, embora permitam demonstrar o efeito de altos valores de eosinófilos na sobrevida dos pacientes, ainda não devem ser interpretados como valores de corte clinicamente relevantes, sendo necessários mais estudos para sua confirmação. Portanto, apesar da análise qualitativa da eosinofilia tecidual ter apresentado uma concordância líquida de $40 \%$ com a análise quantitativa, índice este a princípio insatisfatório e considerado regular, segundo a classificação de LANDIS; $\mathrm{KOCH}^{38}$, a 
viabilidade da sua utilização na rotina laboratorial para a determinação da eosinofilia tecidual não deve ainda ser descartada, merecendo uma reavaliação.

Entre todas as variáveis estudadas, observou-se uma associação estatisticamente significativa da eosinofilia tecidual com a localização do infiltrado inflamatório eosinofílico ( $p<0,001)$ e com o infiltrado inflamatório mononuclear $(p<0,05)$, sendo esta última também compartilhada por SASSLER et al. ${ }^{55}, 1996$. Sabendo-se que os eosinófilos se valem para sua adesão e transmigração da via VLA-4/VCAM-1, comum aos linfócitos e monócitos ${ }^{50}$, este poderia ser um dos mecanismos utilizados para a mobilização conjunta destas células. Por outro lado, este achado vai de encontro com a hipótese bastante difundida de que a eosinofilia tecidual faça parte de uma resposta imunológica dependente de linfócitos $T^{50,53,5771}$, já que várias citocinas derivadas dos linfócitos como a LCF, IL-2, IL-3, IL-5, GM-CSF e RANTES têm sido consideradas importantes na quimiotaxia para os eosinófilos ${ }^{50}$. No entanto, dentre estas citocinas, a IL-5, produzida especificamente por subpopulações Th $2^{69,70}$, tem sido especialmente envolvida na atração dos eosinófilos ${ }^{53}$. Além disso, a IL-4, uma citocina também derivada de linfócitos Th2, parece regular a expressão da VCAM-1, aumentando a transmigração dos eosinófilos através do endotélio pela interação VLA-4/VCAM-1, uma via que não é utilizada pelos neutrófilos ${ }^{21,50,63,69}$.

Todas estas considerações poderiam representar uma resposta parcial para o acúmulo seletivo de eosinófilos em determinadas situações, já que um infiltrado inflamatório mononuclear intenso não obrigatoriamente vem acompanhado de uma eosinofilia tecidual intensa, podendo esta ser discreta ou mesmo ausente, como observado em $16 \%$ da nossa amostra. Por outro lado, a via comum VLA-4/VCAM-1 utilizada pelos eosinófilos, linfócitos e monócitos para sua transmigração poderia justificar a ausência de correlação com o 
infiltrado inflamatório neutrofílico observada nos nossos resultados, uma vez que os neutrófilos não se utilizam desta via.

Acredita-se ainda que a dependência dos linfócitos T atribuída aos eosinófilos possa ser transposta pelas próprias células neoplásicas ou por certos tipos de imunoterapia. Nestes casos, hemopoetinas específicas para a linhagem dos eosinófilos, supridas normalmente pelos linfócitos $\mathrm{T}$, seriam fornecidas pelos tecidos neoplásicos ou artificialmente, resultando em uma eosinofilia $\mid$ local $^{57}$. Estas hipóteses induzem ao questionamento sobre quais seriam as células responsáveis pela secreção de fatores eosinofilotáticos: as células do infiltrado inflamatório, do estroma adjacente ou as próprias células neoplásicas? Infelizmente, até o presente momento, não se dispõe da resposta definitiva para este questionamento, o que torna a presença dos eosinófilos nos tumores malignos um achado ainda mais intrigante.

Embora a literatura demonstre uma tendência a considerar a eosinofilia tecidual como um fator de prognóstico favorável nos carcinomas espinocelulares da região de cabeça e pescoço ${ }^{14,15,23,24,65}$, esses resultados devem ser interpretados com cautela. Não somente a diversidade de critérios de definição e graduação da TATE, já discutidos anteriormente, têm impedido conclusões mais consistentes, mas outras variáveis como a localização do tumor, o estadiamento clínico no momento do diagnóstico, a modalidade de tratamento e o período de seguimento dos pacientes, também devem ser relevados quando da investigação de um fator de prognóstico nestas neoplasias.

Considerando-se os tumores malignos de laringe, DESSY et al. ${ }^{15}$, 1986, publicaram um trabalho no qual correlacionaram a presença dos eosinófilos nos carcinomas espinocelulares desta localização com uma evolução clínica favorável. Para chegar a esta conclusão, os autores não se basearam em dados clínicos sobre a evolução dos pacientes, mas sim na observação de que os tumores bem diferenciados (e portanto, supostamente 
com melhor prognóstico) apresentavam quantidades proporcionalmente maiores de eosinófilos no seu estroma, deixando clara a limitação dos resultados apresentados.

Posteriormente, ainda em relação aos tumores da região de laringe, THOMPSON; BRADLEY; GRIFFIN ${ }^{65}$, em 1994, associaram a TATE a um prognóstico favorável, enquanto SASSLER et al..$^{55}$, em 1995, não encontraram influência no prognóstico. Por outro lado, os dois trabalhos dedicados à avaliação da TATE nos tumores de nasofaringe, realizados por $\mathrm{LOOI}^{40}$, em 1987 e LEIGHTON et al. ${ }^{39}$, em 1996, foram unânimes na sua conclusão, não considerando a eosinofilia tecidual como um fator relevante no prognóstico destes tumores.

Em 1984, LOWE; FLETCHER ${ }^{41}$ e PASTRÒÁK; JANSA ${ }^{47}$ avaliaram a eosinofilia tecidual em tumores malignos de origem epitelial em diversas localizações, incluindo a boca. No entanto, a identificação da TATE foi geralmente discreta e em um número restrito de casos, inviabilizando a determinação de sua influência nos carcinomas espinocelulares de boca, embora PASTRÒÁK; JANSA ${ }^{47}$ tenham encontrado uma correlação favorável da eosinofilia tecidual no prognóstico dos carcinomas espinocelulares de cérvix uterino. Posteriormente, GOLDSMITH; CRESSON, ASKIN²3, 1987, GOLDSMITH et al. ${ }^{24}, 1992$, e DERON; GOOSSENS; HALAMA ${ }^{14}, 1996$, avaliaram tumores da região de cabeça e pescoço conjuntamente, estabelecendo a eosinofilia tecidual como um fator de prognóstico favorável. O estudo em conjunto de neoplasias malignas de diferentes localizações como a boca, orofaringe, hipofaringe e laringe, com prognósticos variados, incorre na limitação de não refletir o impacto da eosinofilia tecidual em cada um destes sítios anatômicos individualmente. Além disso, o curto período de acompanhamento (dois anos) nestes trabalhos pode ter influenciado os resultados obtidos. 
Contrariamente às conclusões do estudo de HORIUCHI et al. ${ }^{27}, 1993$, o único a abordar a eosinofilia tecidual estritamente nos carcinomas espinocelulares de boca, observamos uma correlação da TATE intensa com o prognóstico favorável dos pacientes, considerando-se tanto a sobrevida livre de doença, como a sobrevida global. Contudo, no estudo de HORIUCHI et al. ${ }^{27}$, foram avaliados 31 pacientes, um número limitado de casos em comparação aos nossos 125 casos analisados, o que pode ser, em parte, um dos fatores que contribuíram para a diferença nos resultados. Enquanto $\mathrm{HORIUCHI}$ et al. ${ }^{27}$ avaliaram pacientes em sua maioria com estadiamento clínico III e IV, optamos por excluir da nossa análise os pacientes com estadiamento clínico I e IV, nos quais a influência do estadiamento constitui um fator preponderante no prognóstico. Além disso, como a localização anatômica dos tumores constitui uma importante variável relacionada ao prognóstico ${ }^{66}$, restringimos nossa análise aos carcinomas espinocelulares situados na língua, assoalho bucal, gengiva inferior e área retromolar, procurando limitar o número de variáveis que pudessem influenciar na evolução dos pacientes. Assim, a partir da análise dos fatores de prognóstico constatamos que na nossa amostra a eosinofilia tecidual intensa se mostrou um fator de prognóstico favorável independente. Estes resultados nos sugerem que os eosinófilos possam realmente apresentar algum efeito antitumoral nestas neoplasias.

Um dos mecanismos aventados para esta possível função antitumoral dos eosinófilos é a capacidade destas células realizarem $\operatorname{ADCC}^{11,21,43}$, um mecanismo relevante na destruição de alvos celulares ${ }^{11}$ e que poderia mediar a citotoxicidade celular dos eosinófilos contra as células neoplásicas.

Além disso, a produção de IL-5 pelas células do estroma dos tumores poderia ativar os eosinófilos, resultando no prolongamento da sua sobrevida e permitindo sua degranulação com a subseqüente liberação de proteínas dos seus grânulos específicos ${ }^{18}$, 
como a $\mathrm{MBP}^{14,41,63,71}$, a ECP ${ }^{63}$ e a $\mathrm{EPO}^{21,71}$, que agiriam de forma citotóxica contra as células tumorais $^{14,18,63,71}$.

Foi demonstrada por TEPPER, COFFMAN, LEDER ${ }^{64}$, em 1992, uma ação da IL-4 na regressão de tumores em animais experimentais, particularmente mediada por eosinófilos, apesar do exato mecanismo deste achado não ter sido ainda definido.

Também tem sido considerado que algumas citocinas secretadas pelos eosinófilos ativados, incluindo a IL-1, TNF- $\alpha$, IL-3, GM-CSF, TGF- $\beta^{50,57,70,72}$, poderiam contribuir para a citotoxicidade tumoral tanto pela ação direta, como pela ativação autócrina dos eosinófilos ou mesmo pela estimulação de populações adicionais de células efetoras ${ }^{63}$.

Porém, nem sempre as citocinas produzidas pelos eosinófilos têm sido relacionadas com um efeito antitumoral. GHIABI; GALLAGHER; WONG ${ }^{19}$, em 1992, demonstraram que os eosinófilos recrutados para os locais de desenvolvimento de carcinoma espinocelular DMBA induzido em hamsters, em sua maioria, produziam o fator de crescimento transformador-alfa (TGF- $\alpha$ ), uma citocina multifuncional relacionada com atividades biológicas como mitogênese, angiogênese e reabsorção óssea, podendo favorecer o processo de desenvolvimento das neoplasias. Esta hipótese foi também considerada no estudo de WONG et al. ${ }^{74}$, em 1999, no qual foi observado que a eliminação da eosinofilia tecidual resultava em um atraso na detecção clínica inicial, além da redução do crescimento de tumores DMBA induzidos na mucosa bucal de hamsters.

No entanto, a secreção de grandes quantidades de TGF- $\alpha$ e de TGF- $\beta^{70,72}$ também sugere a possibilidade dos eosinófilos apresentarem uma função importante no reparo, na remodelação tecidual e no desenvolvimento de fibrose pós-inflamatória ${ }^{43,70}$. Estas constatações, se transpostas para a função dos eosinófilos nos tumores, poderiam relacionar a atividade desta célula simplesmente com o processo de remodelação tecidual 
decorrente do crescimento tumoral, contrariando a hipótese da sua presença representar uma resposta imunológica direcionada contra as células neoplásicas.

A capacidade de regular os fibroblastos e estimular a síntese de colágeno também tem sido atribuída aos eosinófilos ${ }^{5}$. Desta forma, a infiltração tecidual por eosinófilos poderia ser vantajosa para os pacientes com tumores sólidos, onde o processo de degradação do colágeno, que desempenha um papel importante no crescimento e disseminação tumoral, poderia estar prejudicado. Por isso os eosinófilos estariam associados a uma melhora na sobrevida dos pacientes com tumores sólidos ${ }^{44}$, o que contraria os achados de ONO et al. ${ }^{46}$, 1997, e STÅHLE-BÄCKDAHL; PARKS ${ }^{60}$, 1993, que relacionaram a presença dos eosinófilos nos tumores à síntese de metaloproteinases, consideradas importantes na remodelação tecidual e na invasão tumoral.

Ainda não está claro se a presença dos eosinófilos é indicativa de uma resposta imunológica mais efetiva contra o tumor e a definição da sua função depende do conhecimento das interações celulares e moleculares destas células nos locais dos tumores.

Embora no nosso estudo a eosinofilia tecidual intensa tenha se mostrado um fator de prognóstico favorável independente nos carcinomas espinocelulares com estadiamento clínico II e III, localizados na língua, assoalho bucal, área retromolar e gengiva inferior, será necessária a realização de mais estudos para a confirmação destes resultados, inclusive estendendo-se a amostra avaliada aos demais estádios clínicos e diferentes sítios anatômicos da boca. Entretanto, não podemos deixar de considerar que os resultados referentes ao estudo da eosinofilia tecidual associada aos tumores malignos poderão, no futuro, orientar a determinação do prognóstico destas neoplasias, ou mesmo contribuir na compreensão da biologia tumoral e na busca de terapias alternativas contra o câncer. 
7 CONCLUSÃO 


\section{CONCLUSÃO}

Analisando-se as características clínicas e microscópicas de 125 pacientes portadores de carcinoma espinocelular de boca com estadiamento clínico II e III localizados na língua, assoalho bucal, área retromolar e gengiva inferior, verificamos que:

1. foram acometidos principalmente indivíduos do sexo masculino, da raça branca e com idade avançada, sendo o tabagismo e o etilismo fatores de risco freqüentes;

2. as lesões eram predominantemente ulceroinfiltrativas e a língua foi o local mais comumente acometido;

3. o esvaziamento cervical ipsilateral e a radioterapia foram realizados na maioria dos pacientes;

4. $40,8 \%$ dos pacientes morreram em conseqüência do tumor primário, sendo a média da sobrevida livre de doença igual a 137,9 meses e da sobrevida global 88,2 meses;

5. microscopicamente, a maioria dos tumores apresentava hipercromatismo e pleomorfismo moderados com poucas mitoses atípicas e infiltrado inflamatório mononuclear intenso; 
6. as infiltrações tumoral perineural e muscular foram achados freqüentes;

7. a presença dos eosinófilos nos tumores, quantificada pela análise morfométrica, variou de 0 a 392 eosinófilos por milímetro quadrado, sendo classificada como ausente/discreta quando se observavam 0 a 26 eosinófilos por milímetro quadrado, moderada quando se observavam 27 a 83 eosinófilos por milímetro quadrado e intensa quando se observavam 84 ou mais eosinófilos por milímetro quadrado;

8. existiu uma associação estatisticamente significativa entre a eosinofilia tecidual presente nos tumores com o infiltrado inflamatório mononuclear, bem como com a localização do infiltrado inflamatório eosinofílico;

9. houve uma maior probabilidade de sobrevida acumulada, tanto em relação à sobrevida livre de doença, como em relação à sobrevida global, nos pacientes cujos tumores apresentavam uma eosinofilia tecidual intensa;

10. a eosinofilia tecidual intensa constituiu um fator de prognóstico independente de idade, sexo, tabagismo, etilismo, localização do tumor, estadiamento clínico T e N e ocorrência de embolização vascular (sangüínea ou linfática).

Portanto, a análise dos resultados nos permitiu concluir que a eosinofilia tecidual intensa representa um fator de prognóstico favorável independente em carcinomas espinocelulares de boca com estadiamento clínico II e III localizados na língua, assoalho bucal, área retromolar e gengiva inferior. 
REFERÊNCIAS BIBLIOGRÁFICAS 


\section{REFERÊNCIAS BIBLIOGRÁFICAS}

1. ABBAS, A.K.; LICHTMAN, A.H.; POBER, J.S. Immunity to tumors. In:

Cellular and molecular immunology. 3.ed. Philadelphia, Saunders, 1997. p.382405.

2. ALI, S.; KAUR, J.; PATEL, K.D. Intercellular cell adhesion molecule-1, vascular cell adhesion molecule-1, and regulated on activation normal $\mathrm{T}$ cell expressed and secreted are expressed by human breast carcinoma cells and support eosinophil adhesion and activation. Amer. J. Path., v.157, n.1, p.313-21, July 2000.

3. ARAÚJO FILHO, V.J.F. et al. Perfil de incidência do câncer oral em um hospital geral em São Paulo. Rev. Hosp. clin. Fac. Med. São Paulo, v.53, n.3, p.110-3, maio / jun. 1998.

4. BIGNOLD, L.P. The eosinophil leukocyte: controversies of recruitment and function. Experientia (Basel), v.51, n.4, p.317-27, Apr. 1995.

5. BLUMENTHAL, R.D. et al. Degranulating eosinophils in human endometriosis. Amer. J. Path., v.156, n.5, p.1581-8, May 2000.

\footnotetext{
*Normas recomendadas para uso no âmbito da Universidade de São Paulo, com base no documento "Referências Bibliográficas: exemplos" emanado do Conselho Supervisor do Sistema Integrado de Bibliotecas da USP, em reunião de 20 de setembro de 1990.
} 
6. BRASIL. Ministério da Saúde. Instituto Nacional de Câncer. Câncer de boca. Manual de detecção de lesões suspeitas. 2 ed. Rio de Janeiro, INCA / Pró-Onco, 1996. / Disponível também em http://www.inca.org.br/manual/boca/index.html.

7. BRYNE, M. Prognostic value of various molecular and cellular features in oral squamous cell carcinomas: a review. J. oral Path. Med., v.20, n.9, p.413-20, Oct. 1991.

8. CAMARINI, E.T. Estudo epidemiológico dos carcinomas espinocelulares de boca atendidos nas cidades de Bauru e Jaú, Estado de São Paulo, Brasil. Bauru, 1999. 124p. Dissertação (Mestrado) - Faculdade de Odontologia de Bauru, Universidade de São Paulo.

9. COLLINS, T. Acute and chronic inflammation. In: COTRAN, R.S.; KUMAR, V.; COLLINS, T. Robbins pathologic basis of disease. 6.ed. Philadelphia, Saunders, 1999. p.50-88.

10. COOK, E.B.; STAHL, J.L.; GRAZIANO, F.M. Eotaxin: what we know, and what we would like to know. Allergy Asthma Proc., v.19, n.5, p.253-5, Sept./Oct. 1998.

11. COTRAN, R.S.; KUMAR, V.; COLLINS, T. Diseases of immunity. In: Robbins pathologic basis of disease. 6.ed. Philadelphia, Saunders, 1999. p.188259.

12. COTRAN, R.S.; KUMAR, V.; COLLINS, T. Neoplasia. In: Robbins pathologic basis of disease. 6.ed. Philadelphia, Saunders, 1999. p.260-327.

13. COX, D.R. Regression models and life tables. Statist. Soc., v.34, p.187-92, 1972. 
14. DERON, P.; GOOSSENS, A.; HALAMA, A. R. Tumour-associated tissue eosinophilia in head and neck squamous-cell carcinoma. ORL J. Otorhinolaryngol. Relat. Spec., v.58, n.3, p.167-70, May 1996.

15. DESSY, E et al. Reazione stromale, eosinofilia tessutale e mastocitosi nel carcinoma della laringe. Acta Otorhinolaring. ital., v.6, n.4, p.357-66, giugl. 1986.

16. EHRLICH, P. Ueber die specifischen granulationen des blut. Arch. Anat. Physiol. Lpz. 3, Physiol. Abstr. p.571-79, 1879 apud WARDLAW, A.J.; MOQBEL, R.; KAY, B. ${ }^{68}$ p.151.

17. ESTIMATIVA da incidência e mortalidade por câncer de boca no Brasil. Disponível na internet. http://www.inca.org.br/epidemiologia/estimativa2000/brasil.html. 18/03/2000.

18. FERNÁNDEZ-ACEÑERO, M.J. et al. Prognostic influence of tumor-associated eosinophilic infiltrate in colorectal carcinoma. Cancer (Philad.), v.88, n.7, p.1544-8, Apr. 2000.

19. GHIABI, M.; GALLAGHER G.T.; WONG, D.T.W. Eosinophils, tissue eosinophilia, and eosinophil-derived transforming growth factor $\alpha$ in hamster oral carcinogenesis. Cancer Res., v.52, n.2, p.389-93, Jan. 1992.

20. GIEMBYCZ, M.A.; LINDSAY, M.A. Pharmacology of the eosinophil. Pharmacol. Rev., v.51, n.2, p.213-40, June 1999.

21. GLEICH, G.J.; ADOLPHSON, C.R.; LEIFERMAN, K.M. The biology of the eosinophil leukocyte. Ann. Rev. Med., v.44, p.85-101, 1993. 
22. GLUCKMAN, J. L. et al. Prognostic indicators for squamous cell carcinoma of the oral cavity: a clinicopathologic correlation. Laryngoscope (St. Louis), v.107, n.9, p.123944, Sept. 1997.

23. GOLDSMITH, M.M.; CRESSON, D.H.; ASKIN, F.B. The prognostic significance of stromal eosinophilia in head and neck cancer. Otolaryngol. Head Neck Surg., v.96, n.4, p.319-24, 1987.

24. GOLDSMITH, M. M. et al. The importance of eosinophil in head and neck cancer. Otolaryngol Head Neck Surg., v.106, n.1, p.27-33, Jan. 1992.

25. HEALY, T.M. The cellular reaction during carcinogenesis: variations in the numbers of mast cells, plasma cells and eosinophils. Ir. J. Med. Sci., v.144, n.7, p.255-65, July 1975.

26. HIRATSUKA, $\mathrm{H}$. et al. Multivariate analysis of occult lymph node metastasis as a prognostic indicator for patients with squamous cell carcinoma of the oral cavity. Cancer (Philad.), v.80, n.3, p.351-6, Aug. 1997.

27. HORIUCHI, K. et al. Prognostic factors for well-differentiated squamous cell carcinoma in the oral cavity with emphasis on immunohistochemical evaluation. J. Surg. Oncol., v.53, n.2, p.92-96, June 1993.

28. INTERNATIONAL UNION AGAINST CANCER. TNM classification of malignant tumours. 4.ed. Berlin, Springer-Verlag, 1987.

29. VAN DRIEL, W.J. et al. Tumor-associated eosinophilic infiltrate of cervical cancer is indicative for a less effective immune response. Hum. Path., v.27, n.9, p.904-11, Sept. 1996. 
30. JORDAN, R. C. K.; DALEY, T. Oral squamous cell carcinoma: new insights. J. Canad. dent. Ass., v.63, n.7, p.517-8; 521-5, July 1997.

31. KAPLAN, E.L.; MEIER, P. Non-parametric estimations from incomplete observations. J Amer. Statist. Ass., v.53, p.457-81, 1958.

32. KASPER, C.S.; THARP, M.D. Quantification of cutaneous mast cells using morphometric point counting and conjugated avidin stain. J. Amer. Acad. Dermat., v.16, n.2, pt.1, p.326-31, Feb. 1987.

33. KLIGERMAN, J. Estimativa da incidência e mortalidade por câncer no Brasil: introdução. Disponível na internet. http://www.inca.org.br/epidemiologia/estimativa2000/index.html. 18/03/2000.

34. KODAMA, T. et al. Large cell carcinoma of the lung associated with marked eosinophilia. A case report. Cancer (Philad.), v.54, n.10, p.2313-7, Nov. 1984.

35. KOWALSKI, L. P. et al. Factors influencing contralateral lymph node metastasis from oral carcinoma. Head Neck, v.21, p.104-10, Mar. 1999.

36. KUBO, H. et al. Cytotoxic properties of eosinophil granule major basic protein for tumor cell. Int. Arch. Allergy Immunol., v.118, n.2-4, p.426-8, Feb. 1999.

37. LAMKHIOUED, B. et al. Synthesis of cytokines by eosinophils and their regulation. Int. Arch. Allergy Immunol., v.107, n.1-3, p.122-3 May 1995.

38. LANDIS, J.R.; KOCH, G.G. The measurement of observer agreement for categorical data. Biometrics, v.33, n.1, p.159-74, Mar. 1977. 
39. LEIGHTON, S.E.J. et al. Prevalence and prognostic significance of tumor-associated tissue eosinofilia in nasopharyngeal carcinoma. Cancer (Philad.), v.77, n.3, p.43640, Feb. 1996.

40. LOOI, L. Tumor-associated tissue eosinophilia in nasopharyngeal carcinoma. A pathologic study of 422 primary and 138 metastatic tumors. Cancer (Philad.), v.59, n.3, p.466-70, Feb. 1987.

41. LOWE, D.; FLETCHER, C.D.M. Eosinophilia in squamous cell carcinoma of the oral cavity, external genitalia and anus - clinical correlations. Histopathology, v.8, n.4, p.627-32, July 1984.

42. LOWE, D.; JORIZZO, J.; HUTT, M. Tumour-associated eosinophilia: a review. J. clin. Path., v.34, n.12, p.1343-48, Dec. 1981.

43. McEWEN, B.J. Eosinophils: a review. Veter. Res. Commun., v.16, n.1, p.11-44, 1992.

44. NIELSEN, H.J. et al. Independent prognostic value of eosinophil and mast cell infiltration in colorectal cancer tissue. J. Path., v.189, n.4, p.487-95, Dec. 1999.

45. OLIVER, A. J.; HELFRICK, J.F.; GARD, D. Primary oral squamous cell carcinoma: a review of 92 cases. J. oral Maxillofac. Surg., v.54, n.8, p.949-55, Aug. 1996.

46. ONO, Y. et al. Expression of matrix metalloproteinase-1 mRNA related to tissue eosinophilia and interleukin-5 gene expression in head and neck tumour tissue. Virchows Arch., v.431, n.5, p.305-10, Nov. 1997.

47. PASTRÒÁK, A.; JANSA, P. Local eosinophilia in stroma of tumors related to prognosis. Neoplasma, v.31, n.3, p.323-6, 1984. 
48. PRETLOW, T.P. et al. Eosinophil infiltration of human colonic carcinomas as a prognostic indicator. Cancer Res., n.43, v.6, p.2997-3000, June 1983.

49. PRZEWOSKI, E. Ueber die locale Eosinophilie beim Krebs nebst Bemerkungen Über die Bedeutung der eosinophilen Zellen im Allgemeinen. Zentralblatt fur Allgemeine Pathologie und Pathologische Anatomie, v.5, p.177-91, 1896 apud THOMPSON, A.C.; BRADLEY, P.J.; GRIFFIN, N.R. ${ }^{65}$ p.469.

50. RESNICK, M.B.; WELLER, P.F. Mechanisms of eosinophil recruitment. Amer. J. Respir. Cell. mol. Biol., v.8, n.4, p.349-55, Apr. 1993.

51. ROITT, I.; BROSTOFF, J.; MALE, D. Immunology. 5.ed. Mosby, London, 1998.

52. SAMOSZUK, M. Eosinophils and human cancer. Histol. Histopathol., v.12, n.3, p.80712, July 1997.

53. SANDERSON, C.J. Interleukin-5, eosinophils and disease. Blood, v.79, n.12, p.3101-9, June 1992.

54. SANTANA, E.J.B. et al. Squamous cell carcinoma: a 20 years prevalence and descriptive analysis at the Aristides Maltez Hospital in Salvador Bahia, Brazil. Rev. Fac. Odont. Univ. Fed. Bahia, v.18, p.40-5, Jan. / June 1999.

55. SASSLER, A. M. et al. Eosinophilic infiltration in advanced laryngeal squamous cell carcinoma. Laryngoscope (St. Louis), v.105, n.104, pt.1, p.413-6, Apr. 1996.

56. SATO, M. et al. Carcinoma of the maxillary sinus with eosinophilia. Report of a case. Int. J. oral Surg., v.10, n.1, p.62-7, Feb. 1981.

57. SILBERSTEIN, D.S. Eosinophil function in health and disease. Crit. Rev. Oncol. Hematol., v. 19, n.1, p.47-77, Apr. 1995. 
58. SIMON, H.; BLASER, K. Inhibition of programmed eosinophil death: a key pathogenic event for eosinophilia? Immunol. Today, v.16, n.2, p.53-5, Feb. 1995.

59. SOUZA, A. et al. Epidemiologia do carcinoma epidermóide da mucosa bucal. Contribuição ao estudo sobre três variáveis: sexo, faixa etária e raça. Rev. Odont. UNICID, v.8, n.2, p.127-34, jul. /dez. 1996.

60. STÅHLE-BÄCKDAHL, M.; PARKS, W.C. 92-kd gelatinase is actively expressed by eosinophils and stored by neutrophils in squamous cell carcinoma. Amer. J. Path., v.142, n.4, p.995-1000, Apr. 1993.

61. STEFANINI, M. Blood and bone marrow eosinophilia in malignant tumors. Role and nature of blood and tissue eosinophil colony-stimulating factor(s) in two patients. Cancer (Philad.), v.68, n.3, p.543-8, Aug. 1991.

62. TAGA, R.; STIPP, A..C.M. Manual prático de morfometria ao microscópio óptico. Planejamento e desenvolvimento de um experimento. Bauru, FOB-USP, 1994.

63. TEPPER, R.I. The eosinophil-mediated antitumor activity of interleukin-4. J. Allergy clin. Immunol., v.94, n.6, p.1225-31, Dec. 1994.

64. TEPPER, R.I.; COFFMAN, R.L.; LEDER, P. An eosinophil-dependent mechanism for the antitumor effect of interleukin-4. Science, v.257, n.5069, p.548-51, July 1992.

65. THOMPSON, A.C.; BRADLEY, P.J.; GRIFFIN, N.R. Tumor-associated tissue eosinophilia and long-term prognosis for carcinoma of the larynx. Amer. J. Surg., v.168, n.5, p.469-71, Nov. 1994.

66. TRALONGO, V. et al. Prognostic factors in oral squamous cell carcinoma. A review of the literature. Anticancer Res., v.19, n.4C, p.3503-10, July 1999. 
67. VAN DRIEL, W.J. et al. Tumor-associated eosinophilic infiltrate of cervical cancer is indicative for a less effective immune response. Hum. Path., v.27, n.9, p.904-11, Sept. 1996.

68. VAN DRIEL, W.J. et al. Presence of an eosinophilic infiltrate in cervical squamous carcinoma results from a type 2 immune response. Gynecol. Oncol., v.74, n.2, p.188-95, Aug. 1999.

69. WARDLAW, A.J. Eosinophils in the 1990s: new perspectives on their role in health and disease. Postgrad. Med. J., v.70, n.826, Aug. 1994.

70. WARDLAW, A.J.; MOQBEL, R.; KAY, B. Eosinophils: biology and role in disease. Advanc. Immunol., v.60, p.151-266, 1995.

71. WELLER, P.F. The immunobiology of eosinophils. New Engl. J. Med., v.324, n.16, p.1110-8, Apr. 1991.

72. WELLER, P.F. Eosinophils: structure and functions. Curr. Opinion Immunol., v.6, n.1, p.85-90, Feb. 1994.

73. WONG et al. Human eosinophils express transforming growth factor $\alpha$. J. Exp. Med., v.172, n.3, p.673-81, Sept. 1990.

74. WONG, D.T.W. et al. Eosinophil ablation and tumor development. Oral Oncol., n.35, v.5, p.496-51, Sept. 1999. 


\begin{abstract}
Tissue eosinophilia as a prognostic factor in oral squamous cell carcinomas
\end{abstract}

Tumor-associated tissue eosinophilia (TATE) has been described in many sites, including head and neck. The mechanism of eosinophil attraction, and its role in tumors is not defined yet, and its presence has been related to a favorable as well as unfavorable prognosis, or even with no influence on patients outcome. Intending to verify the influence of TATE on the prognosis of squamous cell carcinomas of the tongue, oral floor, retromolar area and inferior gingiva with TNM stages II and III, 125 patients were analyzed with respect to the clinical characteristics, treatment and evolution, as well as microscopic features related to tumor morphology and invasion and the presence of the inflammatory infiltrate, with special emphasis to tissue eosinophilia, quantified through morphometrical analysis. The eosinophil count of oral squamous cell carcinomas varied from 0 to 392 per square millimeter. TATE was classified as discrete (0 to $\left.26 \mathrm{EOS} / \mathrm{mm}^{2}\right)$, moderate $\left(27\right.$ a $\left.83 \mathrm{EOS} / \mathrm{mm}^{2}\right)$ and intense (84 $\mathrm{EOS} / \mathrm{mm}^{2}$ or more) and correlated with the intensity of the mononuclear inflammatory infiltrate and with the location of the eosinophilic inflammatory infiltrate. The analysis of TATE performed by the Kaplan-Meier product-limit actuarial method and Cox proportional hazards regression model demonstrated that intense tissue eosinophilia is an independent favorable prognostic factor for squamous cell carcinomas with TNM stages II and III, located on the tongue, oral floor, retromolar area and inferior gingiva. These findings suggest a antitumoral role of eosinophils which mechanisms should be better investigated. 